THE FUTURE OF WORK

L.G. CHIOZZA MONEY: 

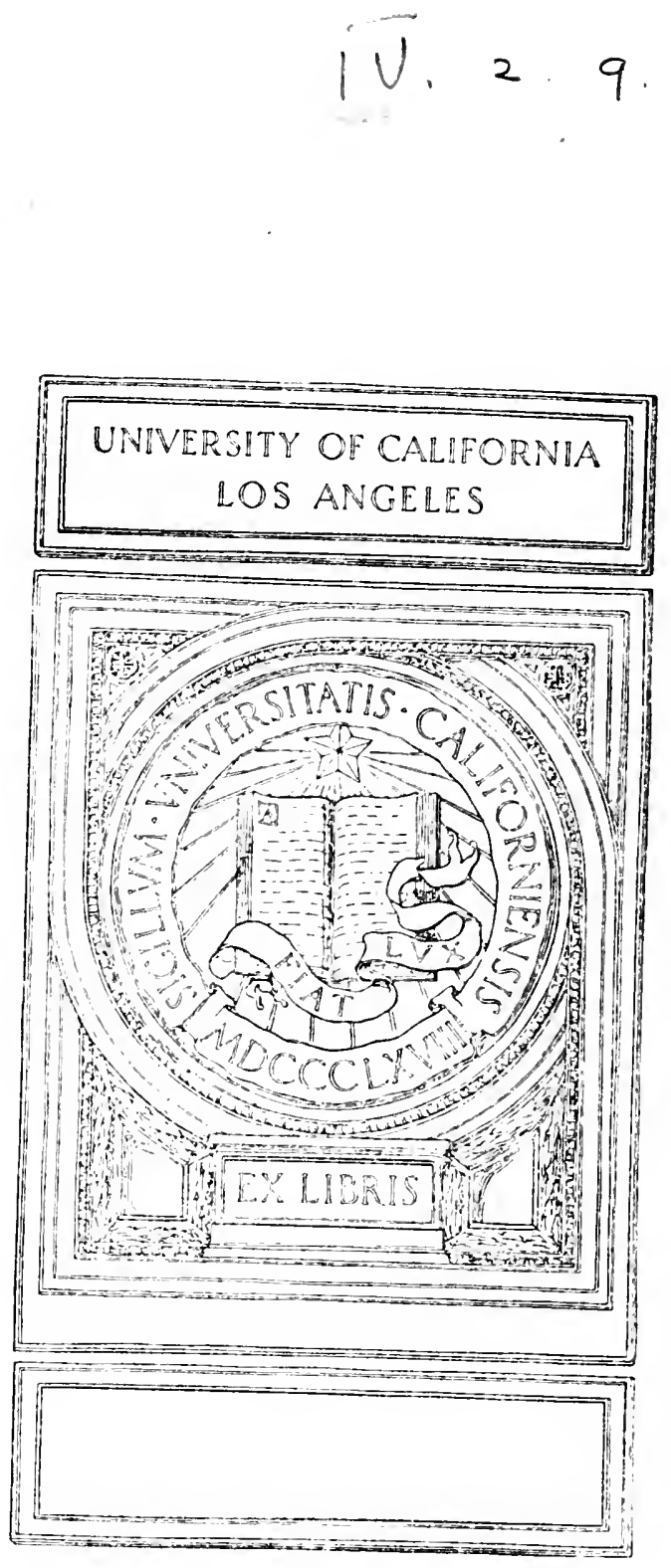


\section{,}




\section{THE FUTURE OF WORK AND OTHER ESSAYS}


SIX CENTURIES OF WORK AND WAGES

By Professor Thorold Rogers. Eleventh Edition. Demy 8vo, cloth, $10 / 6$ net.

WORK AND WAGES

Chapters from "Six Centuries of WORK AND WAGES"

Eighth Edition. Crown 8vo, cloth, $2 / 6$ net. Also a Paper Edirion, 11- net.

THE ECONOMIC OUTLOOK By Edwin Cannan, M.A.

Large crown $8 \mathrm{vo}$, cloth, 5/- net.

T. FISHER UNWIN LONDON 


\title{
THE FUTURE OF WORK
}

\author{
AND OTHER ESSAYS
}

BY

L. G. CHIOZZA MONEY, M.P.

aUthor of "RICHES AND POVERTY"

T. FISHER UN W I N

LONDON : I ADELPHI TERRACE

LEIPSIC: INSELSTRASSE 20 
First published in 1914 


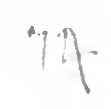

\section{PREF A CE}

is THESE essays are mainly devoted to 1 phases of the industrial problem. The paucity of output by our competitive system, 誉 after more than a century of production by power, is demonstrated, and an attempt is made to outline an industrial system calculated to yield a full harvest to Science while securing for the individual, albeit in an organised society, a maximum of personal liberty. The conception of and argument for The Great State-that the whole of the adult population should be organised to produce a high minimum standard of life, and that such organisation would yield to the whole community not only the materials of such a standard but a quality and degree of leisure and liberty at present undreamed of-have been already given to the world by a body of writers under the editorship of Mr. H. G. Wells, and part of the essay entitled "The Future of Work," which appears in this volume, has been before published. It 
is here contrasted with a study of British material output which reveals the frustration of invention by commercial method, and shows how large a proportion of the working population has its labour misdirected and poured out in waste.

It will be found of great interest to compare the studies of national expenditure and of commercial expansion which appear in these pages with the record of material production as it is. The scale of commercial operations, although it has undoubtedly extended in recent years, is still small in relation to national needs and existing powers of production, and in the time to come the world's statistics of the opening years of the twentieth century, great as they are when compared with those of fifty years ago, will undoubtedly appear exceedingly insignificant. The petty scale upon which our operations are as yet conducted, with results which yield a poor product qualified by unequal distribution, still stultifies thought and makes it difficult to prosecute reforms of any great value. The truth about our national expenditure is that, even in relation to our existing National Dividend, it is neither enormous nor alarming, and that if every penny of it were an expression of waste, it would furnish by no 
means the largest example of economic frustration which is revealed by study of our social and industrial fabric. I have dealt with this matter of proportion at some length in the essay entitled "The Road to Ruin," for I know of nothing more important than that we should bear constantly in mind that the afiairs of $46,000,000$ people, even when conducted on an inadequate scale, are necessarily expressed in large aggregates. To propose that we should spend an additional five shillings per head per annum in training our people does not sound alarming, but to vary expression and to propose the additional provision of $£ 11,500,000$ a year for the purposes of a national system of Continuation Schools is usually sufficient to end discussion on the subject, so imperfect is the power to perceive $£ 11,500,000$ as five shillings per head for $46,000,000$ heads, and to realise that it is a trifling sum in relation even to our existing inadequate income-that ineome which under any system of industry must necessarily gain by the better training of the national personnel.

Some of the essays in this volume have been before published in whole or part in various periodicals, and I should like here to express my indebtedness to the editors of "The Westminster Gazette," "The Daily News and 
Leader," "The Daily Chronicle," "The Contemporary Review," "The New Statesman," "Everyman," and "The Star," for giving them publicity.

My thanks are due to Mr. James J. Mallon, the devoted secretary of the National AntiSweating League, for kindly revising the essay on "The Minimum Wage in Practice."

L. G. Chiozza Money.

May 16, 1914. 


\section{CONTENTS}

\section{POVERTY OF PRODUCTION . $\quad$. 1}

§ 1. The Frustration of Production . 1

Small production of the modern State . . 1

The British Census of Production . . . . 1

Net output of industries . . . . . . 2

Manufacturing output in 1907 . $\quad$. $\quad$. $\quad$. 4

Agricultural production in 1908 . $\quad$. 5

Production of fisheries . . . . . . 5

Aggregate of British material production . . 6

The increment of material wealth in 1907 . 7

Distinction between material output and total National

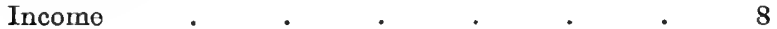

§ 2. Enumeration of Producers - 9

Number of industrial workers in $1907 . \quad . \quad 10$

Number of farm workers . . . . 10

Enumeration of British producers . . . 11

Analysis of producers by age and sex a . 12

The net product of $\$ 100$ per worker. . . 13

Analysis of net outputs in rolation to sex and ago . 14

Adult males produce much more than fl00 per head 15

\section{§ 3. British Homes and their Furnishings 15}

Paucity of production illustrated . . . 16

The production of buildings in $1907 . \quad$. 16

Tho ro-building that is needed . . 18

Building workers falling in relation to population . 19

The poor production of furnituro . . . 20

What commerce has done with science . $\quad 22$ 


\section{THE FUTURE OF WORK • .}

\section{$\S 1$. The Divorcing of Wealth and Work 24}

In the land of private officials . $\quad$. $\quad$. 24

Of consumers who are not producers . $\quad$. $\quad 25$

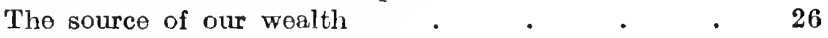

The reward of the coal-getters . $\quad$. $\quad$. $\quad$. 28

Squalor at the springs of wealth $\quad . \quad$. $\quad$. 29

\section{$\S$ 2. The Waste of Producers' Work 29}

Our few adult male producers . . . . $\quad 30$

The manufacture of competitive materials . . $\quad 31$

How printing is wasted . . . . . 31

The uses of advertisement $\quad . \quad 3 \quad$. $\quad . \quad 32$

An illustration from the boot trade . . . $\quad 33$

Competitive tea and butter . . . . $\quad$. 33

The rubbish industry $\quad . \quad$. $\quad$. $\quad$. $\quad$. 34

\section{§ 3. Science has Solved the Problem of} Poverty $\quad . \quad$ •

Plenty has been placed at our disposal . . $\quad 36$

Modern facility of production . . . . $\quad 37$

Not difficult to make but difficult to sell . $\quad 38$

How capitalists deny customers to each other $\quad 39$

The blind alley of useful work . . . 41

Few reap the full fruit of inventions . . . $\quad 42$

\section{$\S 4$. The State Organized for Work - 43}

The mischief of industrial condottieri . . . 43

Liberty and the reign of order . . . 44

The path to honourable work and honourable ease . 45

Possibility of a short working day . . . . 45

The organised work of The Great State . . 46

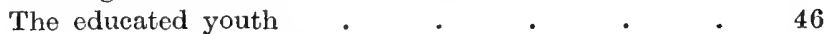

The induction into work. $\quad . \quad 5 \quad . \quad 50$

The present lack of freedom and opportunity . $\quad 50$

The professional who is also an amateur . . 51

Twenty-six million workers between eighteen and sixtyfive years of age . . . . . . 51 


\section{CONTENTS}

The conception of The Great State . . . 51

Amateur work in The Great State . . . 52

The publication of news and of opinion . $\quad 54$

An honourable conscription for the mines . . 57

No more of toil in a single groove . $\quad . \quad 58$

Collective saving $\quad . \quad$. $\quad . \quad 5 \quad 58$

The increase of really personal property $\quad$. $\quad$. 59

The absurdity of property in impersonal things . 60

The mutation of industrial processes . . $\quad$. 60

Economic independence for women . . $\quad$. 61

John Stuart Mill on concentration of industry . $\quad 62$

The American Steel Trust's gigantic undertaking . 63

Of so-called "natural monopolies" . $\quad$. $\quad$. 65

The railway and its enforced economy . $\quad$. $\quad$. 67

Economic consolidation simplifies work . . 68

How the simplicity of the Post Offico is achieved . $\quad 69$

American investigation of waste in flour distribution . $\quad 70$

An illustration from the carpet trade . . . 75

Waste in agricultural distribution . . . $\quad 78$

How we play with imported wool . . $\quad$. 79

Simplifying external trade . $\quad . \quad$. $\quad 80$

The struggle with Nature demands all Man's energies . $\quad 82$

\section{CAPITAL AND IDEAS . . $\quad 84$}

The assumption that capital is productive . 84

Professor Taussig on the alleged productiveness of

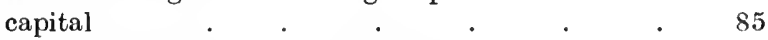

Railway versus packhorse and wagon . $\quad . \quad 86$

Ideas are productive, not the capital which embodies them . $\quad . \quad$. $\quad . \quad$. $\quad . \quad 86$

Capital cannot be conservod . $\quad$ - $\quad$. $\quad . \quad 88$

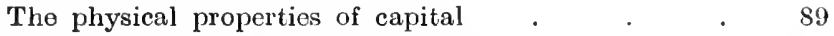

Organic reproduction and men's work. . . 90

Reproduction of inorganic embodiments of ideas . 90

Whose is the fruit of genius ? . . . . 91

The nation independent of private capitalists. $\quad 92$

\section{LAND IN RELATION TO BRITISH} WEALTH • • • • • $\quad 93$

\section{§ 1. Land and the Industrial Revolution 93}

The wealth of modern Britain not based upon land . $\quad 93$

Coal and British wealth. . . . . 94 
PAGE

Agricultural work and wealth . $\quad$. $\quad$ - 94

The coming of the Industrial Revolution . . 95

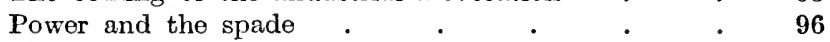

We produce one-half of the food we eat $\quad$. $\quad 97$

The advance of urban populations throughout the world 100

The real decline in male agricultural employment . 101

Check to the rural decline . . . . 103

The chief cause of rural depopulation . $\quad . \quad$. 104

The limits of British agricultural development . $\quad 106$

British land poor in materials . . . . 108

The small amount of land needed for industry . $\quad 109$

$\S 2$ 2. Space and Health • • • 112

The Industrial Revolution cannot be reversed . 112

Industrial workers must have space - . $\quad 113$

The conditions of locomotion . $\quad . \quad$. $\quad$. 113

The little land wanted for healthy life . . 114

How wo might save an army of lives every year . $\quad 114$

The need for extension of public ownership of land . 117

Land and Housing Commissioners suggested . . 117

The housing question a capital question . . 118

Civilised man needs access to capital . $\quad$. 119

\section{THE COMMON ACCUSATION • . 121}

The check on the programme girl . . . 121

The poor wages of theatre attendants. $\quad . \quad 122$

The case of the lavatory attendant . . . . 123

The free use of the cash register . . . . 124

Audited and found correct . . . . $\quad . \quad 125$

The common accusation an indictment of our society . 126

\section{THE LADDER $\quad$ • $\quad$ • $\quad$ • $\quad$ • $\quad 127$}

The conception of the Educational Ladder . 127

The sublimation of the bright boys . . . 128

Release from manual labour as an ambition . $\quad 129$

The lottery of the ladder . . . . . 131

Every child should be fully trained . . $\quad 132$

The boys wlio are trained to be serfs . . $\quad 133$

The growing perils of ignorance . . . 134

A "great broad track" for all . . . . . 135 


\section{CONTENTS}

$\S$ 1. Rural Wages as They Are . 137

Agriculture in perspective . . . . . 137

The rise in agricultural wages . . . . . 138

Agricultural earnings in 1907 . $\quad . \quad$. $\quad 140$

How agricultural wages vary . $\quad . \quad$. $\quad$. 141

How coal-based industry has affected agricultural wages $\quad 143$

\section{§ 2. Rural Wages in Relation to Prices 146}

Our prices governed by imports of oversea supplics . 146

Agricultural wages vary in spite of the general level of food prices. $. \quad . \quad . \quad . \quad . \quad 147$

Corn prices compared with agricultural wages . . 148

Agricultural wages independent of the price of food . 148

An unanswerable case for a minimum wage . . 151

\section{§ 3. Wages and Efficiency $• \quad$ • $\quad 152$}

Effect of increased wages upon the wage-earners . 152

Cheap labour is dear labour . . . . $\quad 153$

The Lancashire cotton trede . . . . 154

Wages as an element in price. . . . $\quad . \quad 155$

Wages in their effect upon the employer . . 157

The effect of factory legislation. . . . 158

High wage trades the most efficient trades . . 158

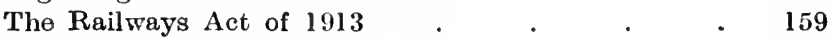

The scientific future of agriculture . . . 161

\section{$\S$ 4. A Minimum Wage in Agriculture $\cdot 162$}

Great variation in local conditions . . . . 162

Time work and picce work . . . . . 164

Some illustrations of varying conditions . . $\quad 164$

Wage Boards a suitable machinery . . . 165

Difficulties already surmounted by Wage Boards . 166

The principle of the Trade Boards Act should be applied $\quad 168$

How Wage Boards would work . . . 169

District or County Boards necessary . . . $\quad 170$

There should be a national physiological minimum . 171

Wages and Parliament . . . . 172 


\section{THE MINIMUM WAGE IN PRACTICE}

$\S$ 1. The Trade Boards Act of 1909 .

Sir Charles Dilke and the Home-Work Committee of 1907

Legislation in respect of wages "exceptionally low".

Constitution of the Trade Boards

Application to tailoring, box-making, lace-finishing, and hand chain-making . . . . 177

The Lace-finishing Board . . . . 178

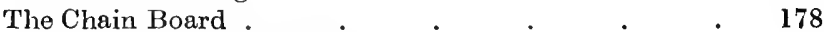

The minimum wages established $\quad . \quad$. $\quad . \quad 178$

\section{§ 2. What the Act has Accomplished • 179}

How earnings have risen at Cradley Heath . $\quad 180$

The Cradley Heath lock-out . . . . 180

Difficulties of the Nottingham lace-finishing trade . $\quad 182$

Paper-box conditions . . . $\quad . \quad$. 184

The wholesale tailoring minimum $\quad$. $\quad . \quad 185$

The case of the slow or ageing worker a $\quad$. 186

Two hundred thousand workers benefited . 187

\section{§ 3. The Extension of 1913 . $\quad$ • 187}

Confectionery, shirt-making, hollow-ware, and linen and cotton embroidery trades scheduled in $1913 \quad . \quad 187$

The failure to add calendering . $\quad$ - $\quad$. $\quad 188$

Poor wages of the women ironers $\quad . \quad 1 \quad . \quad 189$

Wages in the confectionery trades . . . 190

The poor rates paid for shirt-making . . 190

The sweating at Belfast . . . 192

The need for further extension of the Act . 193

IX. THE NEW DEARNESS • • 195

$\S$ 1. Variation of Prices since the EighTEEN-Seventies • . • • 195

The rise of prices in the last half-generation. $\quad 195$

A world-wide phenomenon . . . . 195

The new dearness in relation to protection . 196

The low level of 1896 . $\quad . \quad$. $\quad . \quad . \quad 197$

Wholesale prices, 1871-1912 . $\quad . \quad \ldots \quad$. 198 


\section{§ 2. The Gold Supply and Gold Prices}

The supply of the medium of exchange and its effect upon price . . . . . . . . 200

Prices and gold output since $1871 \quad$. $\quad . \quad 202$

The gold supply as a factor . . . . 204

The Board of Trade price numbers exarnined . 204

Price variations of certain commodities . 205

Commerce mainly conducted with credit instruments . 207

New gold and the world's stock of gold . . 208

The velocity of exchange of money . . . 209

The world's gold output, our gold imports and bankers' clearances compared . . . 210

Increased industrial consumption of gold . $\quad 210$

It is clear that the supply of gold has not been the main factor of causation

\section{§ 3. Why Prices have Risen}

211

Why prices fell in the eighteen-eighties and the eighteennineties

The creaming of the world's supplies

The modern large-scale world-exploitation . $\quad 212$

The rapid increase of demand for primary commodities 213

How demand overtook supply . . . . . 213

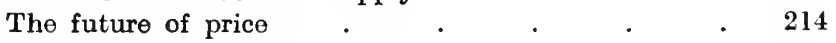

Science will probably produce an enduring cheapness . 215

\section{THE ROAD TO RUIN . . . . 216}

\section{$\S$ 1. Notes on the Rake's Progress - 216}

Down the steep path . . . . . 216

Our Jeremiahs and the facts of the case . . . 217

The recent improvement in the labour market . $\quad 219$

The rise of gross assessments to Income Tax . $\quad 221$

British exports 1895-1913 . . . . 222

The calm close of the great trade boom of 1912-13 . 223

Increase of national expenditure in nine years . $\quad 224$

Growth of national expenditure contrasted with growth of taxed incomes . $\quad . \quad$. $\quad 226$

Why the aged poor waited so long for pensions . 227

The growtl of expenditure of six great countries . $\quad 229$

National expenditure has everywhere increased of lato years 


\section{§ 2. Towards a Sense of Proportion}

The main increase in our expenditure has been upon Social Reform

Army expenditure has been stationary . . . 231

British naval expenditure for eleven years . . 232

How the rise in prices has affected naval costs. $\quad 233$

Are our defences beyond our means? . . . 234

Our expenditure on motor vehicles and battleships . $\quad 235$

Some striking comparisons . . . . . 235

The scale of our affairs . $\quad$. $\quad . \quad 2 \quad . \quad 236$

The small affairs of a great people are large in the aggregate . .237

The cost of a starvation diet for forty-six million people $\quad 239$

The cost of housing nine million families . . 240

The cost of improving education . . . 240

\section{§ 3. National Expenditure and Economic} Stability $\quad \cdot \quad \cdot \quad \cdot \quad \cdot \quad \cdot 241$

The sad case of our poor taxpayers . . . 241

Some typical income-tax burdens . . . $\quad 242$

Peace, Retrenchment, and Reform . . . 243

Keeping the Government poor . . . . $\quad \mathbf{2 4 4}$

How distress accompanied a starved revenue. $\quad 245$

Taxation has not touched the fringe of luxurious expenditure . . . . . . . $\quad$. 246

Increased national expenditure has made for economic stability . . . . . .

\section{TARIFF REFORM-TEN YEARS} AFTER

$\S 1$. Mr. Chamberlain's Case and the ACCOMPlished Facts $\quad$. $\quad$. 248

The suggested bargaining with the Colonies . . 249

Lineal descent from mercantilism . . . 249

Why food was to be taxed . . . . $\quad 250$

The concrete proposals of $1903 \quad$. $\quad . \quad 251$

Small but costly tares . . . . . . 252

Our increasing wheat imports from the Colonies . 255

Record of the threatened industries . . . $\quad 257$

The insuperable difficulty of distinguishing between materials and manufactures . . . 261 
§ 2. The Later Developments of Tariff

REFORM . • • $\quad . \quad$. 262

Britain's two great gifts . $\quad . \quad$. $\quad . \quad . \quad 262$

A common tariff impossible for the British Empire . 263

Free Trade the only possible fiscal basis for a British Imperial Union

How the Tariff " Commission" dealt with Mr. Chamber-

lain's food programme . . . . . 265

Sir Edward Carson on the taxation of Colonial products 265

The shifting policy of Tariff Reformers . . 268

The desertion of the British farmer . . . 271

The Edinburgh programme of January 1913 . . 271

Contradictory offers to the Colonies and to the British workmen . . . . . . . 273

Value of Free Trade to the British Empire 274

XII. THE SINGLE TAX • • • • $\quad 276$

$\S$ 1. The Single Tax Statistically Im-

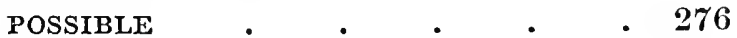

The theory that the land of a country is the sole source of its wealth . . . . .

Quesnay the physiocrat could not foresee the Industrial Revolution . . . . . . 277

The estimate of British land rents . . . 279

The Single Taxers' exaggeration of British land values 280

Rent compared with the National Income . . 282

Analysis of property passing at death in 1912 . 283

\section{§ 2. Some General Considerations . 284}

What British wealth is built on . . . 284

British land yields little $\quad . \quad$. $\quad . \quad 285$

Why British agricultural rents are low . . 286

The taxation of Land Values . . . . . $\quad 287$

Taxing the wrong people . . . . 288

Hard case of mortgagors under the Single Tax . 289

The Single Tax the enemy of city amenities. . 290

Application to Local Taxation . . . . 291

Untaxing improvements $\quad . \quad . \quad . \quad . \quad 292$

The Single Tax and tho use of land . . . $\quad 293$

The Single Tax would not cheapen land . . 294

Henry George on the Single Tax ideal . . 294

\section{INDEX}





\section{THE \\ FUTURE OF WORK}

I

\section{POVERTY OF PRODUCTION}

\section{$\S$ 1. The Frustration of Production}

$\mathbf{W}^{\mathrm{E}}$ commonly entertain such exaggerated ideas of the production of wealth in our time that it is difficult to realise that the truth about a modern industrial State is that, although it has been armed by Science with extraordinary powers of production, it produces little. The little that is produced is distributed very unequally, and the net result is a community of poor people veneered with a thin layer of the well-to-do. To make this statement complete as a broad generalisation of the facts, it is necessary to add that no small proportion of what production there is consists either of rubbish or of things that had better not be made.

The results of the first British Census of Production, made in accordance with the 
provisions of the timid and inadequate Census of Production Act of 1906, enable us to state the condition of British production in almost precise terms. Agriculture was specifically excluded from the Census of Production Act, but the Board of Agriculture made a voluntary census of the agricultural output for the year 1908, and the work was done so well that we are able to add its results with some confidence to the aggregates of the compulsory Production Census.

Fortunately, in calculating the value of the production of British mines, mills, factories, and workshops, the Board of Trade, in carrying out the Census work, gave us not merely the gross value of the products of each trade. The gross value of the production of any industry is not due entirely to the efforts of that industry. Materials are bought and worked upon, and what any industry adds to the wealth of the country is truly to be tested, not by the value of its output, but by the value which it adds to the materials which it uses. This value, the Board of Trade, in their report on the Census of Production, term the "net output." If this net output had not been ascertained for each trade, it is obvious that there would be a very large element of duplication in the totals 


\section{FRUSTRATION OF PRODUCTION 3}

arrived at. If we took the gross outputs of all our industries and added them together, we should be valuing many elements of production over and over again. Take coal as an example. The value of coal produced from British mines appears in the Census first under Coal. Some of this coal is used to smelt iron, and the value of this coal, therefore, again appears as Iron. The iron becomes a finished iron product, and the coal value appears again, perhaps more than once. One of these products, say a boiler plate, may again appear in the value of Ships. So $£ 1$ worth of coal may appear twice, thrice, or more times if we simply make an aggregate of the gross productions of all industries. By obtaining the "net product" of each industry, however, the element of duplication is entirely avoided.

The Board of Trade ascertained that the firms making returns had a gross output averaged at $£ 1,765,366,000$. The firms having these outputs, however, used materials valued at $£ 1,028,346,000$, and they gave work out to other firms valued at $£ 24,885,000$. The net industrial output of the United Kingdom, therefore, as revealed by the Census of Production, amounted to $\mathfrak{f} 712,135,000$. It is well to set out here the particulars for each 
of the great groups of trades as analysed by the Census :

United Kingdom IndUstrial OUTPUT, 1907

\begin{tabular}{|c|c|c|c|}
\hline Group of Trades. & $\begin{array}{l}\text { (1) } \\
\text { Gross Output } \\
\text { Factory Value. }\end{array}$ & $\begin{array}{l}\text { (2) } \\
\text { Materials Used } \\
\text { and Work Given } \\
\text { Out. }\end{array}$ & $\begin{array}{c}\text { (3) } \\
\text { Net Output : } \\
\text { Col. (1) minus } \\
\text { Ool. (2). }\end{array}$ \\
\hline Mines and Quarries & $\stackrel{£}{£} 148,026,000$ & 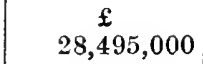 & $\stackrel{f}{\stackrel{f}{119,531,000}}$ \\
\hline $\begin{array}{l}\text { Iron and Steel, Engi- } \\
\text { neering and Ship- } \\
\text { building }\end{array}$ & & & \\
\hline $\begin{array}{c}\text { building } \\
\text { Metal Trades }\end{array}$ & $375,196,000$ & $222,114,000$ & $153,082,000$ \\
\hline $\begin{array}{l}\text { letal Trades } \\
\text { extile Trades }\end{array}$ & $93,465,000$ & 81,572 & $11,893,000$ \\
\hline $\begin{array}{l}\text { Textile Trades } \\
\text { Clothing Trades }\end{array}$ & $333,561,000$ & $239,227,000$ & $94,334,000$ \\
\hline $\begin{array}{l}\text { Clothing Trades } \\
\text { Food, Drinkand Tobaceo }\end{array}$ & $107,983,000$ & $60,310,000$ & $47,673,000$ \\
\hline $\begin{array}{l}\text { Food, Drink and Tobacco } \\
\text { Chemical and Allied }\end{array}$ & $287,446,000$ & $197,932,000$ & $89,514,000$ \\
\hline $\begin{array}{c}\text { Chemical and Allied } \\
\text { Trades }\end{array}$ & & & \\
\hline Paper, Printing and & & & 00 \\
\hline $\begin{array}{l}\text { Stationery } \\
\text { eather, Canvas }\end{array}$ & $61,308,000$ & $27,658,000$ & $33,650,000$ \\
\hline Indiarubber. & 00 & 26,3 & 000 \\
\hline Timber Trades & $46,390,000$ & $24,946,000$ & $21,444,000$ \\
\hline Clay, Stone, Building, and & & & \\
\hline Contracting Trades & $116,692,000$ & $56,236,000$ & $60,456,000$ \\
\hline Miscellaneous Trades . & $8,288,000$ & $3,845,000$ & $4,443,000$ \\
\hline Public Utility Services & $77,051,000$ & $31,111,000$ & $45,940,000$ \\
\hline Total & $\mathfrak{f 1}, 765,366,000$ & $£ 1,053,231,000$ & $£ 712,135,000$ \\
\hline
\end{tabular}

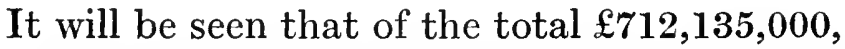
as much as $£ 119,531,000$ is the net output of mining and quarrying, chiefly, of course, coal mining. Apart from mining and quarrying, therefore, the net output of British industries in 1907 was worth $£ 592,604,000$. It is a small total for a nation of $46,000,000$ people. Is it complete? 'The answer is that it is so nearly 


\section{FRUSTRATION OF PRODUCTION 5}

complete that the Board of Trade think $\mathfrak{\$ 0 , 0 0 0 , 0 0 0}$ a sufficient estimate of the output of about $1,000,000$ industrial workers excluded from the Census chiefly because they were working on their own account.

Now for Agriculture. The Board of Agriculture and Fisheries estimate, as the result of their inquiries, that in 1908 the produce of British agriculture was worth $£ 210,000,000$ at points of production, made up as follows :

United Kingdoni Agricultural Production

Value at Farms.

£

Food and Fodder Products, Flowers, Seeds and Plants

Horses and animals not for food .

Hides and Skins

Wool

Timber

Flax

$$
\begin{array}{r}
195,700,000 \\
3,400,000 \\
6,000,000 \\
3,600,000 \\
900,000 \\
400,000 \\
\hline £ 210,000,000 \\
\hline
\end{array}
$$

TotaL

In this total of $£ 210,000,000$ all duplication is avoided. The United Kingdom is considered as one farm. For example, when turnips are not sold off a farm, but eaten by animals and turned into meat or milk, the value of the turnips appears in the value of the meat or milk. As to British fisheries, the yearly output is estimated at about $£ 12,000,000$. We get, therefore, as the aggre- 
gate of British production of all kinds for 1907, the following round figures:

\section{British Material Production in 1907}

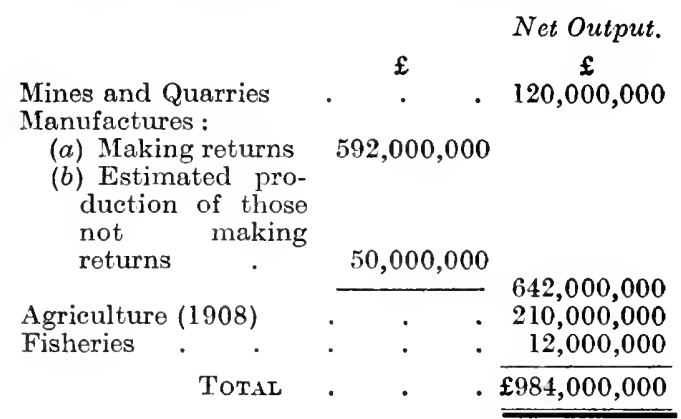

Such was the extent of British material production in 1907. The net product was $£ 984,000,000$, and if we add the value of imported materials used by manufacturers, and the manufacturers' costs of obtaining those materials, we arrive at about $£ 1,450,000,000$ as the value of material commodities at points of production in 1907. A considerable proportion of this was exported, and a certain amount of stuff ready for consumption was imported.

If we desire to ascertain what was the net gain in material wealth of the United Kingdom in 1907 , we have to consider the net output figures in relation to imports and exports, and we get the following result: 


\section{FRUSTRATION OF PRODUCTION 7}

United Kingdom Increment of Material Wealth in 1907

$\mathfrak{f}$

Net Material Production as given

in last table . $\quad . \quad 984,000,000$

Add Imports into United Kingdom $646,000,000$

Subtract :

$\mathfrak{E}$

$1,630,000,000$

(1) Exports of British production

(2) Exports of im-

ported goods $\quad 92,000,000$

$426,000,000$

$518,000,000$

Result: Net gain of material wealth in 1907

. $£ 1,112,000,000$

Thus, at "place of production" prices, before the host of distributive agents largely raised the values by some necessary and much unnecessary work, the material commodities gained by the work of a population which in 1907 numbered 44,000,000, amounted to no more than $£ 1,112,000,000$, or just over $£ 25$ per head of the population. We see very clearly that, unequal as the distribution of wealth actually is, British poverty is by no means a matter of ill-distribution alone. To leave out of account the important factor that no small part of this material income is needed for public and not for individual purposes, if we imagine the $£ 1,112,000,000$ worth of commodities divided equally amongst our forty-six millions of pcople, it would not suffice to give good food and good clothing 
and good housing, to say nothing of the materials of amusement, of sport, of culture, and of travel. It is only too clear that we have not yet attained to a degree of production large enough to confer more than a very modest standard of comfort upon our great population. We have just enough to abolish poverty in its worst sense.

The figure quoted is not, of course, the same thing as the figure representing the aggregate of the incomes of the individuals composing the United Kingdom. The aggregate of incomes is about twice as great as the total we have just considered-the National Dividend is certainly not less than $£ 2,100,000,000$ in 1914-but it is made up of the valuation, not only of material things, but of all sorts and kinds of services, useful and useless, social and anti-social. It includes, of course, the extraordinary costs of distribution, amounting to $£ 400,000,000-£ 500,000,000$, which stand between producer and consumer, and are so considerable an element in the causation of poverty. 


\section{ENUMERATION OF PRODUCERS 9}

\section{§ 2. Enumeration of Producers}

Let us pass from the production to the persons who produce. The facts relating to employment revealed by the Census of Production have not yet received the attention which is their due, and we shall do well to look at them closely. The employment figures revealed by the Production Census are very much more valuable than those of the Population Census. We have not yet an analysis of the Census of 1911 for the three Kingdoms, but if we had, we should not have such valuable material before us as that which is yielded by the inquiry under examination. When persons are asked to name their occupation for the purpose of a population Census, we obtain a considerable proportion of worthless replies. People past work, and indeed no longer working, often describe themselves as following their old occupations. Those unemployed, those sick or injured, are also included as workers at work. The Census of Production, on the other hand, gives us the number of persons actually at work. It is not quite complete, for the reason already stated, and the Board of Trade estimate that about $1,000,000$ persons-persons working on 
their own account, and so forth-were not included in the employers' schedules.

The actual returns showed that in 1907 the firms reporting employed as nearly as possible $7,000,000$ people, of whom about $6,500,000$ were wage-earners and about 500,000 salaried persons. To these, as already noted, we have to add 1,000,000 for the unscheduled. It remains to consider agriculture. Including the "occupiers" themselves, some of them farmers and farmers' relatives stated to be assisting in production, the Board of Agriculture's returns show that the United Kingdom has about 2,800,000 persons of both sexes engaged in agriculture. It is indisputable, however, that a certain proportion of the "occupiers" are by no means following agriculture as their profession, and as to the relatives, and especially the female relatives, returned as working on the farms, the return of a unit does not, in a large number of cases, represent a constant and regular producer. It is probable, therefore, that 2,500,000 is a liberal estimate of the number of persons actually and regularly engaged in agricultural production. The total number of producers in the United Kingdom in 1907 was therefore roundly as follows (neglecting fishermen, whose numbers are relatively small) : 


\section{ENUMERATION OF PRODUCERS 11}

Brimsh Producers (Direct Producers of Material

Comodities) circa 1907

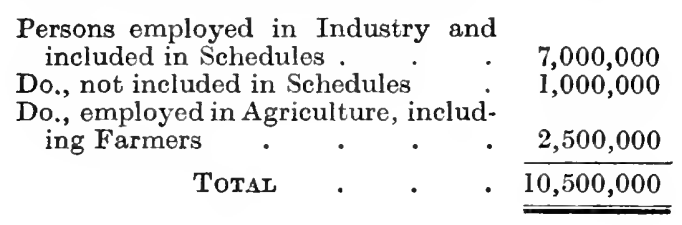

Such is the number of men, women, boys, and girls engaged in material production in the United Kingdom. To judge by the Census of 1901, and the subsequent increase of population, we have about 20,000,000 persons of all sexes and ages who, in Census terminology, are engaged in occupations for gain. Therefore, about one-half of our occupied population is engaged in material production. It is a thing most remarkable. I do not lose sight of the fact that of the balance of rather less than 10,000,000 persons who are not engaged in material production, a certain proportion is usefully employed in contributing indirectly to production. Indeed, the railway man who helps to move a manufactured article from Coventry to London is as much a producer of wealth as a mechanic engaged in a motor-car works at Coventry. But when we make every allowance for such considerations, it remains most significant that one-half of the British population working 
for gain is divorced from direct material production.

And when we analyse the $10,500,000$ who are direct producers, the number looks even more unsatisfactory. It will be remembered that 1,000,000 of them consist of an estimate of the mostly inefficient people not included in the schedules, so that we have $9,500,000$ scheduled persons to subject to analysis. Of these, 2,500,000 are agricultural workers, and chiefly adults. The $7,000,000$ industrial workers are made up, in round figures, as follows :

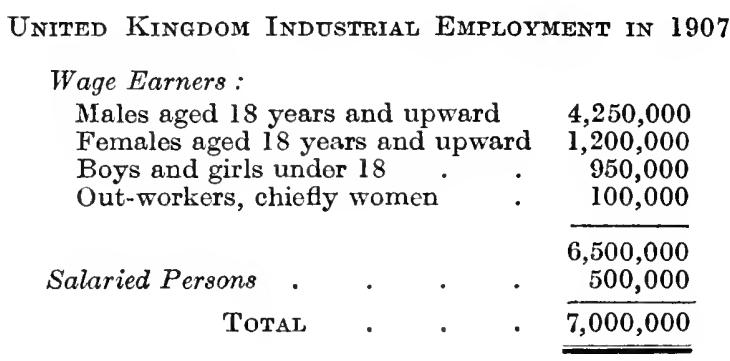

We see, therefore, that in our great population-which, in 1914, is about 46,000,000, and which in 1907 was as nearly as possible $44,000,000$ (observe in passing how emigration has reduced the rate of increase of our population)-there were in 1907 only $4,250,000$ men, counting as a "man" a male person 


\section{ENUMERATION OF PRODUCERS 13}

aged eighteen years and over, engaged in mining or quarrying or manufacturing, and of these about one million are miners and quarrymen. Our male population eighteen years of age and upwards numbered about 13,000,000. So we get the striking fact that of our male population aged eighteen years and over, only about one in three is engaged directly in producing industrial wealth.

The fact that $7,000,000$ industrial workers have a net output of no more than $£ 700,000,000$ or so has been eagerly seized upon by those who oppose the aspirations of Labour. We find them dividing $£ 700,000,000$ by $7,000,000$ to arrive at the brilliant if simple conclusion that the net output per British industrial worker is no more than $£ 100$. Further, it is pointed out, the $£ 100$ per worker per head is the total sum out of which has to be paid not only the remuneration of the worker, but the remuneration of every other interest concerned. Rent, interest, profit, etc., all have to come out of the $£ 100$. And so you arrive at the mournful conclusion that the payment of even a thirty-shillings minimum wage is in practice impossible.

But the 7,000,000 workers do not consist of men only. Mr. A. W. Flux, the Director of the Census of Production, has made a 


\section{POVERTY OF PRODUCTION}

classification of the $6,500,000$ manual workers, and here it is :

Analysis of Net Outputs in Relation to Sex and Age

\begin{tabular}{|c|c|c|c|c|}
\hline$\Delta$ verage Net $O$ & pu & Head. & $\begin{array}{c}\text { A. } \\
\text { Men } \\
\text { (Males over 18). }\end{array}$ & $\begin{array}{c}\text { B. } \\
\text { Women, } \\
\text { Boys and Girls. }\end{array}$ \\
\hline $\begin{array}{l}\text { Under } £ 50 \\
£ 50-£ 75 \\
£ 75-£ 100 . \\
£ 100-£ 125 \\
£ 125-£ 150 \\
£ 150-£ 175 \\
£ 175-£ 200 \\
£ 200 \text { and over }\end{array}$ & . & $\begin{array}{l}\dot{.} \\
\dot{.} \\
\dot{.} \\
\dot{.}\end{array}$ & $\begin{array}{r}9,481 \\
511,915 \\
1,337,898 \\
1,055,742 \\
831,132 \\
65,092 \\
138,635 \\
230,963\end{array}$ & $\begin{array}{r}23,132 \\
996,412 \\
806,338 \\
297,749 \\
84,159 \\
' 50,373 \\
26,195 \\
13,578\end{array}$ \\
\hline & & & $4,180,858$ & $2,297,936$ \\
\hline
\end{tabular}

We see that the $£ 100$ per worker is the average of many inequalities. Take the first line: trades in which the net output is under £50. The people working in it are 23,132 women, boys, and girls, and only 9,481 men. Or look at the next line: output $£ 50$ and

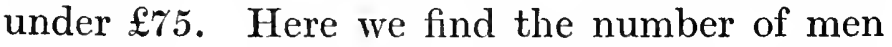
(males over eighteen) only 511,915, whereas the women, boys, and girls amount to nearly 1,000,000. Even in the next line, output $£ 75$ and under $£ 100$, there are no less than 806,338 women, boys, and girls, against a little over $1,300,000$ men.

As soon as we get over the $£ 100$ point we see that the men are in the majority. So 


\section{ENUMERATION OF PRODUCERS 15}

that the net output of adult male industrial workers in this country is much over $£ 100$, although we do not know precisely what it is.

There is thus nothing in the results of the Census of Production that leads us to believe that a much greater remuneration for labour is not possible, even with production as it is. But it is the essence of the theory of high wages that they lead to a better production through improving the efficiency of both master and man, and through enlarging markets by increasing purchasing power, and this even in a competitive society. That is to say, workmen ought to get more than they do out of the existing production-the frustrated production of competitive industry. That is a question quite apart from what they might receive under a system of orderly, scientific production.

\section{$\S$ 3. British Homes and their Furnishings}

If analysis shows British production to be small, and the number of persons engaged directly in the production of material commodities to be inadequate, what appears when 
we relate the production of any industry to the needs of our population? Let me illustrate this important point by reference to two trades of the first importance, the first the building and repairing of the homes of the people, the second the furnishing of the homes of the people. As to these we can get a great deal of light from the Census of Production.

We find that in 1907, which, it will be remembered, was a "boom" year, the production or repair of buildings of all sorts, whether private residences or trade or business premises, amounted to $£ 73,000,000$. Further analysis shows that this $£ 73,000,000$ was made up as follows : Construction of new buildings, about $£ 44,000,000$; Alteration and repair of existing buildings, about $£ 29,000,000$. Let us consider these figures in relation to the needs of the nation.

First let us consider the expenditure upon alterations and repairs- $£ 29,000,000$. This is all that was spent in 1907 upon the alteration, repair, and redecoration of over $9,000,000$ private houses and trade premises, including mills, factories, warehouses, shops, etc. It covers all the many trades concerned with alterations and repairs, including painting, whitewashing, paperhanging, plumbing, etc. 


\section{BRITISH HOMES}

The average bill for repair and redecoration for each building was little more than $£ 3$, and those who have had the pleasure of encountering bills of the kind will know how little of such work is covered by $£ 3$. If we did not know the houses and trade premises of the United Kingdom, we could gather from these figures that our $9,000,000$ buildings cannot be in very good repair, and observation of houses as they are confirms only too closely the results of the Production Census.

The remainder of the aggregate, $£ 44,000,000$, represents new building construction, and it comes to less than $19 \mathrm{~s}$. per head of the population. This sum was not spent upon new private dwelling-houses. We have again to remind ourselves that it covers every sort and kind of premises, whether used for private or public purposes, or for trade or industry. It is not too much to say that our great towns contain tens of miles of filthy brickwork ripe for demolition. Some tenement houses recently tumbled down in Dublin and killed some of their unfortunate inhabitants. It is not long since a great London railway-terminus fell to pieces like a house of cards. It can only be said that it is surprising that such things do not happen more frequently, when we think of the condition of many of our 
railway-stations, trade premises, and dirty tenement houses. All that we are doing to eradicate the houses which kill tens of thousands of our people every year, and which deprive hundreds of thousands of health, is to advance to a better condition of housing at the rate of an expenditure represented by 19s. per head per annum, that sum covering every sort and kind of new building. The probable expenditure on new dwelling-houses is $8 s$. or $9 s$. per annum per head of the population!

It will help us to form an idea of the inadequacy of the present rate of re-building if we consider what it would cost if we built only 200,000 new houses every year. Let us imagine that we spent upon them $£ 400$ apiece-a sum which goes a very little way in giving comfort to a family. Yet 200,000 houses at $£ 400$ each comes to $£ 80,000,000$, and we are spending as little as $£ 44,000,000$ a year upon every sort and kind of new building.

Hard upon the publication of the Final Report of the Census of Production of 1907 followed the first Report upon Unemployment Insurance. What did it show us? It showed that the Government actuary who drew up the estimate of the number of 
builders' men who would come within the provisions of the Unemployment Section of the National Insurance Act, working, as he had to work, upon the latest Census available to him-that of 1901-estimated that $1,321,000$ persons would be compulsorily insured as belonging to the group of building trades. The estimate was for 1912. The actual results of the working of the Act show that in 1913, instead of there being $1,321,000$ builders, there were $1,109,953$. So that, relatively to population, the number of builders has been falling off, which means in relation to population a decrease of production of material commodities of an especially important kind.

I pass from houses to the eontents of houses. The Census of Production shows us what the United Kingdom produces by way of an addition to the stock of furniture. The schedules received from the factories and workshops making furniture, house furnishings, office and shop fittings, bedding, cabinet and upholstery work, etc., show that the output in 1907 of finished articles of this kind was as shown on the following page.

There is not a great import or export trade in furniture, and broadly we may take what imports and exports there are to balance each 


\section{POVERTY OF PRODUCTION}

other and consider the figure given as representing the consumption of furniture in the United Kingdom in 1907 at wholesale prices. Retail prices would be about one-third higher. The production of furniture is seen to be as inadequate as, or more inadequate than, the production of houses. Of wooden furniture the factory value of the output was no

Furniture, House Furnishings, and Upholstery Production in 1907

\begin{tabular}{|c|c|}
\hline \multirow[b]{2}{*}{ Furniture of wood, upholstered or not } & \\
\hline & $7,449,000$ \\
\hline House furnishings not elsewhere specified & $6,027,000$ \\
\hline Bedding, cushions, etc. & $1,471,000$ \\
\hline Fittings forshops, offices, banks, & \\
\hline ships & $1,126,000$ \\
\hline Blinds & 554,000 \\
\hline Wire mattresses & 161,000 \\
\hline $\begin{array}{l}\text { Bamboo, basket, and wicker furniture } \\
\text { (including perambulators) }\end{array}$ & \\
\hline Other products not furniture or furnishings & 158 \\
\hline TOtaL VALUE OF ABOVE & $£ 17,036,000$ \\
\hline
\end{tabular}

more than $£ 7,500,000$--say $£ 9,000,000$ retail value-and this poor amount of stuff was all that was commanded by about $44,000,000$ people. It comes to about $4 s$. per head per annum, or a little more than $\mathfrak{f 1}$ per family. We see that what ought to be a magnificent trade-a trade of dimensions large enough to employ an army of skilled workmen-is in fact a small and struggling industry. A great deal of the furniture which is made is rubbish. I took the trouble to 
go round a recent Furniture Exhibition at Olympia, and I can only describe the impression the stuff made upon my mind as painful. The greater part of the exhibits consisted of vulgar trash. There can be no doubt that the wooden furniture total would be far less than it is but for the practice of the hire system, which enables poor people to acquire rubbish at a high price from what are, in effect, moneylenders.

The examples I have given could be multiplied a hundredfold. It is possible to demonstrate in relation to almost every sort and kind of manufactured commodity that industry has not yet learned how to supply a great nation with an adequate supply of material things. The home market is everywhere revealed as a thing of small dimensions, which it needs but a very small production to glut.

It is a great reproach to our civilisation and to our organisation for work that the great ideas of the inventors, and the magnificent endowment which modern science has bestowed upon us, yields so little. It is clearly not the fault of industrial powers per se. The powers exist. Mankind possesses to-day an extraordinary command of the forces of Nature. We are no longer the helpless creatures we were 150 years ago. Then, poverty 
was a natural poverty, for men had necessarily to earn their bread by the sweat of their brows and to devote themselves almost entirely to work upon the land, done without the assistance of any but primitive instruments. That is not our case to-day. Agriculture no longer demands the arduous labour of the majority of men in a white civilisation, and the labours of the majority are set free to apply scientific methods to materials to produce the numerous commodities which lift Man above the condition of the agricultural hind.

Those who advance proposals for the better ordering of the affairs of a State, are usually met with the cry, "You would destroy the production of wealth; you would pull down the magnificent edifice which has been built up." The truth is that it is the commercial system, and not any new proposal, which is on its defence. What Commercialism has to answer is this: "What have you done with the ideas of great men; what have you accomplished with the weapons of Science; what have you to show in actual, practical production in 1914, 145 years after James Watt took out his steam-engine patent, 85 years after George Stephenson ran his 'Rocket' in the Rainhill competition, 82 years after Faraday discovered magneto-electric induc- 
tion ?" The critic possessing knowledge of the magnificent aids to production now placed freely in the hands of the commercial man (I say freely, for the great mass of ideas is unprotected by patents, and in any case the term of a patent is usually fourteen years) is entitled to demand an explanation of the results of the Census of Production. He asserts that the record is one not of success, but of ignominious failure; he alleges that a nation organised for work could, wielding the weapons of Science, produce much more wealth with much less labour, and the gravamen of his charge against commercialism is that since man possesses the means of adequate wealth production, poverty has become a crime. 


\section{II}

\section{THE FUTURE OF WORK}

$\S$ 1. The Divorcing of Wealth and Work

TT was a wise old woman who sat her down 1 in Cheapside and waited for the crowd to go by. To the average London citizen she is a perfect picture of the ill-informed, rural intelligence. To the man who understands, she had good cause to contemplate the stream of passers-by with amazement, and to expect it to cease. What, indeed, are all the people doing who may be seen thronging the streets of the City of London?

It is not difficult to answer this question in a negative sense. Observation shows us that, almost in its entirety, the ceaselessly moving City crowd is composed of non-producers. The centre of London is fed from about 7.30 a.m., the hour at which workmen's trains cease to run, until about 11 o'clock, with tens of thousands of men and women, and boys and girls, who are not merely non-producers, but persons who could not give you an intelligent 
idea as to how any useful material thing is made. 'Whether our point of observation be the Mansion House, or the top of Ludgate Hill, or westwards at the Marble Arch, it is rarely that there pass before the vision the dirty clothes which, in England, we are unhappily accustomed to regard as the proper costume of a working man. We are in a land of "officials," where an enormous number of people are traffickers in material commodities, who eat without sowing or reaping, who dress without spinning or weaving, who house themselves without building or planning. From merchant to clerk, from shopkeeper to girl typist, from stockbroker to commission agent, from banker to office boy, from lawyer to doorkeeper, it is a land in which an army of people consumes without producing.

Traced homewards, the individuals who form the City stream may be found living in places widely remote, from rows of little houses in Tooting or Walthamstow, to expensive and hardly less ugly red-brick villas in Hendon or Woking, in Hampstead or Surbiton. There spending the big and little incomes which they gain by non-productive work, they support by their expenditure, to build and repair their homes, to sustain and bcautify their persons, a very large proportion of the 
inhabitants of London, and of Greater London, and of the places immediately beyond.

Not all the latter are non-producers. Apart from the shopkeepers and their assistants, and the menial servants, there are brought into the economic chain a considerable number of nominally useful producers who spend their work at the bidding of the non-producers who traffic at the centre.

The result, in large, is to bring into the Metropolis and its surroundings imports of material commodities which have been either created in those parts of the country where men work usefully, or which have been gained by commerce from abroad. It is not forgotten that London is itself a manufacturing centre-are not even food factories to be found in the filthy abysses of the East?-but the matter may be put in true perspective by pointing out that the London County Council area contains only 387,000 manual workers in a population of $4,523,000$.

It is a far cry from the place of central traffic and private officialdom to the springs of British wealth. British prosperity is built upon the possession of one of the greatest and richest coal areas in the world, and the British coal mines are not situate near London. They are to be found in the West, and in the Mid- 
lands, and in the North. Curiously, there are not so many red-brick villas near the springs of work as there are near the centres of mere traffic. You shall seek in vain in Cardiff or in Newcastle for endless streams of real and imitation swells. Mean and sordid, even as measured by the standard of a sordid Metropolis, are the highways and byways of the places from which flow the mineral streams which have done so much for Britain.

It was the unlocking of the British coal seams which made modern Britain-which in a period of a century and a half changed a small, poor, backward and stagnant nation into a great manufacturing State, with a population whose capital and its immediate environs to-day contain a larger population than that of the whole of England and Wales in the middle of the eighteenth century. The use of coal having entirely changed the character of British industry and trade, and made the United Kingdom great and in the ordinary sense prosperous, it might be imagined that the lesson would be so surely learned, especially seeing that coal-getting is arduous and exceedingly dangerous, that mining would rank amongst the most honoured of callings, and that mining districts would flow with the milk and honey bestowed by a grateful people upon 
the indispensable creators of wealth. In reality, the mining districts of the United Kingdom are devoid of every trace of beauty, and of nearly every rational means of happiness. Take, for example, the unique South Wales coalfield, and its unhappy valleys. Perched on the hillsides, in close contiguity to the pit head, gloomy rows of uncomfortable boxes shelter those who work and die to produce a little for themselves and a great deal for the soft-handed ones who dwell afar off. Once-smiling valleys have been shorn of every natural attribute and changed into pandemoniums of work and pain. Even a mining manager in one of these little Welsh villagesand how few can hope to rise to become mining managers-lives in a small and obscure house where the delight of a garden is unknown. So melancholy is the impression created by these places that one discovers almost with surprise that the people have not lost their gift of song.

Wherever the coal is found, whether it be in Scotland, or in the Black Country, or in Yorkshire, or in Northumberland, or in Lancashire, there also the greater part of useful British industrial work is done, and there also, strangely, are to be found the chief evidences of an all-pervading poverty. The nearer the 
source of wealth, the nearer the abodes of squalor. The nearer to honourable, useful, and necessary labour, the nearer to desolation. Who that has seen the purlieus of our industrial towns, and who understands that these are the places where the greater part of the material wealth of the country is created, can fail to wonder why so few commodities remain with those whose life is spent in productive labour?

It would astonish me to learn that the majority of the readers of these words reached this point without feeling an ardent desire to remind the author of the fact that a man or woman who does not work with his hands, in the direct production of material commodities, is not necessarily a non-producer. I therefore hasten to add that I am very familiar with the fact, and with all that has been said about it by the long line of economists, and that I shall discuss it hereafter.

\section{§ 2. The Waste of Producers' Work}

Because so many of us are wasting our time, the matcrial production of the United Kingdom is not large cnough, even if equally 
distributed, to redeem us from poverty. In the mean state that is, the waste of work is so grievous that it is but the minority of the working population which is engaged in material production, and even as to that minority it is most unhappily true that it is largely engaged in making material things which ought not to be produced at all-things which the Great State of our dreams would ban as economic indecencies.

We have seen, in our study of poverty of production, how small a crop is at present produced by commerce from the seed furnished by science, and that in 1907 our great population included only 4,250,000 men (counting as a "man" a male aged eighteen years and upwards) devoted directly to mining or manufacturing.

We must not readily conclude, however, that we have even as many as 4,250,000 men engaged in useful industrial production.

For one thing, the Census of Production was taken in an exceedingly good year of trade, when employment was good. If it had been taken in the following year, the number of producers would have been shown as about 4 per cent. less than the above figure. We have also to take account of short time, and of the operation of industrial disease and 


\section{WASTE OF PRODUCERS' WORK 31}

accident, which cuts deeply into the available working time of industrial workers.

But these considerations, important as they are, pale before the waste of work which is involved in industrial processes which are but the servants of unnecessary competition.

Analysis of the work of the few millions of industrial producers shows us that no small part of them are engaged, not in the manufacture of things of personal utility, but in the manufacture of articles or commodities which merely serve the purposes of competitive selling.

Take the printing trade, for example. An unmeasurable, but certainly large proportion of the men, women, boys, and girls who rank in the Census of Production as working in the printing trades, are engaged in printing, not books, or newspapers, or magazines, but advertising matter, competitive price lists, wrappers, trade labels, bill-heads, account books, posters, etc., which are merely called into existence in the struggle of various competitive sellers to reach the consumer. The consumer has to pay the bill for all this printing in the price of the competitive articles which he buys, but what does he gain by the mass of matter which is incessantly thrust upon him? He is bewildered by the appeals 
which are made to him, which are nearly always misleading in some degree, and which in many cases are deliberately intended to deceive. The newspaper reader pays for his newspaper, he fondly believes, only one halfpenny. As a matter of fact, he pays for his newspaper in two ways: there is the direct payment of a half-penny to the newsagent, and there is the indirect payment which he contributes in the prices of things which he buys from tradesmen-prices which are calculated to cover the cost of the advertisements which are daily thrust before his eyes by the newspaper proprietors. One feels sorry for the uninstructed man who, desiring to buy, say, a pianoforte, consults advertisements as the best means of discovering where to buy.

And not printing alone, but many other trades give a considerable part of their output to the uses of advertisement. Iron, copper, zinc, enamel, colour, ink, paper, string, gum, wood-the list of articles which are built up into advertisements to deface towns, despoil scenery, and confuse the traveller, is a lengthy one. The workers upon these things are amongst our few "producers," but their production is in vain.

I think as I write of a lying cardboard bootbox which I saw not long ago in a boot factory. 


\section{WASTE OF PRODUCERS' WORK 33}

It was supplied to the boot manufacturer by a mere middleman, who sells boots for about one-third more than he gives for them. It was a box brightly printed with audacious lies. It bore a picture of a factory which did not exist. It stated that the middlemen were manufacturers, when they were not. It bore words to the effect that the contents of the box went straight from the factory to the warehouse, which was untrue. The printer who set up these abominable falsehoods, and the block-maker who supplied the block of the imaginary factory, and the mill which produced the paper bearing the falsehoods, figure in a Board of Trade Census of Production as "producers," and they are typical of hundreds of thousands who are condemned by commercialism to utter falsehoods built up into all sorts of good, bad, and indifferent materials.

In recent years the absurdity of competition by expensive advertisements, which is sufficiently obvious in regard to what are commonly called manufactures, has been imported even into the domain of food supply. Enormous sums are spent by competitive firms to persuade the public that there are a number of different individual teas, butters, or bacons. Tea bought in the ordinary process in the 
London market is put up into special packets and labelled with fancy names and advertised in terms which suggest that it possesses individual quality like a Beethoven symphony. The consumer does not dream that, in 1913, $366,000,000 \mathrm{lb}$. of tea were imported for the small sum of $£ 13,800,000$, or only $9 d$. per pound, and that when he buys tea he pays a tax of $5 d$. to the Government and a tax of from $4 d$. to $1 s$. and upwards per $1 \mathrm{~b}$. to the middlemen who stand between tea at the port and tea on the breakfast-table. To furnish forth the newspaper advertisements, the posters, the lead wrappers, the paper wrappers, the boxes, and the other paraphernalia connected with the tea selling, means a good deal of "manufacturing," but it is manufacturing which from the point of view of economic production is for the most part a good deal worse than useless.

And if the manufacturing of competitive materials is bad, the manufacturing of rubbish in nearly every department of industry is worse. I repeat here what I have said before, that rubbish-making is our largest industry. It is one of the saddest things in our industrial system to see an ingenious machine, worked by an intelligent man, and driven by an engine which is a triumph of human skill, exercised 


\section{WASTE OF PRODUCERS' WORK 35}

upon shoddy material. The average workman is so used to working upon rubbish that he fails to perceive the irony of it. The bricklayer takes the bricks and mortar as they come along; it is all the same to him whether the bricks be soft or hard, or whether the mortar be good cement or pure mud. The carpenter uses the timber supplied to him by the jerrybuilder, however green, however shaky. The weaver will as readily weave you a shoddy weft on a cotton warp as produce a piece of good, honest, woollen cloth. If our workmen began questioning their materials, I really shudder to think what would happen to their next wages bill, or to what sort of dimensions our industrial production would be reduced. We are surrounded and built in by rubbish. All but a tiny proportion of the houses of the country are furnished with rubbish, and curtained with rubbish, and fastened up with rubbish. The greater part of household coal, which costs its getters so much in life and its purchasers so much in money, is wasted in rubbish grates and rubbish ranges. It is impossible to exaggerate in this connection; the reality is an exaggeration beyond all imagining.

I cannot pretend to express these things of which I have written in statistical terms. I 


\section{THE FUTURE OF WORK}

cannot pretend to decide how many of the 4,250,000 producing men make honest stuff, and how many on the other hand are amongst the rubbish producers. It is only too clear, however, that the rubbish producers are an exceedingly large part of the whole, and that the number of people in the country who make articles worth buying is ridiculously small.

§ 3. Science has Solved the Problem of Poverty

No one who is acquainted with modern machine production can fail to have been struck with the extreme facility with which we can now fashion material commodities. The scientist and the engineer have put plenty at our disposal, if we care to have it. It is not the fault of the inventor or the discoverer that about 4,000,000 men are irregularly employed upon their wonderful machines and processes. That is obviously true, for a large proportion of the originators of modern, industrial processes are dead, and their inheritance is the common property of mankind. 


\section{THE PROBLEM OF POVERTY}

Even as to the living inventor, we are careful to put a very short limit to his powers of monopoly. The inventor of the incandescent gas-mantle is happily still alive, but any man can now employ cheap labour to turn out more or less imperfect examples of his great invention without paying him a cent. There is no secret about modern machine industry. The great body of invention is at our disposal with which to produce plentifulness, and every year the patents of living inventors are expiring.

To visit a modern cloth factory or cycle factory or boot factory or furniture factory, is to witness operations which win from a wonderful complication of devices, and a division of labour between machines made for sectional purposes, an extreme simplicity and rapidity of output. Each part of a boot or a cycle, however small and seemingly insignificant, is turned out by a specialised machine at very small cost. The accurately and beautifully made parts are put together, and the total labour exerted to make one boot or onc cycle is marvellously small. Looking at boot machines, we understand that a very limited number of them, worked by a small fraction of the working population, could easily make more boots in a year than 
our entire population could wear out in several years. Looking at a cycle factory, we understand that it would be the simplest possible thing for a very limited number of people to turn out more cycles than there are people in the country to ride them.

It is not manufacturing which is the trouble to the manufacturer. It is not the work of his factory which worries a manufacturer. The manufacturer's trouble is this, that it is so easy to make things, and so difficult to sell things. It is to selling and not to making that the manufacturer has chiefly to address his mind. From the point of view of economic production, the man who makes boots is a valuable worker, while the man who takes orders for boots, and perhaps by his skill in representation takes an order away from a man who sells better boots, counts for nothing, or worse than nothing, as an economic agent. To the manufacturer, however, the boot-worker is a commonplace object who can easily be replaced, while the successful salesman is all in all. It is an inversion of proper economic conceptions which goes to the very root of the problem of poverty.

The efficient machinery which has been contrived to meet the needs of large scale production of every sort and kind is, as we 


\section{THE PROBLEM OF POVERTY}

have seen, worked by a small proportion of our population. Yet even when thus indifferently and partially worked the machines have but to keep going for a brief period and demand is overtaken. Almost as soon as the wheels begin to run freely, the brake must perforce be put to them, for lack of buyers to command the products which can so easily be made. The machines are run, not with the object of producing goods in plenty, but with the object of reducing costs in connection with a known or an estimated demand. In effect, every machine is run to make one thing and one thing only, and that is individual profit. That profit can only be secured out of the trade which offers, and the trade which offers arises from the limited consumption of a community the mass of whom are wagelabourers paid little more than the bare cost of renting a poor home and buying fuel and food for its inmates. To run the machines freely under such conditions is to attempt the impossible. Each manufacturer, in effect, denies customers to every other manufacturer. Each is successful in putting a brake upon the machinery of every other. The hat-worker cannot afford to buy the boots he requires, which can so easily be made by the bootworker. The boot-worker cannot afford to 
buy the hats he requires, which can so easily be made by the hat-worker. Neither of them can command the cycles so easily made at Coventry, and at Coventry every factory pours out men and women poorly shod and with indifferent headgear.

As for the product which is actually turned out, and supplemented as we have seen by exchanges with foreign parts, it is scrambled for by a host of uneconomic agents who attenuate the poor stream of commodities as it flows through the country.

The case of tea to which I have referred in these pages is typical rather than exceptional. To take retailing alone, the average shopkeeper cannot live on a gross profit less than from 30 to 50 per cent. His retail profit may be insignificant, and often is so. The failures amongst shopkeepers are appalling in their number. But whether they succeed or fail, upon every article they sell they must load on a big gross profit. When, therefore, the wageearner takes his poor wage to market, he has first of all to provide a living for middlemen, whose livings may be as hard to get as his own, while all suffer from the waste of their labour.

There is one certain way of getting very little out of the scramble, and that is to be 
one of the producers. So long as a man is content to remain a useful economic producer, he cannot become even moderately comfortable. If he is worldly wise, he will reason to himself: "There is only one way in which $\mathbf{I}$ can get a chance to make an ample subsistence, and that is by ceasing to make goods, and by entering upon one of the paths by which I can make not goods, but profits." There is no "getting on" possible for the man who continues honestly to make hats, or furniture, or boots, or carpets, or upholstery, as a unit in large-scale economic production. Every industrial producer is condemned to a blind alley and a meagre wage irregularly earned. Can we wonder, then, if an increasingly large proportion of the population has realised this, and has made what is under the circumstances the wise decision to desert production for one of the paths of profit? When there is neither comfort nor honour to be got out of honest work, need we wonder if so many of us prefer to live without working? The -latter course is at least not less likely to fail than the former and offers so many sublime opportunitics!

So it is that the inventors, the scientists, and the engineers have completely failed to make tolerable the lot of the common man. It was in 1828 that George Stephenson ran "The 
Rocket"; to-day, nearly ninety years after, the mass of the British people are unable to travel any considerable distance in their own country by railway, for they cannot afford the fares. The steamship is nearly as old as the railway locomotive; yet to-day the masses are only acquainted with steamships when they are driven into emigration. We possess in electric traction the means of spreading our town populations over considerable and healthy areas; the people remain huddled in their grimy towns, a prey to disease. We are one of the few great coal nations; yet few of our people can afford to warm their houses properly. Vain have been the strivings of the most gifted of men. The machines they have constructed have but created a new race of machine slaves, and made it possible for an increasing proportion of civilised men to live by useless work, while liberating entirely from work, useful or useless, a limited leisure class which alone enjoys the fruits of the earth as multiplied and harvested by machinery.

Is it necessary for so much work to produce so much pain? After taking so much trouble to facilitate production, does it pass the wit of man to organise our labour to better advantage than is shown in the wretched material increment we have examined, made to be 


\section{THE PROBLEM OF POVERTY}

enjoyed chiefly by those who do not produce it? Is it really more difficult to persuade a people to use machinery properly than it is to invent the machinery itself ? Must it be said of civilised man that he can analyse the light of Sirius, but cannot shelter all his children ?-that he can achieve scicntific miracles, but is baffled by the commonplace?

\section{§4. The State Organised for Work}

The answer to the questions just propounded is that, while scientific accomplishment has in the last few gencrations been regarded as a proper study of mankind, we have not yet deemed it our duty to provide our people with comfort. As long as science was a forbidden domain, science made little progress. As long as men regard such a thing as an ample supply of good clothing as a matter to bc resigned to haphazard effort, conducted by unorganised and incompletely informed individuals, working in opposition to each other for privatc gain, the masses of people will remain ill-clad. That is as true as what Machiavelli long ago wrote as to the impos- 


\section{THE FUTURE OF WORK}

sibility of conducting successful national military operations by purchasing the services of condottieri. No nation will ever be well housed, well clothed, well fed, and well cultured while it is content to cherish industrial condottieri. Not until the soldier of fortune is as much an anachronism in the industrial as in the military world, will there be an output of commodities of such dimensions as to abolish material poverty, and of such rapidity and ease of production as to abolish the distinction between classes by creating a universal leisure won through the ordered, scientific use of economic appliances.

Is this to envisage as a worthy ideal a Great State running as a Great Machine, the welloiled wheels of which are the lives and labours of drilled and enslaved citizens? Does the reign of Order necessarily mean the loss of liberty, of individuality, of personal choice, of captaincy of one's own soul?

The answer to these questions will appear to those who consider carefully the considerations which have been advanced in these pages. Production has become so simple that, if a people will but consent to organise for the production necessary to yield a high minimum standard of subsistence for the entire community, the necessary labour will occupy so 


\section{STATE ORGANISED FOR WORK 45}

small a proportion of the day of the community's adults of working age, as to produce for every one such a measure of liberty as can now be enjoyed in dishonourable ease by but a few. I have led up to this proposition by showing (1) that present production is the work of a few, (2) that the work of even that few is largely wasted, and (3) that the means of production are now so efficient as to make it possible to produce easily much more than we can possibly consume.

In our community of some $46,000,000$ people (1914) there are about $28,000,000$ over eighteen years of age. It is clear, then, that if training merged into economic work at eighteen, the number of workers would be so great as to make it possible to organise, in a very brief working day for all, the efficient production and distribution of the materials necessary for a high minimum standard of living. If a few millions of men, aided by a million or two of women, boys, and girls, can create and sustain the material fabric we now know of, in spite of the interruptions of unemployment, preventable sickness, and avoidable accident, what could not be done by the entire nation, engaged in economic labour, and working with the aid of the most efficient appliances in each department of production? One cannot pre- 
tend to make estimates in such a matter, but I submit with confidence that an ample output in all the departments of civic, home, road and transport maintenance, construction and repair, of lighting and heating, of cloths and apparel, of foods and beverages, of indoor and outdoor furnishings, of afforestation and land development, of certain public amusements and exhibitions, could be secured in a very short working day, leaving the greater part of the life of an adult absolutely free, within the limits of common rule, for the pursuit of individual occupations, researches, travels, and amusements, the leisure dignified and justified by the ordered maximum of labour, and the necessary labours of the Commonwealth deprived of monotony and hardship by the gain of honourable leisure.

But let us endeavour to get definite conceptions of the possibilities of necessary order and admired disorder, of organised work and unorganised work, of law and of liberty, of professionalism and of amateurism, in this Great State that we dare to dream of.

At the age of, say, eighteen years, the youth will pass into apprenticeship to some definite branch of the organised work of the Great State. It is not my province here to deal with the education which will fit him for serious, 


\section{STATE ORGANISED FOR WORK 47}

professional service. Basing myself upon the known fact that an average child, given proper training, is the inheritor of the normal capacity of his race, and can be developed into a man useful to himself and to his fellows, I postulate an education worthy the name. I see the average boy of eighteen, not only healthy, but understanding why he is healthy, and what branches of the professional work of the State are necessary for the maintenance of that public health in which he shares. I see him thus respecting his own body and the bodies of others. His eye is clear, and his touch is deft and firm. He moves with grace and precision, and his hands are skilful. In the region of acquired knowledge, as distinguished from the education of his inherited powers, he is acquainted with the elements of science. He knows the quality of the Nature from which he has emerged, so far as it has been revealed by the sciences of geology, biology, chemistry, and physics. He has taken up the magnificent inheritance of knowledge which as yet not one in ten thousand of our people enjoys. By virtue of this inheritance, he understands the physical world in which he has his being. For him there are sermons in stones, and good and evil in everything. He rejoices in his knowledge as he rejoices in his 
strength. His acquaintance with first principles enables him to scan a machine with an eye of intelligence. There is no common object of that conquest of Nature which we call Civilisation which has mystery for him. He therefore understands why work is necessary, and why Nature has not merely to be conquered in one final decisive battle, but in the every-day of a never-ending struggle. What imagination he has and what native powers he possesses, are widened and deepened and multiplied by the knowledge which makes him one of the chain of Nature's conquerors. Withal, he has read in the history of the races of man, and in the literature and philosophy which has been the expression of the best of men, and the structure of society, and the manner of the governance of society, are known to him in their forms and in their conceptions.

Thus I sec the normal educated youth of the Great State, and I cannot see a Great State based on anything less. Without general culture of a kind which is not now possessed even by our ruling classes, I can see nothing more than the possibility of a Socialist bureaucracy, a Servile State, a later Peruvian Socialism, with its general order of docile units and its upper order of a ruling and informed caste. 


\section{STATE ORGANISED FOR WORK 49}

I do not deny that a socialistic bureaucratic State might be infinitely superior to our existing admixture of bureaucracy, feudalism, and private individual governance for purposes of individual gain, but let us build as greatly as scientific attainment gives us leave to envisage the future, trusting that we may be really building even greater still.

I picture the educated youth of eighteen, choosing his professional lot.

It is necessary here to interpolate the supposition that the Great State will express the results of the professional work done within its borders-the results, that is, of that maximum of individual labour which its citizens will owe it-in money, and that the income, or share of the results of professional work, which all will enjoy, will be spent in the form of money by citizens free to command with that money whatsoever the Great State produces.

A call for commodities being a call for labour, the Great State will be able to measure unerringly for what kind of labour the people call. It will also know what quantity of human work, aided by the most economic appliances known, is needed in cach department of production called upon by the people's aggregate expenditure. 'Thus, in any par- 
ticular year, as the youth of the nation reaches the age of entry into professional labour, a certain number of apprenticeships or openings will be available for the new workers of the year. It is not difficult to conceive arrangements, combining elements of choice with clements of examination as to qualifications, which shall draft the youth of the year into the professional work of the nation. The average element of choice will be a thousandfold wider than now, and liberty in this respect thus a thousandfold wider. For all but an insignificant fraction of the youth of our State that is, there is in practice no choice, and, even where choice exists, it is but as a choice of evils. Narrow indeed is the gate, and strait exceedingly is the way, for the son of a Glamorganshire miner, or of a London bricklayer, or of a Leicester boot-hand, who reaches the thirteen ycars of age at which he is ejected from the sham schools wherein we mock the name of Edueation.

And this enlarged liberty in choosing the way of professional life, it must be remembered, although necessarily finding bounds to its freedom in the necessities of society and the limitations of the individual, is, it is necessary to insist, but the committal of the individual to that part of his life which is to be professional. 


\section{STATE ORGANISED FOR WORK 51}

True it is that this side of life must have its limitations to freedom, its elements of compulsion, its inexorable call to duty, and its door shut against escape from honourable toil. But this side of man's life will not necessarily be the larger side. Every professional of the Great State will be also an amateur of what arts, what occupations, he chooses.

Again let us remember that in our $46,000,000$ of people, there are $28,000,000$ of over eighteen years of age. What might not 26,000,000 persons-to deduct the $2,000,000$ over sixtyfive years of age-do even to-day, with science and invention no more developed than it is, if their labour was organised without competitive waste, and excrted not for individual profit, but in the production and economic distribution of useful products and services?

The conception of the Great State is that the whole of its adult population will be organised to produce a minimum standard of life, expressed by the output and distribution of the material products and services necessary to its maintenance. This work is what I term the professional life of the individual. It is the performance of his social duty. It is a thing of written law and compulsion. And because it is universal and compulsory, and because the wastc of effort will be reduced to 
an insignificance, the professional or compulsory work of the individual will occupy but a few hours of his day. Even now, were the thing possible, as most unhappily it is not possible, the adult units of our people, officered by the small proportion of informed people we possess, could probably do all that is now usefully done in not more than a five-hours' day. With a universal scientific education, less than a five-hour's' day of labour for adults will produce a bulk of commodities and services many times greater than now obtains.

The economic contraction of professional life means the widening of freedom. Beyond his professional work, the citizen will owe no duty to the State, and he will be free to do anything which is not to the injury of his fellows. For the greater part of his working hours, that is, he may be poet or painter, writer or philosopher, singer or musician, actor or dramatist, carver or sculptor, even sportsman or idler.

I cannot conceive a professional actor in the Great State; I can only see amateur actors, robbed of those unfortunate attributes that come with eternal pose by healthy work done in a healthy world. I cannot imagine a poet selling his epics in the Great State; I can only see amateur poets, whom the Muses shall visit 


\section{STATE ORGANISED FOR WORK 53}

the more frequently because they are engaged in the useful work of the world. I cannot conceive in the Great State would-be professional painters ruined by drink and the devil while waiting for rich parvenus to appreciate their Venuses ; I can only see healthy creatures painting because they needs must, and painting what they want to paint. As for the great army of writers, journalists, ministers of all denominations, dancers, philosophers, lecturers, and others, who now escape from legitimate labour, and from their honest share of what needs to be done that we all may live, sometimes escaping because they are clever, sometimes because they are morely artful, and sometimes, Heaven knows how, when they are neither clever nor artful, there will be no room for them as professionals in the Great State. They may write for such as will read, they may mime for such as will look, they may lecture for such as will hear, they may preach to such congregations as their gifts may command, but they will do so as amateurs, and their labour of love will find its meed in that self-respect and public honour which are amongst the chief rewards possible for man.

Thus I picture an amateur life of individual work and recreation embroidered upon the 
main social fabric formed by exertion in professional work.

The amateur side of life in the Great State will need its materials. Those materials will be partly purchased with money out of State production through the individual's ordinary income which expresses his minimum wage, and partly supplied by amateur effort and exchanges between amateurs as amateurs. This side of the subject presents no difficulty. We can see the amateur carver working upon wood the produce of State professional production. 'We can see the amateur company of actors hiring one of the Great State's theatres and performing with dresses and effects partly purchased out of income from State stores, and partly furnished by amateur effort, or by amateur claboration or decoration of State materials. The poet's pen and ink, the artist's tools and colours, the amateur publisher's paper and machinery, will all alike be commanded out of State production by professional income and elaborated or worked with in amateurs' time.

The newspaper of the Great State will be a plain record of home and foreign happenings. It will record home and foreign affairs, the progress of industries, the growth or decline of peoples, the judgments in cases of dispute 


\section{STATE ORGANISED FOR WORK 55}

or arbitration, the births and marriages and deaths, the departures of travellers, the arrival of visitors, the accidents or misfortunes in its homes and factories. It will not record opinions, or be concerned with policies. Organs of opinion will be purely amateur in ownership and direction. An organ of opinion will not be published for gain, but to express the thoughts and desires of those who publish it. Obviously, they will not desire to publish unless they think earnestly and strongly, and for a man or society of men who think thus it will be easy to publish. The professional income of twenty men or even ten will command paper and machinery, and by their own amateur labour they will speak their mind. If such speaking gains hearers, it will gain supporters, and a large circulation will be possible-not a circulation contracted for with advertisers, or a circulation which needs must be to give so many people a living whether they want to write or not, or whether they have anything to say or not. Thus the organs of opinion of the Great State will live honestly or not at all, and even the least of poetasters will find it less difficult than now to produce his little volume of verses for the cdification of his friends.

I see that in some ways the professional and 
amateur worker of the Great State will join hands. "It is my pleasure," said the German municipal architect to me, as he waved his hand towards the municipal dwellings. I see amateur painters competing for the pleasure of decorating with frescoes the panels of a new Town Hall-amateur painters who professionally may be carpenters, or clerks, or masons, or engineers, and who, assured of an ample income by their professional labour, will aim at the honour of making their own monument in amateur work done for the public good. I see no reason to suppose that the professional workers of the Great State will not be as ready to sacrifice their lives, if need be, as some amongst our leisure classes are ready to-day. Even as I write $I$ think of the common men who offered their lives in connection with experiments in tropical disease at Panama-the experiments of State "officials." The amateurs of the Great State will be the labour class, and the professionals of the Great State will be the leisure class, and all these will be one. I have faith that there is that in man which will build greatly on this conception, and I see no reason to set limits to the strivings of man under such conditions.

It is possible that for long; if not for ever, 


\section{STATE ORGANISED FOR WORK 57}

there will remain many tasks necessary to civilisation which will call for unusual physical exertion, or the suffering of unpleasant physical conditions, or even the risk of life. For example, we do not know for how long the world will be dependent upon coal for its supplies of energy. Let us suppose that the Great State will be so dependent. Does the supply of labour for such work present difficulties? The answer is that labour of this kind will be done in the Great State by sharing it amongst the able-bodied. The Great State will regard it as a thing impossible to condemn a man to be a coal-miner for life. For my own part, I always regard the devotion of a definite section of our people to mining as a sentence of penal servitude upon them. It goes without saying that the Great State, if it uses coal, will conserve it, so that coal-mining will be reduced to a minimum. That minimum will be performed, not by a definite few for life, but by all able-bodied men for a period. Mining is much more dangerous than soldiering, and calls for the application of the principle of conscription. The mining conscript will go to his term of service as a matter of duty and with pride. In after time he will look back upon his mining years, and because of them he will the better understand the society in 
which he lives and the relation of labour to life.

Such a plan will avoid the cruelty and the waste of setting a definite million-for that is what we now do in effect-to do a particularly hard and dangerous form of work. We cannot afford to bury in a coal-mine, without chance of redemption, lives of we know not what possibilities. We cannot give every man adequate opportunity unless we give every man more than the prospect of unending toil in a single groove, and unless we provide every man with leisurc.

Individual saving will be both unnecessary and unknown in the Great State, and the form of saving known as insurance will be read of in history with considerable amusement. What capital saving is necessary will, of course, be done out of the product of the State's professional work, and the only " wastage" in connection with this capital saving will be the devotion of a certain amount of labour to experiment in every branch of production, although amateur experiment will be plentiful, because of the fullness of opportunity for the prosecution of individual tastes and inclinations in the arts and sciences. The devotion of the professional work of the State to the best materials and in the best way will, of 


\section{STATE ORGANISED FOR WORK 59}

course, reduce the need for labour upon eapital work, since replacements and repairs will be less needed on account of wear and tear. No vested interests will impede the substitution of one process for another, or of a better for a worse invention.

As need hardly be added, there will be a tremendous increase of really personal property in the Great State, and nothing will prevent the bequeathing or the inheritance of such personal property. Obviously, however, a man will not burden himself with more personal property than he can eare for, and he will be quite unable to command menial servants to take charge of an excess. Thus personal property will naturally limit itself to those really personal implements, books, papers, musical instruments, etc., which pertain to the needs, habits, and tastes of the individual. The means of producing professional income will belong to the Great State, and no private individual will therefore be able to control the work of his fellows. He will be able to get amateur service from a friend; he will have no economic lien upon any man. The citizens of the Great State will be amused when they recall days when men possessed bits of paper representing a fraction of a municipal sewer, or of a railway line, or of a colliery 
plant, or of a calico shed, or even of a druggist's shop, and when, by virtue of such ownership, a man could live without continuing to labour. No, interest will not exist in the Great State, but every man will realise before he passes into the work of the world that he is one of the nation's common inheritors, and that it will be his personal interest, as it is not now, to swell the value of the common undertaking - to increase what will be really and not nominally a National Dividend.

The mutation of industrial processes in the Great State will be an exceedingly simple matter. To-day, the man who invented a method of building houses with one-half the present amount of labour would condemn to ruin, and in many cases to utter destitution and degradation, hundreds of thousands of families in every industrial nation, and the economic effects would not pass until tens of thousands of heads had been plunged under water. Indeed, under present conditions, it is a mercy when dullness of perception, or the usual lack of enterprise of capitalists, keeps a new process hanging fire for some years.

In the Great State the invention of a process to halve the labour in a great branch of national industry will mean simply the reduction of the working day of the citizen as pro- 


\section{STATE ORGANISED FOR WORK 61}

fessional without the reduction of his income, and the pro tanto increase of his leisure as amateur. Thus, every new invention will be hailed joyfully as meaning either the decrease of work with the same income, or a larger income for the same amount of work. Let that be understood in a community of educated people, and the spur to invention will take us to means of accomplishment as yet undreamed of.

For the woman the Great State spells Economic Independence, and the end of marriage as a profession. The marriages of the Great State will be between economic equals, and only maternity will release a woman from her professional duty. Motherhood, of course, will be the pcculiar care of the Great State, and for a certain number of years the mother will draw her professional income as mother, in addition to an endowment for each child, and the child will be in no sense dependent upon the work of its father. I see the budding girl's education in the Great State regardful of her supreme function, and the training and nurture of the ehild regarded as the professional duty of a woman both before and for some time after the beginning of the age when it will begin systematic training in the school. Thus, some ten or 
fifteen years of the life of most adult women will be divorced from the professional material work of the State, but before the beginning, and after the end, of that period, the adult woman will work at the profession into which she has been inducted in the manner we have already indicated.

It is not necessary, at the end of the first decade of the twentieth century, to say very much by way of argument that it is possible for the major industries of a nation to be unified and placed under State controls. Some forty years ago John Stuart Mill wrote that "The very idea of conducting the whole industry of a country by direction from a single centre is so obviously chimerical that nobody ventures to propose any mode in which it should be done." Since those words were written, it has been proved abundantly that large-scale operations conducted under the general direction of a central control are not merely possible, but possess such advantages in practice that business men have been led to consolidate trade after trade in all the great industrial nations, and especially in the country, America, which by reason of the magnitude of her population and natural resources, presents the largest factors to deal with. Thus the United States Steel Corporation, which is a private 


\section{STATE ORGANISED FOR WORK 63}

"State within the State," is a far larger industrial undertaking than would be formed if all the iron and steel works, including the iron-mines, of the United Kingdom were unified under a single public direetion. We have recently had the chairman of this great organisation-Judge Gary-seriously proposing to the United States government that it should take control not only of his own great business, but of all the American industrial combinations, familiarly known as "Trusts," which are engaged in inter-State trade. He suggested that an American State Department should be set up to take eontrol of these largescale operations, and that the Uepartment should be charged with the determination of production and prices.

We need to see a little more clearly that this is quite a small country, and that its industrial affairs are very small alfairs-things of easy comprehension and susceptible of effective State control by even dull fellows. When Judge Gary talks of the soeialisation of the American Iron and Steel Trust, then indeed we have to envisage a conception of a considerable order of magnitude. 'The 'Irust operates in far-flung territories, beside which the whole of the United Kingdom, to say nothing of the mere area of our iron industry, is a little spot 
on the map. 'The Trust has an output greater than that of all the British iron and steel firms, large and small, lumped together. The Trust produces from its own mines nearly twice as much iron ore as the whole of Britain produces, and it makes far more than twice as much steel as all Britain produces. The practical possibilities of large-scale control have, therefore, been conclusively demonstrated. 'To a chairman of the American Steel Trust, the central control of an enormous business presents itself as an accomplished fact. Let it be clearly realised that therc is no British industry which, if converted into a national industry, would form as great a unit of industry, or as difficult and complex a problem for central governing powers, as already exists in the world in active and successful operation at this moment.

The success of the concentration of capital in improving industrial output in America has naturally influenced the views of American economists. We find Professor Van Hise of Wisconsin University promulgating the doctrine that competition is injurious to the community, because it wastes energy and capital, and boldly asserting that combination and co-operation are necessary to the fullest development of economic powers. 


\section{STATE ORGANISED FOR WORK 65}

Fortunately for mankind, there are some industries which illustrate this point by calling for the employment of rails, wires, pipes, or conduits. These may be termed object lessons in the folly of competition and the virtue of co-operation. If a town has to be lit by gas, it is obvious that a single gas generating plant and one properly co-ordinated set of gaspipes is sufficient. Such a system is a working model of co-operative industry, and consequently, even if a gas company makes exorbitant profits, it gives consumers better value in gas than they can get in cabbages or milk or pen-knives. It is amusing and instructive to observe that those economists who have clung to the worship of competition have sought to put the what I may call "pipe and line" trades into a class by themselves by terming them " natural monopolies." I am tempted to remark " natural fiddlesticks." If it is good and wise and for the public welfare for the milk supply of a town to be in the hands of, say, ten competitive milk merchants, sending their chariots and their men and their boys into every street of the town to find customers, and to distribute milk and mierobes, it is equally good and wise and for the public welfare for ten separate gas merchants to set up ten generating plants, to lay ten sets of 
pipes in every thoroughfare, and to hunt for customers in every thoroughfare. Indeed, given ten such plants, the gas would be supplied more economically than the milk, because the upkeep of ten competitive gaspipes in a street is not so costly as the upkeep of ten milk carts and their attendants daily perambulating in the same street. If, then, there is virtue in competition, the economists who defend it should have the courage of their opinions and advise us to multiply indefinitely our gas mains and water mains and sewers and electric cables.

I am not arguing a reductio ad absurdum. The economist did give such advice, and it was seriously acted upon by Parliament for years long enough to give us the ridiculous and wasteful network of railways in the wrong place which we call a railway "system." Parliament was all for railway competition in the unhappy days when speculators came to it for railway powers. To this hour we can see trains running almost side by side in what is for practical purposes the same street, and standing on a junction platform with the dearly purchased ticket of one railway in our hands, we are forbidden to enter another company's train going to our destination. Yes, the old "economists," and the legislators 


\section{STATE ORGANISED FOR WORK 67}

who believed in them, did their work only too well.

But, be it observed, although our railway rates and fares are high because the folly of competition gave us a railway system burdened with a gigantic fictitious capital upon which a profit of nearly $£ 50,000,000$ a year pays but a poor rate of interest, British railways are far more economical than British industries in general. The penny a mile thrust upon the railway companies (who declared it would ruin them) by Parliament is poor value, but it is splendid value as compared with a pennyworth of coal or a pennyworth of milk. For, although Parliament sanctioned and encouraged competition in railway building, the commonsense of cooperation is so clearly illustrated when rails or pipes have to be used in an industry, that not nearly as much competition went to the making of our railways as went to the making of other trades. Those who argue that they are not Socialists, but that they believe in railway nationalisation, show that they do not know what very good Socialists they are; for, much as our railways sin, they give us better value than our trades in general, and as a whole, inefficient as they are, they are far more efficient than our trades in general. The 
man who argues for railway nationalisation is beginning at the thick and not at the thin end of the wedge.

The truth is that the economic consolidation of all the factors of an industry in the State eliminates difficulties, instead of creating them as was supposed by the older economists. Thus if we take the very familiar case of the Post Office, the ease with which its operations are conducted is often attributed to the inherent simplicity of the trade. As a matter of fact, the business of collecting, transmitting, and delivering letters is one which, if it were not organised as a single unit, would be one of infinite difficulty and complexity. Imagine it organised under the direction of some hundreds of partly competitive, partly monolistic, local or district letter delivery firms, each necessarily having accounts with each other, and the jurisdiction of each running no further than a certain local limit, more or less wide, and sometimes overlapping with the area of operations of a competitor. Imagine then the postal communications of an unfortunate person collected by some one firm, transmitted through several others, and finally delivered (or not delivered) by a company in the district of the addressee. Imagine the charges piled up to pay the host of unnecessary 


\section{STATE ORGANISED FOR WORK 69}

between-agents, the vexatious delays that would arise, the consequent restriction of postal facilities and slow growth of communication. With such an economic absurdity in being, we can imagine a second John Stuart Mill gravely pointing out in an economic treatise that such a complicated, such an inherently difficult, such a vexatious trade could never be successfully carried on by a State department. But this picture of a disintegrated postal service does not tell onefiftieth part of the everyday absurdities of our organisation for the distribution of groceries, or meat, or dairy produce, or vegetables. In these, we tolerate the waste of hundreds of millions a year in setting millions of men and women to waste their time as unnecessary, and often unhappy and overworked, betweenagents, who earn mean and paltry livings while simply serving to attenuate the streams of commodities which under happier conditions they might swell. In the distribution of coal, for example, we have in practice a case much more wasteful than we have imagined if private were substituted for public lettercarrying. It is a case not merely of separatc controls in each area, but of insane competition in each area between middlemen whose expenses are necessarily great-cxpenses which, 
from invoice forms to advertisements, have each and all to be paid for by the consumer in the final price of coal. So it falls out that often the consumer of coal pays a high price for the fuel even while the hewer of coal is obtaining a mere trifle for getting it. The mining of coal by the State and its distribution through local authorities as agents would, on the other hand, with an organisation much simpler than that of the Post Office, put coal at a nation's disposal cheaply and conveniently, and with complete guarantee as to grade and suitability for specific use. Or it could work out a great scheme of universal electrification and make coal distribution entirely unnecessary.

In this connection, the American Bureau of Labour Statistics has performed a great service, not only for America, but for the world, in investigating waste and the mysteries of price in respect of wheat and flour in the United States. Its official investigator, Mr. J. Chester Bowen, has published a most interesting monograph showing what the farmer gets for his wheat and what is paid ultimately for the various products produced from the wheat. He demonstrates how, in a competitive society such as that of the United States, there stands between producer and consumer a host of handling and distributing agencies. All the 


\section{STATE ORGANISED FOR WORK 71}

intervening agents have to bc paid out of the final price which is obtained retail. In other words, the ultimate consumer pays everybody. When the American woman gocs into a shop and buys flour retail, her money pays a long string of agents who between them placed the flour at her disposal. It is extraordinary into how many fractions a coin spent retail comes to be divided as between all the various producers and middlemen concerned. As this American report puts it, "Everybody dealing in wheat and wheat flour is doing so for the profit he expects to make." Observe the hands through which the wheat of the farmer has to pass before it reaches the American retail purchaser of flour :

(1) The grain elevator.

(2) The railway.

(3) The grain jobber, or commission man. (Two or more of these may handle the same lot of wheat.)

(4) The flour miller.

(5) The flour jobber, or wholesale grocer. ('Two or more jobbers may handle the same lot of flour.)

(6) The grocer.

All these agencies have to get their margin of profit or perish. Between the farmer and the retail buyer there stands a great army 
of profit-makers. In each group of betweenagents there is competition, and sometimes severe competition, but the obvious limit of that competition is a margin of profit which enables each individual of the group to live. Margin upon margin thus comes to be added to the original price which the actual producer of the wheat received. Here is the price history of a bushel of Kansas wheat:

\begin{tabular}{|c|c|c|c|c|c|c|c|}
\hline & & & & $\begin{array}{c}\text { A. } \\
\text { Paid to } \\
\text { Farmer. }\end{array}$ & $\begin{array}{c}\text { B. } \\
\text { Retril Price } \\
\text { of Ultimate } \\
\text { Products } \\
\text { (Flour, } \\
\text { Bran, etc.) } \\
\text { of \& Bushel } \\
\text { of Wheat }\end{array}$ & $\begin{array}{c}0 . \\
\text { Margin } \\
\text { between } \\
\text { Farmer and } \\
\text { Retail } \\
\text { Purchaser. }\end{array}$ & Margin. \\
\hline $\begin{array}{l}\text { 1906. March } \\
\text { Oct. }\end{array}$ & $\dot{.}$ & : & 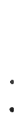 & $\begin{array}{cc}\text { Per Bushel. } \\
s . & d . \\
2 & 8 \\
2 & 4\end{array}$ & $\begin{array}{ll}s, & d \\
4 & 6 \\
4 & 2\end{array}$ & $\mid \begin{array}{cc}\text { Per Bushel. } \\
s . & d . \\
1 & 10 \\
1 & 10\end{array}$ & $\begin{array}{c}\text { Per Cent. } \\
68 \\
78\end{array}$ \\
\hline $\begin{array}{l}\text { 1910. March } \\
\text { Oct. }\end{array}$ & . & • & & $\begin{array}{rr}3 & 11 \\
3 & 6\end{array}$ & $\begin{array}{rr}5 & 11 \\
5 & 7\end{array}$ & $\begin{array}{ll}2 & 0 \\
2 & 1\end{array}$ & $\begin{array}{l}51 \\
59\end{array}$ \\
\hline $\begin{array}{l}\text { 1911. March } \\
\text { Oct. }\end{array}$ & $\dot{.}$ & . & & $\begin{array}{ll}3 & 3 \\
4 & 1\end{array}$ & $\begin{array}{ll}5 & 3 \\
5 & 8\end{array}$ & $\begin{array}{ll}2 & 0 \\
1 & 7\end{array}$ & $\begin{array}{l}61 \\
38\end{array}$ \\
\hline
\end{tabular}

(We may note in passing how this table brings out the great increase in the price of wheat between October, 1906, and October, 1911. It will be seen that in October, 1906, the farmer got $2 s .4 d$. per bushel, whereas in October, 1911, he got $4 s$. 1d., an increase of 1s. 9d., or about 75 per cent.)

Column A of the table shows the price 


\section{STATE ORGANISED FOR WORK 73}

received by the farmer from the elevator. Column B shows the retail or ultimate price of the products derived from a bushel of wheat. Column C, being the difference between Columns $\mathrm{A}$ and $\mathrm{B}$, shows the margin separating the price received by the farmer from the price paid by the consumer. Column $\mathrm{D}$ shows the margin expressed as a percentage.

It will be seen that the margin is a very big one, ranging between $1 s .7 d$. and $2 s$. $1 d$. per bushel of wheat, or, expressed as a percentage, ranging between 38 per cent. and 78 per cent. of the farmer's price. On the whole, it appears that the middleman's margin has tended to fall as the producer's price has advanced, although the figures for 1912, if we had them, would probably show that the 38 per cent. margin of October, 1911, was soon increased.

Amongst the agencies which go to produce the margin, transport and milling are obviously necessary functions, but cven as to the milling or manufacturing of the wheat into flour, it is easy to show what an enormous amount of waste obtains in the United States. There are far more flour mills in America than the country requires to mill its wheat, and a great amount of unnecessary capital is employed. "It is asserted," says the official report, 
"that the mills of the United States could grind all the wheat raised in the United States in 144 days," if worked continuously. "The North-Western Miller" is able to state, as the result of an inquiry, that the mills of Kansas produced only about one-half of their capacity in the period from 1908 to 1911.

But at every point the grievous waste of the competitive system stands revealed. A host of local dealers, millers, and jobbers, many of them quite unnecessary, bid against each other in buying and selling. Flour is made in town $A$, and sent by rail to town $B$, even while flour is being made in town $\mathbf{B}$ to be sent to town A. It is not a little amusing to think of the two unnecessary freight trains passing each other on the railroad, childishly conveying flour in opposite directions and wasting the time of millers, dealers, railwaymen, etc. The report says : "And not only are the products crossing trails in distribution, but travelling salesmen of many mills and flour jobbers are duplicating their labours in the same territory. Beginning with production, there are more seeding and harvesting machines in the hands of farmers than would be needed if there were co-operation in production and each machine kept in operation the entire harvest season. There are more 


\section{STATE ORGANISED FOR WORK 75}

elevators in the wheat area than are needed, each operating most of the time on less than its full capacity. In some sections there is needless duplication of railroad trackage. More grain jobbers and commission men are in the field than can find continuous business."

Thus also it is, mutatis mutandis, with the production of, and trade in other commodities. The consumer goes to a shop and buys carpet at, say, $4 s .11 d$. per yard. 'The manufacturer's price for this carpet-the price that is returned to the Board of Trade in the Census of Production-would be $3 s .6 d$. per yard less $2 \frac{1}{2}$ per cent. discount. That is to say, the gross profit on each yard of earpet is $1 s$. $5 d$., or over 40 per cent. Out of this gross profit he has to pay for rent, rates, labour, printing, railway rate, etc., so that the net profit is much less than 40 per cent. Nevertheless, much of the big gross margin stands for waste.

It will be perceived that the gross profit of over $1 s$. $5 d$. on each yard of carpet is greater than the wages paid for the labour which made the yard of carpet. If, out of each yard of carpet made, the carpet workers could get $1 s .5 d$, they would rejoice exceedingly.

If, therefore, we want to see the true relation between output and wage, we must have regard not only to the manufacturer's 


\section{6}

\section{THE FUTURE OF WORK}

factory price, as returned to the Board of Trade for the purposes of the Census of Production, but to the ultimate price paid by the consumer. If we pay attention to that, we see what an essential part of the wages question is the waste of labour which takes place between the production of goods in the factory and their ultimate distribution. Even the manufacturer's factory price of $3 s .6 d$. for the yard of carpet includes some cost of distribution and other wasteful charges, for he is in competition with other firms, and he has to maintain his separate staff of travellers and clerks, and to pay for advertising, etc., all of which has to come out of the wholesale price which he receives. When the carpet leaves his factory, however, the waste becomes enormous. Sometimes there are wholesale intermediaries who trade on a margin of about 10 per cent., leaving the balance of 30 per cent. or so to the retailer. The extortionate British railway rates of course enter into the margin. Then in each town there are the competitive traders struggling for what custom there is, and each keeping up his expensive establishment, which, if you visit, you may often find containing more shop-assistants than customers.

I am able to state upon unimpeachable 


\section{STATE ORGANISED FOR WORK 77}

authority, the hard test of accomplished fact, what the cost of distribution may be reduced to. A certain boot manufacturer owns his own retail shops and sells boots ranging in price from about $10 s$. to $16 s$. per pair. He pays his shop managers and other retail assistants more than the usual rate. He finds that it costs him no more than $9 d$. a pair to retail his boots, this $9 d$. covering all costs, from rent to shopboy's wages. Yet the retail customer usually pays $3 s$. $6 d$. a pair retail profit on $10 s .6 d$. boots, and $5 s$. on $15 s$. boots.

The host of intermediaries are as to each unit perhaps working hard. Let nothing here said be interpreted as reflecting upon any one of them. They are doing what they needs must do, and that which it is honourable and proper for them to do in the existing circumstances. Nevertheless, for a great part of the host of between-agents, the work done, from a social point of view, represents nothing but sheer waste of labour, and the fact that each of the between-agents has to be remunerated out of the final price obtained for the product, necessarily means that the real producer of the material commodity must go with an inadequate reward. This, of course, is only another way of saying that if one could limit the cost of distribution to 
the small and reasonable margin which is necessary, a great army of workers could be transferred to actual production, so that a much greater amount of real wealth would be produced and there would be a larger National Dividend of material commodities.

And what is true of carpet is true of cabbages. There would be no difficulty about paying agricultural workers a better wage, if out of the prices which retail consumers pay for potatoes, cabbages, or any other form of foodstuff, the actual producer of the foodstuff could get a proper share. Buy a cabbage for threehalfpence, and you pay a price which ought to give a good wage to the man who raised the cabbage. He does not get that wage, because a host of between-agents stand between the soil and the kitchen. Mr. Christopher Turnor is responsible for the following estimates of middlemen's profits on various products of agriculture:

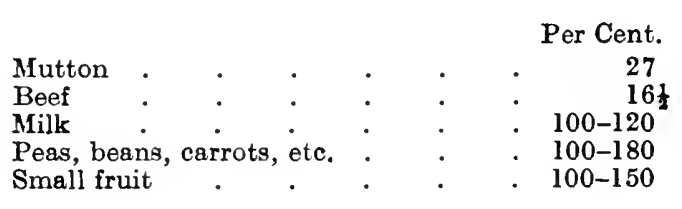

And so it is with each of the industries which contribute to what ought to be the comforts of a modern civilisation, but in practice are 
the comforts of a few bought by the largely wasted labour of the comfortless many. To write a plain and unvarnished account of what happens to the milk produced in the United Kingdom, or to the tea landed in the United Kingdom, or to the wool imported into the United Kingdom, is to describe a series of absurdly complicated and wasteful operations which in great part are as economically useless as to set men to dig and to fill them up again. For example, wool imported into Britain is chiefly used in Yorkshire, but the greater part of it is childishly landed not at Hull or Goole, but in London, where it is played pranks with by hosts of railway companies, carriers, warehousemen, brokers, auctioneers, etc. After having been played with, and pro tanto raised in price, it is gravely conveyed, again by competitive railway companies and carriers, to the worsted and woollen industries in Yorkshire. But this is to imagine no waste prior to the ridiculous landing at a port hundreds of miles from the place where the material is wanted. When we remember that in Australia, or Argentina, similar absurdities occur and similar uneconomic "livelihoods" are made out of the product by the wasted work of thousands, we have a picture of waste from start to finish which gravely 
reflects upon the competence of mankind. There is, of course, no need for such complications. The Great State of Australia could transmit its wool simply and surely to a woolconsuming land like the United Kingdom; here the wool department of the British Great State would obviously see that the wool was landed at the nearest port to its place of use. Not a broker, not an agent, not an auctioneer, would be needed; the number of necessary carriers and distributors would be few through the simplicity of direction; the worsted and woollen industries would get their raw material cheaply and, at last, honestly, and thousands of men would be set free from work upon waste to do the economic work for lack of which we remain poor.

Something may usefully be said with regard to the simplification of exportation and importation. A hint of the possible improvement of facilities which would arise between nations properly organised for work is also to be found in existing postal arrangements. The ease and certainty with which postal communications are exchanged between nations have become a commonplace, but regarded in relation to the great majority of international dealings they are miraculous. The economic reasons for interchanges between geographical 


\section{STATE ORGANISED FOR WORK 81}

areas would remain in a world of federated Great States; all that would be removed would be the main difficulties which now impede exchange. No longer should we witness such sad spectacles as the holding up of raw cotton by one set of agents in America to retard the progress of the very cotton manufacturing industry upon the success of which the real gain of a cotton-planter naturally depends, or of the Brazilian Government arranging for the solemn burning, or holding up, of a fine harvest of coffee even while millions in the world have not coffee enough. Nor is it difficult to realise how in a world organised for economic labour under the captaincy of Great States, all the factors of the great industries throughout the world could be co-ordinated, from the production of the primary materials to the distribution of the finished articles, effecting a proper relation between the producer-consumer and the consumer-producer, making every man a citizen of the world, and giving all the world to each man's use.

Such are the hopes which man can legitimately cherish for the control of the Nature from which he has emerged in this one of the least of Nature's worlds. It is a control which cannot be exercised effectively without co- 
operative effort and proper organisation for work. The struggle with Nature differentiates man from the other animals, and is his hope of redemption from a natural poverty. The struggle is too stern for us to be able to afford to turn from it to spend most of our time in putting forth useless competitive work. The little world to which we are confined is too poor to yield more than poverty for the many while the many are stupidly scraping together a little for the few to enjoy. It is not a world of plenty, such as is often pictured by sentimentalists, in which Nature is bountiful and men naturally wealthy. It is a world of pain, in which a grim Nature stalks relentless, red of tooth and claw; a world so limited in resources that, until modern science had given us some degree of mastery, the majority of men were necessarily poor. To-day, with the endowment of science at our disposal, we know how to win plenty from an unwilling world. We know how, but even while we know, we neglect to put our hands to the necessary labour. To organise for work thus becomes the primary duty of our modern civilisations, and organisation for work is Socialism. A State of ill-informed but drilled servile units, under the guidance of a specialised bureaucracy, could doubtless do effective 


\section{STATE ORGANISED FOR WORK 83}

work and abolish poverty as we know it to-day, but it would not be the Great State we dare to dream of. The Great State can only be a nation of free men, educated to the full development and accentuation of their inherent inequalities, equal in point of economic independence and opportunity, understanding the necessity of continuous and unremitting labour, and therefore organised for work as the only means of escape from unnecessary toil. 


\section{III}

\section{CAPITAL AND IDEAS}

THAT capital is productive is one of the few points upon which the various writings on capital are agreed. One of the most thoughtful of modern economists, Professor Irving Fisher, in his " Nature of Capital and Income," after confessing it impossible to " attempt any reconciliation between concepts of capital so conflicting" as are exhibited in the various cconomic textbooks, points out that at least the definitions agree on a few points, and that the first of these points is that " capital is productive." Indeed, Professor Fisher might have gone further, and said that the point is usually accepted as axiomatic by economists, as, for example, by Professor Marshall when he refers to those "attributes of productiveness and prospectiveness which attach to all stored-up fruits of human effort." The most cautious utterance on the point is perhaps that of Professor Taussig, who in his " Principles of Economics," after dealing with the superior efficiency of a modern railway as 
compared with the old transport by packhorse and wagon, writes :

"This consequence has sometimes been stated by saying that capital is productive; a phrase which must be used with care. The strictly accurate statement is that labour applied in some ways is more productive than labour applied in other ways. Tools and machinery, buildings and materials, are themselves made by labour, and represent an intermediate stage in the application of labour. Capital as such is not an independent factor in production, and there is no separate productiveness of capital. 'When, in the following pages, the productivity of capital is spoken of, the language must be taken as elliptic, expressing concisely the result of the capitalistic application of labour.",

Here is exhibited some striving to get at the underlying truth, and if that underlying truth is not plainly stated, we may at least congratulate Professor Taussig on the avoidance of question-begging in this very important connection. The usual facile process is, as in a newly published primer on political economy designed to start anxious students on the right road, to term capital " productive," in the assurance that the student will as fully accept the adjective as though he were re- 
minded in passing that the sky is blue. Let us consider what underlies Professor Taussig's very true statement that " labour applied in some ways is more productive than labour applied in other ways."

The railway, to use Taussig's own illustration, is more efficient than the packhorse and wagon. Exercised upon the railway, a given amount of labour is very much more productive than the same amount of labour exercised with the aid of packhorses and wagons. But a collection of packhorses and wagons is just as much "capital" as a railway. If, therefore, capital were really productive, $£ 1,000,000$ worth of packhorses and wagons ought to be just as productive as $£ 1,000,000$ worth of railway. But they are not nearly as productive, and the difference between the productiveness of $£ 1,000,000$ worth of the old transport capital and $£ 1,000,000$ worth of new transport capital is that the new agency is the expression of clever ideas, and that is the essence of the matter. It is not capital which is productive, but ideas which are productive. Capital is merely inert material necessary to the carrying out of ideas. The idea is the seed, capital is merely the soil in which the idea is sown, and labour is necessary to prepare and till and maintain the 
soil in such condition that the seed may produce its kind.

It will help us to sce the untenable charactcr of the proposition that capital is productive if we refer once more to the comparative efficiency of a railway on the one hand and of the packhorse and wagon on the other hand. Let us suppose that it is required to carry a given quantity of goods, let us say $\mathbf{2 5 0 , 0 0 0 , 0 0 0}$ tons of coal, in the United Kingdom in a year, and let us suppose that capital is applied to the task. First of all let it be applied to purchasing and establishing throughout the country a transport system by packhorse and wagon. It will at once be realised that the amount of capital necessary would be enormous. British roads would exhibit one constant succession of packhorses and wagons bearing coal about the country. Next let capital be applied to establishing railways to do the same amount of work. In the long run less capital would be required, the productiveness of the labour employed would be much greater, and the price of delivered coal would be far less. Thus, capital as capital is not only not a producing agent, but as this illustration shows, an enormous amount of capital may be employed and yet yield the labour exercised upon it a very small 
return. The change from packhorse and wagon to railway does not mean any change at all in capitalism per se; it simply means that an inferior order of inventions is discarded and a superior order of inventions adopted in its place. Your packhorse and wagon is as essentially capital as is your locomotive, and if it is productive of little, it is simply because it embodies a poor idea; your railway produces much, not because it is capital, but because it is the embodiment of a great idea.

The vagueness and futility of conception embodied in so much of the writings that are described as "economics" arise from the unfortunate dissociation of economic thought with physical science. A book is written on the nature of capital-that is, about the nature of material things. The first thing the economic writer does is to put aside as unworthy of discussion the physical properties of matter, and to assume that for his purposes material commodities are not only lacking in known physical properties, but that they possess certain other physical qualities which demonstrably do not exist.

In the first place, capital is assumed to be unwasting, and in the second place it is assumed to be gifted with reproductive powers. These are very convenient assumptions for the 
moneylender, but for society they are as maleficent as they are childish and absurd. Physical science has not yet established what matter is, but it has established the conservation of matter. This, however, is a very different proposition from the conservation of capital. Every known element, as soon as isolated by man, begins to form combinations with other elements and to change its character as a material commodity employable by man. As soon as man constructs a manufactured article, the process of recombination of elements, which we call decay, sets in, and the article more or less rapidly, sooner or later, perishes, whether it be a house or a locomotive or a tool or a machine.

'What we mean by "capital" is a store, at a given point of time, of certain material commodities, and what we also mean by capital is that, at any given point of time, a certain store of material commodities has been accumulated which nature will forthwith begin to devastate and destroy. And yet your " economist" flies in the face of physical science, and sets up a concept of capital as something which is static, permanent, and indestructible-something which breeds, not corruption and decay, as physical science teaches, but wealth, i.e. other useful com- 
modities, which is a stupid "economic" untruth.

There are two, and two only, reproductive powers in the world.

The first is the reproduction of species in the sphere of organic life. This may be, and is, aided by intelligent labour throughout the world, men having discovered how to aid the germination of seed, how with the crops so obtained to rear great herds and flocks, and how, by careful selection of stocks, to improve the breeds of both plants and animals.

The second is the reproduction, in the sphere of the inorganic, of commodities shaped or arranged or selected by the employment of intelligent labour. In the thousands of years during which men have been sufficiently intelligent to shape and combine materials, a great body of lore has been accumulated, consisting of the inventions of what is actually an army of clever people, but relatively a tiny fraction of the thousands of millions of human beings who have lived during those thousands of years. In the quite recent history of mankind, the discovery of the use of Power has made it possible to devise and employ machines, and this has made it necessary to frame larger and more complicated tools. These machine tools, however, as masses of inert matter, have 
no power of reproduction. What is reproductive in them is the ideas they embody. The intelligent employment of those ideas gives us the fruit not of capital, but of genius.

Whose then is the genius, and whose is the fruit? The greater number of the inventors are dead, and our Patent Law puts a very short term indeed to the power of an inventor to draw fruit from his invention, however clever he may be, and however much his great idea may have added to the wealth of the country. In short, the ideas which are the seed of wealth are common property. They do not belong to those who possess capital ; they are the common inheritance of all mankind in this and every country. The familiar words, "All can grow the flowers now for all have got the seed," have a profound significance for a modern society, if it will make itself acquainted, not with the obscurities of a pseudo-science, but with the magnificent work which has been accomplished by the real sciences.

As things are, the common people are dependent upon the well-to-do for the use of the common stock of ideas, simply because the great modern reproductive ideas demand the accumulation and shaping of great masses of inorganic matter. But, as John Stuart Mill 
wrote so many years ago, it is capital and not the capitalist which is necessary, and it is quite unnecessary for the British people, or any other intelligent people, to be dependent upon a small body of moneylenders for the employment of those reproductive ideas which are the basis of modern wealth. The nation can easily subscribe and employ capital to be embodied in the furtherance of any idea it considers worth pursuing, whether that idea be the building and maintenance of a Navy, or the building and maintenance of a porver system, or the building and maintenance of beautiful towns. For practical purposes there remain few if any "secrets of industry" (I do not, of course, refer to the acquired skill of a craftsman), but there are plenty of tricks of trade which frustrate the revelations of physical science. The necessary ideas are ours, and can be employed in brecding their kind in truly economic productiveness whenever we elect to do so. 


\section{IV}

\section{I.AND IN RELATION TO BRITISH WEALTH}

§ 1. Land and the Industrial Revolution

THE wealth of modern Britain is not based upon British land. This is true of land in its ordinary meaning-of the surface of the country, and of the more or less cultivable soil or integral rock which forms its superficies. It is also true of "land" as the term is used for the confusion of thought in the many dismal treatises on economics, in which we are gravely told that "land" means " any free gift of Nature." The greater part of British wealth is based neither upon land in its proper meaning nor land in its pseudo-economic meaning. The British people are not an agricultural, but an industrial community, and the industry which sustains them as a great power in the world, and which alone can thus sustain them, is done upon bits of land which are a negligible portion of the British area, and consists of work performed for the most 


\section{LAND IN RELATION TO WEALTH}

part upon the gifts which Nature was kind enough to bestow upon other countries, but so unkind as to deny in sufficient measure to the British Isles. The only free gift of Nature which exists in the United Kingdom in abundance, and which is supremely valuable in industry, is coal, but so little is this a gift, that by the time coal is won and brought to the surface by arduous and dangerous work, and with the aid of much capital, it may be said to be a product and a symbol of the defiance of Nature.

In the United Kingdom, as indeed in any of the "old" countries of the world, work upon land in the sense of cultivation of the soil can only support a considerable population upon terms of comparative poverty, and then only upon condition that the population gives itself to hard and incessant toil. This is true whatever the form of land tenure, whether the communal ownership of the old Russian mir, the large ownership of the United Kingdom, the peasant proprietorship of France, or the metayer system which so largely obtains in Italy.

In an agricultural population-of the sort we are considering; the rapid exploitation of native fertility in a Canada or an Argentina is a different case-wealthy men can be but 


\section{THE INDUSTRIAL REVOLUTION 95}

few, and while the world as a whole chiefly lived by agriculture, wealthy men were, in practice, few. It needed tribute from a considerable agricultural district to furnish forth one single rich family, and what they took to make them rich, if distributed amongst all those from whom they took it, would scarcely have served to alter perceptibly the condition of the poor. In the United Kingdom to-day, the number of rich men who are sustained by agricultural rents is comparatively small. Indeed, the rent of British agricultural land as it stands is a very small proportion of the National Dividend, while that part of it which is paid for the free gifts of Nature-i.e. the prairie value of the United Kingdom-is too small to be worth consideration.

Thus it was that in the middle of the eighteenth century, at the turning point which witnessed the transformation of Britain from an agricultural to an industrial country, the nation stood at the parting of the ways between poverty and riches; between a stationary population and a rapidly increasing population; between national stagnation and national advance. The translation from agriculture to industry meant the translation of a state with an uncertain future into a state with enormous 
powers of development. The change, of course, was wrought by the use of coal. It began to be realised that the getting of coal meant the getting of power and the getting of wealth. The necessity to pump out of coalmines the water which impeded the workings was the direct cause of the British inventions of the steam-engine and the locomotive, and of others from these derived. The fact that Britain was the first of the few great coal nations to put her coal to economic use was the secret of her rapid comparative advance. The marvellous changes wrought in the eighteenth century by the use of coal changed profoundly the character of the British economy. It turned a backward nation into a leader of industry. It raised the population of England and Wales from the 6,000,000 of 1750 to the $9,000,000$ of 1800 and the $36,000,000$ of to-day-36,000,000 who would be scattered to the three corners of the world if coal now failed us.

So little are these truths realised in 1914, that we are sometimes invited to turn our thoughts from the real cause and present, if not abiding, foundation of the national prosperity to a vain attempt to build British wealth upon land. I hear British workmen invited to turn from the Power which alone 


\section{THE INDUSTRIAL REVOLUTION 97}

can provide them with wealth to the Spade which can only provide them with poverty. I see earnest men in all sincerity putting from their minds-if ever it entered their mindsthe only means by which the United Kingdom can remain a wealthy nation, and turning to a vain attempt to build national welfare upon "work on the land."

In these perverse imaginings, no small part is played by the false conception that we import nearly all the food we eat. The man in the street has become firmly convinced that nearly all our food comes from abroad. Politicians and publicists frequently commit themselves in writing and in speech to the statement that nearly all our food is imported. What are the facts of the case? We import into this country in a year (circa 1913), under the heading "Food, Drink, and Tobacco," about $£ 260,000,000$ worth of produce. Is it imagined that this consists entirely of things which could be produced under any circumstances whatever in the United Kingdom? As a matter of fact, if we subtract the tobacco and the drink and the tea and the rice and the oranges and the rest of it which cannot be conjured out of British land, and make allowance for re-exports, we find that the food imported into the United Kingdom in a 


\section{LAND IN RELATION TO WEALTH}

year is worth about $£ 165,000,000$. Do we feed our people on so little? Of course not. Some of us have been for years endeavouring to point out that we produce in the United Kingdom fully as much food as we import, of the kinds that we are able to produce, and at last we have the official Census of Agriculture to help us. It is shown by the Board of Agriculture that the food and other agricultural output of the United Kingdom in 1908 were worth $£ 210,000,000$. It should be clearly understood that these figures represent net production-all duplication is eliminated. It is clear, therefore, that the value of the food produced in the United Kingdom in 1908, say $£ 193,000,000$, was considerably more than the value of the food imported into the United Kingdom, as far as it consisted of things which are of a kind grown in the United Kingdom.

Now the possibilities of additional agricultural work in the United Kingdom can be made clear. It is perfectly true that a small proportion of our population gains its livelihood by agricultural work. It is also true that, small as the proportion is, it yet succeeds in feeding more than one-half of our 46,000,000 people. Therefore, if by whatever means we succeeded in growing all our food in the 


\section{THE INDUSTRIAL REVOLUTION 99}

United Kingdom (of kinds which Nature permits us to produce), we should employ twice the relative handful now employed in agriculture. But, of course, to grow all our own food would, in practice, be impossible, even with the aid of high Protective duties, as is found to be the case in Germany. Therefore, the possible extension of work "on the land" is a relatively small matter in the national economy. I hasten to add that I neither consider nor state that it is unimportant or actually a small matter; I am endeavouring to put the thing in its true perspective.

In general terms, the truth about agriculture as an industry, or group of industries, is that it affords an ever-decreasing field for employment. In the world as a whole, that is, the proportion of the people needed to grow the food of the world is ever-decreasing. That is an obvious consequence of the advance of science, and it would be more accentuated if science were more keenly devoted to agriculture than it is. Backward as agriculture is when compared with other industries, it is true even to-day that the work of a few men is sufficient to feed, and to supply organic materials to, a very large number of men, and in the time to come it will be true that the 


\section{LAND IN RELATION TO WEALTH}

work of a small group of men will be sufficient to feed a multitude. That being so, those who regard land as affording an unlimited field of employment are not only believing what is untrue, but what is the very reverse of the truth.

It is the consequence of the truth we have stated that we find rural depopulation manifesting itself not only in the United Kingdom, but in every civilised country. Here are some facts on this head:

Advance of Urban Populations

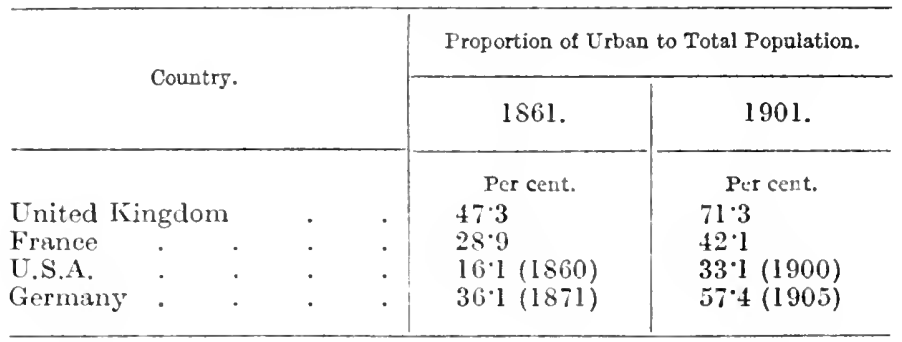

We see that cren in France, a land of peasant proprietorship, where men are so often tied to hard labour on the land under uneconomic conditions, the urban population rose from 28.9 per cent. of the whole population in 1861 to $42 \cdot 1$ per cent in 1901 ; it is now about 45 per cent. In Germany the urban population is now over 60 per cent.; that is to say, thus early in her modern indus- 


\section{THE INDUSTRIAL REVOLUTION 101}

trial advance, as large a proportion of the German people are living in the towns as was the case in the United Kingdom as recently as 1881, and that in spite of high Protective duties imposed by the German Government with the avowed object of preserving the rural population.

If we have regard to actual and not to relative decline of rural population, then it is again necessary to correct errors which have unfortunately gained currency. It is commonly believed that the agricultural population of England and Wales has declined by about one million in the last fifty years. Thus Mr. Chamberlain, at Welbeck on August 4, 1904, reflected this belief when he said of our agricultural population, "if you go back for fifty years it has decreased by something like a million." This million is a myth; as much as one quarter of it is accounted for by the fact that in 1871 our Census authorities wiped out, by a single stroke of the pen, 250,000 agricultural workers by excluding farmers' female relatives who had hitherto been included under that head. A very large part of the remaining decrease is accounted for by the happy fact that women no longer slave in the fields as they used to do in the old days in this country, and as they still unhappily do 


\section{LAND IN RELATION TO WEALTH}

on the small holdings of the Continent. Lord Eversley has shown, in his paper read to the Royal Statistical Society in 1907, what the real decline in male agricultural employment in Great Britain has been. In 1861 there were 1,657,000 male agricultural workers; in 1901 the number had been reduced to 1,236,000. The figures for England and Wales alone are : $1861,1,448,000 ; 1901,1,079,000$. Here are the valuable figures in more detail :

Great Britain : Decline in Male Agricultural Employment (Lord Eversley)

\begin{tabular}{|c|c|c|c|c|c|c|}
\hline 1861 & $\begin{array}{l}\text { England and Wales } \\
\text { Scotland }\end{array}$ & - & . & $\begin{array}{l}\text { Men } \\
\text { Boys } \\
\text { Men } \\
\text { Boys }\end{array}$ & $\begin{array}{r}1,121,000 \\
327,000 \\
163,000 \\
46,000\end{array}$ & \\
\hline 1881 & $\begin{array}{l}\text { England and Wales } \\
\text { Scotland }\end{array}$ & • & . & $\begin{array}{l}\text { Men } \\
\text { Boys } \\
\text { Men } \\
\text { Boys }\end{array}$ & $\begin{array}{r}942,000 \\
265,000 \\
136,000 \\
37,000\end{array}$ & 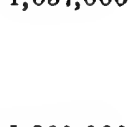 \\
\hline 1901 & $\begin{array}{l}\text { England and Wales } \\
\text { Scotland }\end{array}$ & & . & $\begin{array}{l}\text { Men } \\
\text { Boys } \\
\text { Men } \\
\text { Boys }\end{array}$ & $\begin{array}{r}876,000 \\
203,000 \\
122,000 \\
35,000\end{array}$ & $1,000,000$ \\
\hline
\end{tabular}

The recent publication of the Census of Occupations for England and Wales in 1911 enables us to get new light upon the subject of rural depopulation. The official census makes no comparison with the figures of 1901, but the following statement is accurate: 


\section{THE INDUSTRIAL REVOLUTION 103}

Agrioultural Employment, England and Wales. Males

\begin{tabular}{|c|c|c|c|c|c|}
\hline & & & 1901. & 1911. & $\begin{array}{l}\text { Increase or } \\
\text { Decrease. }\end{array}$ \\
\hline \multirow{6}{*}{\multicolumn{3}{|c|}{$\begin{array}{l}\text { Farmers and graziers . } \\
\text { Relatives of farmers working on } \\
\text { farms } \\
\text { Bailiffs and foremen } . \\
\text { Shepherds. } \\
\text { Farm servants : horsemen, cattle } \\
\text { men and ordinary agricultura }\end{array}$}} & 203,000 & 209,000 & $+6,000$ \\
\hline & & & & & \\
\hline & & & 89,000 & 98,000 & $+9,000$ \\
\hline & & & 23,000 & 22,000 & $-1,000$ \\
\hline & & & 25,000 & 21,000 & $-4,000$ \\
\hline & & & & & \\
\hline labourers & . & . & 584,000 & 622,000 & $+38,000$ \\
\hline & Total & . & 924,000 & 972,000 & $+48,000$ \\
\hline
\end{tabular}

This table, it will be observed, relates to England and Wales only, and to males only, and it does not include the machine-minders, etc., included in the figures of Lord Eversley. In considering it, it is necessary to remember that in 1901 a certain number of agricultural labourers were serving out of the country in South Africa, and that there is always a small element of error present in Census statistics. When these things are allowed for, however, it remains perfectly plain that the rural exodus was checked in the last décennial period. The number of male persons, farmers and employees, engaged in agriculture in England and Wales rose from 924,000 in 1901 to 972,000 in 1911, being an increase of 48,000 , or a little over 5 per cent. The facts will surprise those who have been stating that an enormous 


\section{LAND IN RELATION TO WEALTH}

migration from the country to the towns is still taking place.

It will be useful to give a comparison of the Census figures for male farm servants at the last four Censuses :-

Male Farm Servants: England and Wales Only

$\begin{array}{lllll}1881 & \cdot & \cdot & \cdot & 808,000 \\ 1891 & \cdot & \cdot & \cdot & 735,000 \\ 1901 & \cdot & \cdot & \cdot & 584,000 \\ 1911 & \cdot & \cdot & . & 622,000\end{array}$

The Census figures of 1911 are now (1914) three years old, and during that period the cxtraordinary efforts made by the British Dominions to persuade British rural workers to leave Britain, have continued and perhaps increased. It may be, therefore, that a renewed decline has set in from this eause.

When the statistical exaggerations are cleared out of the way, there remains a substantial decrease in agricultural employment, and that decrease has been chiefly caused, as we have already indieated, by the advance of science. The facts of the case have been well stated by Mr. R. H. Rew, in the Board of Agriculture's (1906) Report on the Decline of the Agricultural Population. After giving due weight to the cancellation of agricultural labour through the laying down of land to grass, the Report says : 


\section{THE INDUSTRIAL REVOLUTION 105}

"There is little doubt that the saving of labour on the $15,500,000$ acres which in 1901 still remained under the plough was in the aggregate greater during the twenty years than on the $2,000,000$ acres laid down to grass. Many expedients, other than actually stopping the plough, were adopted to reduce the labour bill. But while manual labour has no doubt been economised to some extent by curtailing some of the operations which require it, the main cause of its reduction is undoubtedly the extended use of labour-saving machinery. This is referred to by the large majority of correspondents in all parts of the country. With the exception of the self-binding harvester, which was introduced into this country in the early eighties, few machines for the performance of a specific manual operation have perhaps been invented since 1881 (unless milking machines, shearing machines, and, perhaps, potato diggers come within that category); but whereas twenty years ago labour-saving machinery was fully employed by comparatively few, it has now become almost universal on all holdings of sufficient size to make its use practicable. The substitution of mechanical for horse or hand power for fixed machinery -e.g. thrashing machines, chaff-cutters, pumps, etc. - has taken place largcly, although 


\section{LAND IN RELATION TO WEALTH}

it has made, comparatively speaking, little progress for tractive purposes. It may, indeed, be questioned if steam is so largely employed in the cultivation of the land as it was twenty years ago. But the displacement of manual labour arising from the greatly extended use of drills, horse-hoes, mowers, binders, manure distributors, and the like must have been in the aggregate very great, and probably to this, more than to any other single cause, the reduced demand for farm-labourers may be attributed."

Here is no isolated phenomenon; here is no economic factor peculiar to the United Kingdom. We have the expression of a truth which is world-wide in its application and which has a profound meaning in connection with the cconomics of actuality. Realisation of the limits of work upon land need not, of course, deter those who desire to improve agricultural tenures or to promote British afforestation. There is much that ean be usefully done in connection with land tenure, and much that must be done to rehouse the agricultural labourer, and to level up the glaring inequalities of wages as between Wiltshire and Durham. Further, there ean be no question that a good deal of what is now merely waste area in the United Kingdom 


\section{THE INDUSTRIAL REVOLUTION 107}

could be usefully clothed by the modern science of sylviculture. It is perfectly true that British land regarded as British soil could employ more people than it now employs. Actually the problems concerned are of great importance, and worthy of thought and even of enthusiasm. We shall do well, however, to recognise the strict limits within which we can operate in this direction, and the fact that at the utmost it is only a small proportion of the workers of the United Kingdom who can gain a livelihood by agricultural operations of any kind.

Britain is necessarily an industrial country while coal remains the main arbiter of industrial destiny, and as long as coal power reigns supreme, Britain can remain a relatively wealthy country based upon industry. Coal, because its bulk and weight render it so expensive to transport, can only be economically used in the place of its production. That, of course, is why the great coal countries are the great industrial countries, and it explains not only the emergence and rapid comparative advance of Britain after the eighteenth century, but the subsequent emergence and comparative gain upon Britain of America and Germany, as they, too, began to use their coal. Because coal can only be 


\section{LAND IN RELATION TO WEALTH}

economically used where produced, it is a magnet for the raw materials of industry, and from their places of production in the world to the coal-mines there pours an endless stream of raw materials.

Let us further consider the relation of land to the manufacturing industry which sustains British greatness. The United Kingdom is singularly poor in raw materials. As to the metals, she has fair quantities of iron and tin, and trifling or negligible quantities of zinc, copper, and lead. Of timber she has been content to divest herself, and if we started large-scale afforestation to-day, a generation and a half would have to elapse before the first considerable returns came in. For the vegetable fibres we are almost entirely dependent upon foreign supplies, the chief vegetable textile materials being exotic. As to animal products, we must necessarily depend upon sea-borne supplies for the chief part of the wool, hair, skins, hides, etc., which we need. There are many miscellaneous materials, such as rubber, gutta-percha, asbestos, etc., which are exotic. Apart from clay, limestone, salt, and china clay, we have to import something like seven-eighths of the raw materials upon which our industries are built. The definition of land as "the free gifts of Fature" in the 


\section{THE INDUSTRIAL REVOLUTION 109}

United Kingdom, therefore, is singularly beside the point, but it is probable that more students of economics are dosed with that for us depressing definition than are made acquainted with the conditions of British work. It is the gifts of other lands which we have to employ in Britain, and we can only get them by doing manufacturing work and by exporting (or lending, as when we invest exports abroad) British manufactures to pay for them.

As for mere surface upon which to do the manufacturing, that is a very small matter. The amount of land needed by four persons, assisted by several caddies, to play the arduous game of golf, is sufficient to house comfortably a number of great manufacturing businesses. Upon the piece of land needed for a tennis court, a factory of considerable dimensions can be erected. All the factories and mills in the United Kingdom, put together, occupy a negligible fraction of the area of the United Kingdom, and would need very little more even if they were rebuilt in a more efficient manner than now obtains. In short, the part played by British land in British manufacturing is, relatively, an insignificant one, which is as much as to say that the part played by land in the greater part of the work of the United Kingdom is an insignificant 


\section{LAND IN RELATION TO WEALTH}

part. Thus, so far from it being true that the land question is intimately connected with British material progress, it is a conception which is utterly at variance with the facts of the case. Professor Marshall puts it that "land is but a particular form of capital from the point of view of the individual producer." He might have added that to the capitalist embarking upon a manufacturing business, the land needed for his operations is one of the most insignificant items in his capitalisation.

The pull of the landlord, as landlord, upon manufacturing industry is thus relatively small, and it is because of this that landlords have been disestablished in the United Kingdom as the chief possessors of wealth, and that their aforetime position of economic sovereignty has been taken by those who possess great masses of capital.

But while the industrial and commercial workers, who produce nearly the whole of the nation's wealth, require but little land upon which to perform their economic functions, land nevertheless plays an important part in their lives. One hundred thousand workmen at work need little land for a base, whether they are making textiles, or boots, or watches, or boiler-plates. The same one hundred thou- 


\section{THE INDUSTRIAL REVOLUTION 111}

sand workers at home need for living places a very considerable amount of space, and it is here that the land question assumes its chief importance in a manufacturing country.

Those who dream the idle dream of " back to the land," find noble inspiration in the restoration of rude vigour to a great people. They point to the debilitated townsmen, and they urge that unless our peasantry is restored, it bodes ill for the future of the nation. That " a bold peasantry, their country's pride" must be restored at all costs is the theme of many. I have given reasons for believing that you cannot turn back the economic tide, and that for good or ill British wealth is founded upon British industry, and cannot be sustained upon aught else. But is "a bold peasantry" the only sound basis of a healthy State? Need manufacturing industry be associated with physical deterioration?

I believe that there is a sufficient answer to this and similar questions. I believe that we can face with equanimity the fate which has changed England from a poor country, with a small struggling and stationary population, into a thickly populated country of (relative) riches and influence. We need not believe that physical well-being is only to be won out 


\section{LAND IN RELATION TO WEALTH}

of the incessant, unnecessary, and wasteful toil of petty agriculture.

\section{§ 2. Space and Health}

If we are sensible enough to face the unalterable facts of the case, we can ensure that within a very short space in the life of the nation it shall attain to such a condition of health and physical vigour as it has never before enjoyed. The path to that condition does not lead "back to the land" in the sense of neglecting the industries by which we live in a vain endeavour to manufacture more agricultural labourers. On the contrary, as long as so many well-meaning people are content to think vaguely and talk vaguely on this subject, we shall not be likely to set cur hands to the improvement of the lot of the main mass of the people, which consists, and must continue to consist, mainly of towndwcllers. Recognising the facts, and directing our energies in the light of them, we see that the problem of the restoration of physical well-being lies in the reconstruction of our towns. That reconstruction involves the social use of considerable arcas of land, not for the 
purposes of economic work, but for the purposes of social use and enjoyment.

The essence of the land problem, therefore, in connection with the conditions of a great industrial community, is the element of space. Our people must have space upon which to live healthily, or they will deteriorate. It is not so much that our towns are overgrown as that they are too thickly grown. The conditions as to area of associated or town life can nowadays be determined by the conditions of locomotion. This germinal idea needs to be always present in our minds. With rapid suburban electric locomotion for all classes, with the rapid spread of the use of the motorcar, the cycle-car, the motor-cycle, and the ordinary bicycle-the last-named of which can now be bought new for a few pounds, and second-hand for thirty shillings-it is possible for close association in point of time to be coupled with the thinning-out of industrial areas.

Consider the problem as a whole. We have now about $46,000,000$ of people in these islands, or about 9,000,000 families. The area of the United Kingdom is about $80,000,000$ acres. If, therefore, the people of the United Kingdom were housed at the rate of ten families to the acre-which I have seen amusingly described 


\section{LAND IN RELATION TO WEALTH}

as the "Garden City" rate-it would call for the utilisation of only 900,000 acres. If, getting rid of the absurdly inadequate conceptions of housing which now prevail among all classes-not by any means among the working classes alone-our people were housed at the rate of five families to the acre, and if in addition we assumed the existence of ample pleasure grounds, children's play-grounds, playing-fields, etc., to call for as much land again, we see that the amount of land required would be only $3,600,000$ acres. That is to say, if this were done, our towns would still be small dots upon the surface of the country - the amount of land employed would be relatively very small.

If we could attain to such rehousing, who can doubt what the result would be? Our towns would become sanatoria, with a deathrate of about 7 per 1,000 , which would mean a saving of over 300,000 lives a year-lives with which the British Empire might be peopled as it cannot now be peopled. The measure of the lives saved is also the measure of the health that would be gained. Within a few years of the accomplishment of the task, there would be growing up within our borders such a generation as the days of petty agriculture never dreamed of-a generation infinitely 


\section{SPACE AND HEALTH}

superior to the "bold peasantry" mourned by the poet. Here is a sphere of action in which the land reformer can find a wide outlet for his energies : how best to find ways and means to rebuild these towns of ours, and to change them from places in which disease is bred into places in which disease can scarcely arise. That is the main thing which should engage the attention and care of our statesmen. Unfortunately there is an almost complete lack of vision in the matter-the working classes are apparently content with sordid and ugly cottages, built thickly together in rows as though the sun were not, and as though the word architecture had no meaning. Those who build them think sixteen feet of "frontage" ample for a working-class family, and are so blind to the first principles of what ought to be a noble business as not even to understand the simple business proposition that to build houses thickly together wastes land in providing space for roads, and wastes capital in making roads. And the middle classes are hardly better off. Their town villas are ugly, vulgar, and pretentious, and have little more reference to utility or beauty than the working-men's dwellings. In London and elsewhere we see smart middle-class people content to live in flats which transgress every 


\section{LAND IN RELATION TO WEALTH}

law of health, and which rob of their vigour the few children that are permitted to come to life in them. It is doubtful whether it can be said that in all the country there are more than a few hundred thousand families whose homes are a credit to the intelligence of those who occupy them. The lack of driving force behind politicians in this matter relegates housing bills to the position of minor measures. We may get excited about Home Rule, about Disestablishment, about Franchise, about the House of Lords-even about Insurance-but we are quite incapable of getting excited about the question of making decent homes.

Let us complete our perspective view of the land question by summarising the considerations we have advanced. We sce the British people as essentially an industrial people who can only maintain their wealth and power by industry, and who can at the best employ but a small proportion of their number in work "on the land." As an industrial people we see them based upon the possession of fine coal resources, our coal power being exercised almost entirely upon foreign materials. As industrial workers we see them needing for their actual work very small and almost negligible areas of land. For the purposes of healthy, social life we see where their chief 
need for land arises-viz. as space upon which to make healthy homes. We may sum up the whole of the facts of the case by saying that, for the greater part of the British people, the land question is a home or housing question, and not a question of getting land for economic use. To the relatively small number of agricultural workers the land presents itself in the double aspect of a place of work and a home place.

I do not conceal my opinion that the proper social use of land in connection with the town extensions, which are of such vital importance to the future physical well-being of the nation, cannot be amply secured without an extension of the principle of public ownership. Situation is the fundamental attribute of land. It is difficult to see how the social welfare of the many can be conserved unless the use of area is determined with due regard to communal needs. Those charged with the government of towns should be compelled to prepare plans for future town extensions, and should be given wide powers to acquire-and aided to acquire-the areas of future cxtensions. I should like to see National Land and Housing Commissioners, aided by the best engincering and architectural talent of the country, helping and stimulating every town to map out the 


\section{LAND IN RELATION TO WEALTH}

new area of its future life and growth. I should like to think that, before the nation has written much more of its history, there will be a "new town" and an "old town" to every urban community in the country.

But it is a profound mistake to suppose that the housing question is settled when we have provided land. Having settled the question of space in which to live, it still remains to house the people. It is, of course, a simple arithmetical truth that in connection with the housing question cheap money is far more important than cheap land. Housing is mainly a question of capital, and while capital is flowing abroad to obtain the high rates of interest which new countries offer, we must not expect capital to be used wisely for social purposes in this country. Let us face the fact, and if we really desire to do the rehousing which is so eminently necessary-if we are to stay physical deterioration-let us have the courage to raise capital and to use it directly to achieve the object we aim at, recognising that in no other way will the required thing be done. As is shown elsewhere in these pages, the Census of Production Report proves that the new private dwelling-houses built in a year in the United Kingdom are worth something less than $£ 20,000,000$, 
and that, be it remembered, is the value of building for all classes. At that rate the houses of the masses will not be rebuilt within a century from this time-i.e. within a period during which the cream of our coal-mines will have been taken. If we do not intend to tackle housing on a large scale, we simply mock the working-classes by talking about the subject at all. The rack-renter of the towns is not a landlord, but a houselord-a moneylender-and some of the worst slums in London are to be found in areas where under old leases the landlord is drawing a nominal rental while the slum proprietor, who is merely one of the worst types of moneylender, is draving enormous rentals for accommodation which destroys body and soul. And we must not believe that we settle the housing question even by paying better wages; our best-paid workmen, notably our miners, are quite unable to command decent houses with their wages.

In our day the land question has bccome a capital question. There is "free land" to be had on the Western Prairic of North America, and any man may take up a grant of 160 acres. He will find it inadvisable to do so, however, unless he is supplied with at least a few hundred pounds' worth of capital, and even so he will be hard put to it to escape 


\section{LAND IN RELATION TO WEALTH}

the clutches of the moneylender, who is the master of modern civilisation. (It is noteworthy that the Government of Saskatchewan have just had to appoint (1913) a commission of inquiry into the evils of moneylending as practised in the Far West upon farmers who obtained their land for nothing. The Commission found that of mortgages in existence in Saskatchewan, only 9 per cent. were at a rate of interest below 8 per cent. while over one fourth were at 10 per cent. or more interest.) Thus also it is with an English farm or an English small holding. To set a man to work on land without a proper supply of capital is to condemn him to failure. It is useless to talk about regenerating agriculture unless we are prepared to set up a suitable credit system, and to improve transit facilities, which again means the employment of capital. In our day and generation, what a man wants is access to capital. Mere access to land is for the savage, and it is what the savage enjoys. 


\section{V \\ THE COMMON ACCUSA'TION}

T' occurred to me one night at the theatre, 1 when the play was Bernard Shaw's "The Devil's Disciple." I bought a program, for which the not altogether inadequate price of sixpence was charged. My sixpence went bang, and $I$ received in exchange a document chiefly consisting of advertisements, in which it is only fair to say that the names of the characters and the performers could be easily detected. The program seller appeared to be a very nice girl. As far as honesty could be written on the human brow, it seemed to be written on hers. My sixpenny program, and I took an interest in the fact for the first time, was fastened together with a tab, upon which was printed: "Please see that this Seal IS UNBRoken."

I suppose I had seen this device before, and on many occasions, but I had never really taken proper notice of it. You can, of course, see a thing a thousand times without taking 


\section{THE COMMON ACCUSATION}

notice of it, and, as has been so well pointed out by Mr. H. G. 'Wells, millions of people had for thousands of years boiled water in kettles and pots and pans before any man seriously took note of the fact that steam was a great force positively asking to be employed in the service of man. So with my sixpenny tabbed program. Whether it was the honest face of the girl, or what not, the document suddenly appealed to me with a great significance. I held in my hand, not a program, but an indictment of our society.

"My poor girl," I thought, " what have you done that you should thus be publicly accused of a desire to embezzle sixpence? Is it true, I wonder, that you want to embezzle sixpence? I would wager many sixpences that if I inadvertently dropped sixpence and you observed it, you would hasten after me with the coin." That is what I thought then, but I have since become better informed as to the kind of pay that is given to the bright girls who are attendants at theatres and other places of amuscment. A little while ago one of them told me that she got $9 s$. a week for attendance at a kinema theatre, from two until eleven, and that her fares cost her $1 s .6 d$. of that, leaving a net $7 s .6 d$., out of which, of course, it was necessary for her to buy some 


\section{THE COMMON ACCUSATION 123}

food between the hours of two and eleven. In the case of theatres proper, I am credibly informed that even less than this, or nothing at all, is paid, the girls being supposed to rely upon tips. And honesty being thus at a discount in one direction, who knows but what it may occur to the underpaid to "do" as they are done by?

The faculty of seeing the thing once acquired, I began to see it in divers places. I went to wash my hands at a railway station, and was waited upon by an excellent old fellow, who, in his declining years, had been given this opportunity of earning a meagre pittance. I do not say this as a special reproach to railway companies, for it is one of their virtues that they do not, as is the case in so many other industries, throw their aged workers on the scrap-heap. I paid my twopence and received my towel. The towel was surrounded by a band, and on the band was printed, "See that this seal is unbroken," There lay the pile of clean towels, each of them bearing its black-and-white accusation against the lavatory attendant, each of them designed to compel the attendant to produce twopence for each towel, and to elicit the help of the public to check the attendant on behalf of the railway company. 


\section{THE COMMON ACCUSATION}

And then there are the shops. Time was when you paid your money and saw it go into a common till, but now all is changed. On the counter, or just behind the counter of the store, is a gorgeous American contrivance-a cross between a typewriter and a composing-machine, with a dash of sodawater fountain. This monstrosity is a Cash Register. It is a fearful and a wonderful thing. It swallows your money and it delivers up change. The shopassistant, provided, like a convict, with a distinguishing letter or number, let us say A, approaches the Register, depresses the A key, and thus opens his own particular $\mathbf{A}$ till. Into this he puts your money and from out of this he takes your change. At the same time he taps money-kcys, which cause to appear, in colour by day and in letters of fire by night, the amount of your purchase, while the intelligent machine gapes up a receipt. If the shopassistant makes an error, the machine most surely finds him out. It stands, therefore, as a perpetual guardian of the purse of the store proprietor. The other day, when I passed the gorgeous emporium at which these glittering engines are sold, I called in and obtained two descriptive pamphlets. Each of them bristles with testimonials from grateful users. A chenist writes: "By the time I have 


\section{THE COMMON ACCUSATION}

paid for it actually, it will have cost me nothing, as it has considerably increased my profits." The secretary of a working-men's club says: "Our experience is that they are a necessity for clubs, as they give protection to one and all."

But the accusation is commoner still, and it reaches and touches not only humble people like shop-assistants and 'busmen and lavatory attendants, but great and reverend men. We accept it as a prime necessity of civilisation that every balance-sheet or statement of account should be "audited and found correct." There is no bank or insurance company, or limited liability company of any kind, the accounts of which are not minutely checked and counter-checked. We have the greatest belief in the honour and integrity of the men in charge of the concern, but it would be commonly regarded as folly if their unattested words of honour were accepted. Publish your balance-sheet, we say; make a public exhibition of your most honourable methods. Demonstrate to us what you have done with our money, and be careful above all to accompany your honourable declarations with a certificate from a chartered accountant that, when you say it, it is so. "Sure, he is an honourable man," but let him prove it with the aid of other honourable men. 


\section{THE COMMON ACCUSATION}

I wonder if it is true that people have grown less honest as the world has grown collectively richer. Time was when a 'busman took your fare, put it in his leather pouch, and gave you no ticket in exchange. I am not very old, but I well remember the coming in of 'bus-tickets, and of the corresponding "jumpers." He was an amiable type of man, the old 'bus conductor, who had a little time for conversation and badinage. He was delightfully human; the mechanical ticket-puncher, grim of visage, taeiturn of speech, and reticent of direction, had not yet been invented, or, should I say, evolved? I wonder if the old 'bus captains were dreadfully dishonest with the pennies! And shops there were, in the old days, that appeared to flourish without the aid of mechanical policemen. I wonder, again, did the proprietors suffer from their artless faith ? There has been a tremendous multiplication of checks and counter-checks in all grades of trade and commerce. I wonder if any one is happier therefor. This, I know, with a surety most certain, that there shall come a time when societies of men will find it possible to enjoy the fruits of eaeh other's labour without eternally suspecting each other. In the meantime, the common accusation is a common shame. 


\section{VI}

\section{THE LADDER}

UR Minister of Education told the House of Commons in 1913 that the Government would in due course propose educational reforms which would cost a lot of money, and that the Government was prepared to foot the Bill. On what is the money to be spent? The suggestion is, apparently, that "secondary" or "higher" education is to be fostered, with the purpose of making a "great broad track" from the elementary school to the University. The "great broad track" is, of course, our old friend the Educational Ladder, and the avowed purpose of the educational ladder is to enable the boy of ability, no matter how humble his origin, to " rise."

The Ladder idea permeates our educational system, and has infected all our thinking upon education. So successfully is the Ladder system practised, and so great is its hold, that Education as she is may be faithfully pictured by the following diagram : 


\section{THE BLACK COATS}

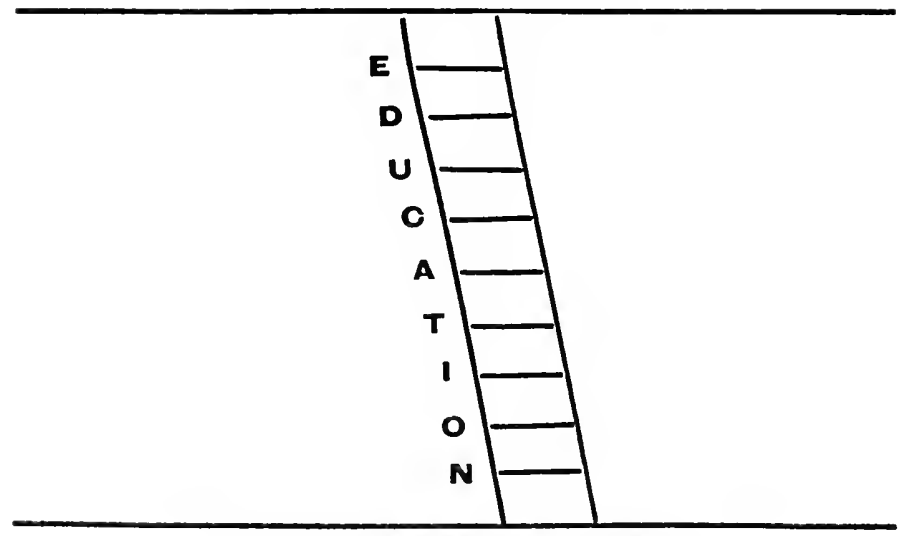

\section{THE COMMON HERD}

Such is our pitiful theory of applying education to the multitude. Elementary education is treated and regarded as a ladder, or series of ladders, to enable bright boys belonging to the working classes to make a happy escape from work into the effulgent regions in which women become ladies and men become gentlemen. This theory has been put into practice for so many years, that we have succeeded in draining out of the great body of the people an exceedingly large proportion of the brightest individuals, and of drafting them into what have become the overstocked regions in which men work on largely unnecessary and uneconomic tasks. In these regions crowds of the eminently respectable and genteel are 


\section{THE LADDER}

elbowing each other and suffering increasing discomfort, while their numbers are ever being swollen by fresh climbers of the Ladder.

It is part and parcel of this conception that more than the communication of rule-ofthumb knowledge is commonly considered to be more than the station of the manual labourer requires. 'We are careful, however, to provide scholarships, so that whenever the son of a manual workman shows any particular intelligence, he shall have the opportunity to climb out of manual work into the realms of the sublime. The bright boy, if he is wise, falls in with this system. If he has any "go" in him, he is able to see quite plainly that to be a carpenter means so much an hour for an uncertain number of hours in the year, and that the high-top-gallant of a bricklayer is to obtain "work" long enough to avoid dependence in age. The lesson is written so plainly for the bright boy to read, that he naturally hastens up the Ladder and joins the middle classes, in which, although so many fail, and in which, as I have said, there is so much jostling as numbers grow, there is yet the chance of a respectable climb.

The educational conception of which I have spoken naturally arises from the idea that it is necessary to divide the nation into two parts : 
(1) the toiling mass (commonly known as "the working classes"), and (2) a considerable, but relatively smaller, number of people who are to be completely absolved from manual labour, and who are to act as the officials and overseers of the toiling many. Amongst this relatively smaller section of the community there arises an increasing number of persons who obtain, sometimes through power of organisation and sometimes by inheritance, such an economic lien over the work of the many, that they become units of society absolutely free from both manual work and direction.

It is not unnatural that this relatively small second section should discuss public questions as though they chiefly concerned it as a section, and that the publie utterances of its members and of their organs in the press consciously or uneonsciously treat the great working multitude below as belonging to another world.

They are poor ideas and poor ideals, these of which I have spoken, and I refuse to believe that they can be permanent. Society cannot continue as a thing of two worlds, in which an increasing section of people divorce themselves from manual labour and despise those who practise it. I here plead again for a new conception of society in which all able-bodied 
adult individuals would do their share of what manual work needs to be done. Such a society would smile at the idea of the Ladder, and it would properly despise any man who, simply because he was a little cleverer or a little more artful than his fellows, sought to obtain the means of escape from the common obligation to work, and alleged that his fine brain needed for its development an entire absence of physical effort except in the form of golf.

The Ladder idea resembles nothing so much as a Hamburg lottery. From time to time we receive from abroad postal packets which seek to dazzle us with visions of $£ 50,000$ or so to be won by putting down a few shillings. The object of the lottery advertiser is to suggest to every person he addresses that the great broad track to a fortune lies open before him, and that he can put his foot upon the road by buying a ticket. In precisely the same way the Ladder is dangled before the masses of the people. Millions of poor parents are each, severally and simultaneously, assured that their children are to be given the opportunity to "rise." It is a prospect which in analysis means nothing for nearly all those before whom it is placed. It is, in effect, a lottery with a few prizes. It is deplorable 
that a working man should be encouraged, not to insist upon his child, in common with every other child, receiving a good education, but to consent to a poor standard of training for the majority, out of which by means of the Ladder a few are to emerge to climb upon the shoulders of their fellows. The average working man will do well to remember that his child is exceedingly unlikely to win a scholarship, but that his child is perfectly capable, as a normal specimen of his kind, to profit by the best training that can be given.

If we are going to spend more money on education, that money ought to be spent chiefly upon improving elementary education, not upon stratifying education. If we really want to put the children of the new generation upon the broad track, we can only do so by training each child, not by giving a mockery of training to the majority and a better training to a selected few. It is the mass of the people that needs cducation, not merely the bright and exceptional children. It should not be our aim to train the mass to be governed and a small minority to be governors.

I know a beautiful road leading out of London which constantly brings home to my mind education as it is. It is frequented by two kinds of boys-two distinct kinds of boys. 
The first consists of the pupils of a well-known school which possesses fine buildings and a magnificent playground situated in the road of which I speak. The boys are the children of well-to-do people, and it is a pleasure to see them at their games, at their drill, or running on a summer's day to their excellent swimming-bath. Their accents fall pleasantly on the ear, and their physical condition is obviously good.

The other sort of child consists of the children of the poor, who pass down the same road to the open spaces beyond; these are the products of poverty plus elementary "education." They are almost invariably undersized and thin, and a considerable proportion of them-an almost incredible proportionare in rags. They cannot speak their own language, and it is painful to listen to their attempts to express themselves. Their schooling is most obviously making no attempt to fit them to play a decent part in the world.

Is it to be our aim to train the mass of poor children to be the servants of the few, even while we assure their parents that they form a people who proudly rule themselves? As things are, our educational system is devised to fit the mass of the people to be governed by a specially trained few. The 
one sort of boy, the majority sort, is the child of the masses. 'The other sort of boy, the minority sort, is the child of the ruling classes and of their immediate private officials. The Ladder simply serves to train out of the one class into the other class a small number of the brightest children of the poor. Improving the Ladder simply means altering the stratification of a few more children at the general expense of the people at large. The people at large ought not to consent to pay for this stratification.

Let us face the facts. 'The operations of industry are coming to be more and more infused with scientific method. Rule-of-thumb is passing, and in some industries has already passed. 'The industry of the future will consist of scientific operations of great complexity. How is that industry to be carried on? Is it to consist of the performance of a mechanical routine by ignorant machine-minders directed by a few specially trained scientists, the minders to be drawn from an uneducated mass of people and the governors to be drawn from a comparatively limited class of people whose children are alone initiated into the meaning of processes.

If this terrible consummation is to be avoided, and we shall do well to remember 
that it is a consummation which is already partly achieved, there is only one thing for us to do, and that is to give every child, and not merely some children, a scientific education. The matter is of rapidly growing importance. The opening years of the twentieth century have witnessed an unparalleled scientific advance, and we are trembling on the brink of very great discoveries and achievements which, if our educational system remains where it is, will widen the gulf between those who know and those who do not know. Unless we consent to a universal education worthy the name, the mass of relative ignorance will increase. Each succeeding year will see a democracy with knowledge diminishing in proportion to the mass of knowledge, and in such circumstances an uneducated democracy may become a terrible danger to itself.

It is then highly necessary not to spend money upon processes of selecting and pushing up the Ladder a limited few. What money we have for education, and it should be our first business to find money for the purpose, should be spent upon educating the mass of children. By all means let us make a great broad track, but let it be wide enough for all to walk. Let us cherish freely the conception of children rising, but let not rising be inter- 
preted as the climbing of a Ladder out of one class into another. Let it rather be interpreted as the upward movement of an entire democracy, rising by virtue of the full education of the powers of each child that is born to the nation. 


\section{VII}

\section{THE RURAL WAGE}

\section{§ 1. Rural Wages as They Are}

\section{A LTHOUGH agriculture, considered as a}

separate unit, is still the greatest British industry, it is, as we have seen in these pages, small relatively to our industries as a whole. In 1907 the value of the products of British mines, mills, and factories, taken as a whole and ruling out all duplicated values, was worth about $£ 1,250,000,000$ at the places of production; a similar calculation of the value of the output of British agriculture, considering the whole country as one farm and again ruling out all duplications, gives $£ 210,000,000$. In short, Britain lives by manufacturing and not by agriculture. As has been shown, not only is our wealth derived as to the greater part from manufacturing, but by no other means could we sustain ourselves as a great nation.

Nevertheless, British agriculture remains an important, if a minor, part of our activities, 
and it employs in Great Britain about $\mathbf{1 , 3 4 0 , 0 0 0}$ persons (apart from 500,000 occupiers) and in Ireland 984,000 persons, including farmers. It is well that the nation, while never forgetting that its chief interest is industry, and that the mass of its people must consist of industrial workers, should not lose sight of the rural workers who feed onehalf of our people.

At the close of the days of Protection in this country the agricultural labourer was in a condition of abject poverty. Poor as conditions may be to-day, they are bright when held up against the background of that dreadful time. How much agricultural wages have

The Rise in Agricultural Wages

(Cash wages paid to ordinary labourers on 69 farms in England and Wales)

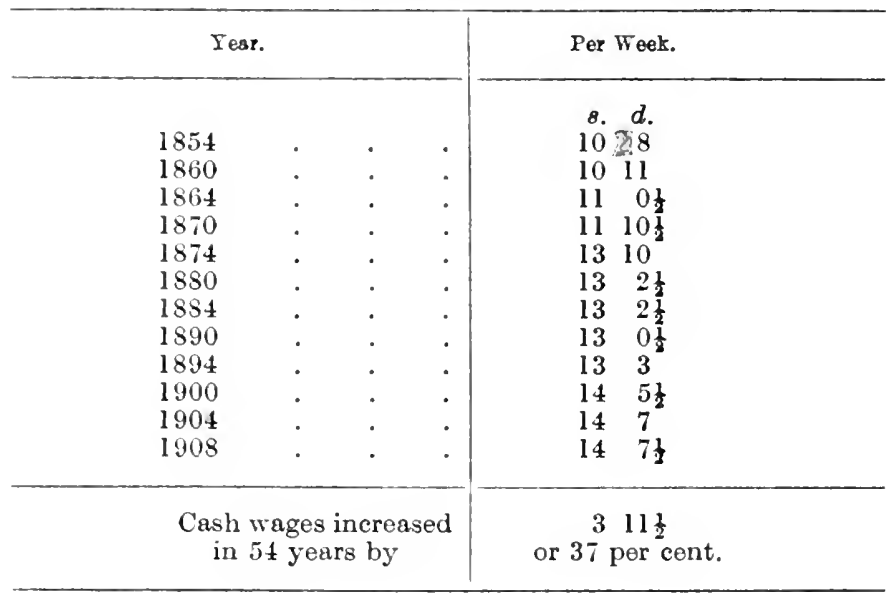


risen will be gathered from the foregoing brief statement, which is taken from figures compiled by the Board of Trade relating to sixtynine farms in England and Wales, and going back to 1854 .

It should be carefully noted that these figures relate to cash wages only, and that, in addition, the agricultural labourer usually receives some payment in kind in the form of a free cottage, or fuel, or produce, or what not. The cash wage alone is seen to have risen by 37 per cent. between 1854 and 1908, and as, in addition, there has been a considerable fall in prices since 1854, the increase in real wages has been much more than is expressed by this. Knowing, as we do, therefore, the rural poverty of to-day, we are helped to understand from what direful misery the rural labourer has emerged. We cannot say that he has passed from bad to good; we can only say that it has been a passage from bad to not so bad.

Let us now consider the agricultural wages of to-day in more detail. The Census of Wages conducted by the Board of Trade upon information voluntarily supplied-we have not yet had the courage to take a compulsory 'Wage Census-collected information from many thousands of farmers relating to tens of thousands 
of farm workers, and the number of returns secured was probably sufficient to give results of value. Here is a summary of the result for Great Britain :

Agricultural Weekly Earnings in 1907

(Including cash value of all payments in kind)

\begin{tabular}{|c|c|c|c|c|c|c|c|}
\hline \multirow{2}{*}{\multicolumn{2}{|c|}{ Ordinary labourers }} & \multirow{5}{*}{ 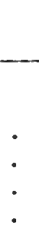 } & \multirow{5}{*}{$\dot{.} \cdot$} & \multirow{5}{*}{$\dot{\vec{\cdot}} \dot{\vec{\cdot}}$} & England. & Wales. & Scotlend. \\
\hline & & & & & $\begin{array}{rr}\text { 8. } & d . \\
17 & 6\end{array}$ & s. $\quad d$. & $\begin{array}{r}\text { s. } d . \\
1811\end{array}$ \\
\hline Horsemen. & . & & & & 189 & - & 198 \\
\hline Cattlemen . & . & & & & 191 & - & 194 \\
\hline Shepherds & . & & & & 197 & - & 205 \\
\hline All Classes & . & • & . & . & 184 & 180 & 197 \\
\hline
\end{tabular}

It should be carefully noted that these figures, unlike those in the first table given, relate not to eash wages alone, but to the total value of all payments received by the labourers, including the cash equivalent of all payments made in kind.

The result is to show that all classes of labourers earned on the average, in 1907, 18s. 4d. in England, 18s. in Wales, and 19s. $7 d$. in Scotland. The figures for ordinary labourers, it will be seen, are less than these. For Wales, owing to the small size of the farms and the miscellaneous employment of many of the workers, it is impossible to give separate figures for different classes of labourers.

The reader will at once be struck by the fact 


\section{WAGES AS THEY ARE}

that the average of Scotland is $1 s$. 3d. higher than that of England and $1 s .7 d$. higher than that of Wales. In further analysis some very remarkable results appear.

In the following significant table, taken from the same authoritative source, is shown the average earnings of agricultural labourers in a considerable number of counties in Great Britain, the figures, be it remembered, again referring not merely to cash wages, but to total earnings, including all truck whatsoever :

\section{How Agricultural Wages Vary}

(Total earnings, including all payment made in kind)

Average Weekly

Earnings.

20s, and over :

s. $d$.

Durham .

220

Northumberland . $\quad$. $\quad$. 216

Stirling . . $\quad . \quad$. $\quad . \quad$. 216

Fife . . . . . . 212

Lancashiro . . . . . . 210

Middlesex . . . . . $\quad 2010$

Nottingham . $\quad . \quad$. $\quad . \quad 204$

Derby . . . . . . 202

Yorkshire (West Riding) . . . 200

18s. and under 20s.:

$\begin{array}{lccccccc}\text { Surrey } & . & . & . & . & . & 19 & 9 \\ \text { Cumberland } & . & . & . & . & . & 19 & 8 \\ \text { Leicester . } & . & . & . & . & . & 19 & 7 \\ \text { Glamorgan } & . & . & . & . & . & 19 & 3 \\ \text { Argyll . } & . & . & . & . & . & 19 & 2 \\ \text { Stafford . } & . & . & . & . & . & 19 & 0 \\ \text { Yorkshire (East Riding) } & . & . & . & 18 & 9\end{array}$




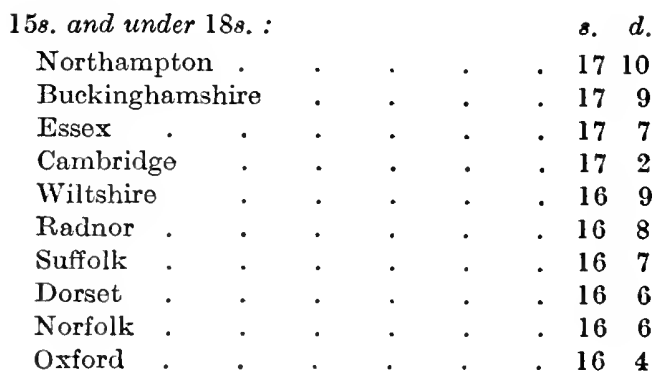

Here we have a list headed by Durham agricultural labourers earning $22 s$. a week, and footed by Oxfordshire agricultural labourers earning only 16s. $4 d$. a week. The extreme variation is thus no less than 5s. $8 d$. a week. This in the same small island, or rather in only one part of the same small island, at points removed from each other, as a glance at the map will show, by only about 200 miles!

How very true it is that one-half of the world does not know how the other half lives. Not only is it true that very few people in the towns are acquainted with the facts I have adduced, but I have not the slightest doubt that if one questioned the labourer in Dorsetshire, or Wiltshire, or Oxfordshire, or Norfolk, one would find him unacquainted with the fact that other agricultural labourers in the same country are getting over $5 s$. a week more than he is. We might do worse than try to 
make them acquainted with it, and to ask them to cudgel their brains as to how it is that such extraordinary differences obtain in the value of the same kind of labour in one and the same country.

Let us remember what it is that has led to the rise of about one-third in the cash earnings of agricultural labourers which has occurred in the last sixty years. That rise is due to the great growth of industry in the United Kingdom. Coal-mines have been developed, and our industries, which are mainly based upon coal, have grown with that development. Consequently, the rural population has had presented to it many alternative occupations. The growth of industry has been unequal throughout the country, because the distribution of coal is unequal. Where the coal is, there the factories and mills arise. The wealth produced by the growth of industry flows in some measure to all parts of the country, and parts even remote from coal feel its influence. Nevertheless, where the coal is, there the main work is done, there the main part of our wealth is produced, and from thence flow the fructifying streams.

Suppose we had had no coal. In that unhappy case England would have remained very much where she was at the middle of the 
eighteenth century, and agricultural wages in Great Britain would not have risen even to their present level, just as they have failed to rise to that level in coal-less Ireland, where the highest agricultural earnings, including all payment in kind, amounts to only $11 s .3 d$. per week as compared with $18 s .4 d$. in England.

The influence of coal as an economic factor has been supreme. Wherever neighbouring coal has afforded rural populations an alternative industry or industries, there the farmers have had to pay higher wages for labour. That, and that alone, is the reason why the farmers of Durham, where coal is rich, have to pay $22 \mathrm{~s}$. to their agricultural labourers, while the farmers of coal-less Oxfordshire pay only $16 s .4 d$.

It is remarkable at how short a remove the influence of coal in raising the agricultural wage ceases to have effect, and the fact throws a strong light upon human life and human custom as they are. It is but 200 miles from Oxford to Durham; it is an even shorter journey to other coal in the Midlands. The rural worker, however, rarely migrates within his own country. The agricultural labourer of Norfolk is not found offering himself either to the farmers or to the coal-owners of Lancashire. The man of Wiltshire rarely or never tears his roots out of his native soil 
to go to South Wales or to Staffordshire. The economists of the chair, who have made so many extraordinary mistakes, never made one more extraordinary than when they presumed the free mobility of labour within a country. If the agricultural labourer of Norfolk migrates at all, it is curiously not to go to Lancashire or to Yorkshire, but to follow the emigration agent to Canada or Australia. With some exceptional cases, such as that of the Irish seasonal migratory labourers, it is generally true that the rural worker does not offer his labour in competition at any very great distance. If it had been otherwise, and if there had been a perfect mobility of labour within the country, then the existing differences of agricultural wage would not have obtained.

Proximity to a port has also, of course, a considerable influence in deciding the level of the agricultural wage, and there are a number of minor influences upon which we need not dwell. For example, in Surrey we have the wage affected not only by the proximity of London, but by the fact that many men of means reside in that county and set up alternative employments and help to raise wages by demanding the services of gardeners, coachmen, grooms, and so forth. 


\section{§ 2. Rural Wages in Relation to Prices}

I now proceed to give some of the most interesting and important facts which we have to bring under consideration.

The prices of agricultural produce in this country are governed by our Free Trade policy, combined with the ever-growing efficiency of the enginecr in moving food products about the world. Cobden and his fellow workers gave us, as I have often pointed out before, nominal Free Trade, which is all that statesmen, as statesmen, can do. The statesman can only say: The ports shall be free. It is the engineer who does the rest, and the rest is the main part of the business. It was the engineer who lowered the price of corn by wiping out what was the equivalent of a high import dutyviz. the high cost of sea carriage. It was the great fall in freights, and the rapid exploitation of virgin fertility in " new" lands, again with the help of the engincer, that reduced foodprices, and the policy of Free Trade at this hour means nothing more than that a statesman says : I will not be so foolish as to deprive my country of the great advantages conferred upon it by the skill of the engineer in bringing us the produce of all the world. 
Free ports and the fall in freights brought down the price of agricultural produce in the United Kingdom to a level determined by world production and world demand. The price of corn at this hour is governed by the corn in being and available for shipment, or in prospect for shipment, all over the world.

The tremendous importance of these considerations in relation to our subject-matter will now appear. We have seen that agricultural wages in Great Britain vary greatly. We have now to add, to make the statement of the case complete, that:

Agricultural wages in Britain vary greatly in spite of the fact that there is a general level of food-prices throughout the country, food-prices being mainly determined not by home production, but by world production.

I have got out for the first time-I do not think it has been done before-a comparison of the price of wheat with the rate of agricultural earnings in the same places throughout Britain. The result, to which I direct the most serious consideration, is given in the table on the following page.

It will be seen that I have again taken the three groups of wage rates which $I$ gave on page 141, and taken three specimen counties in each group; any other selection would 
Price of Corn compared with Rates of Agricultural Earnings

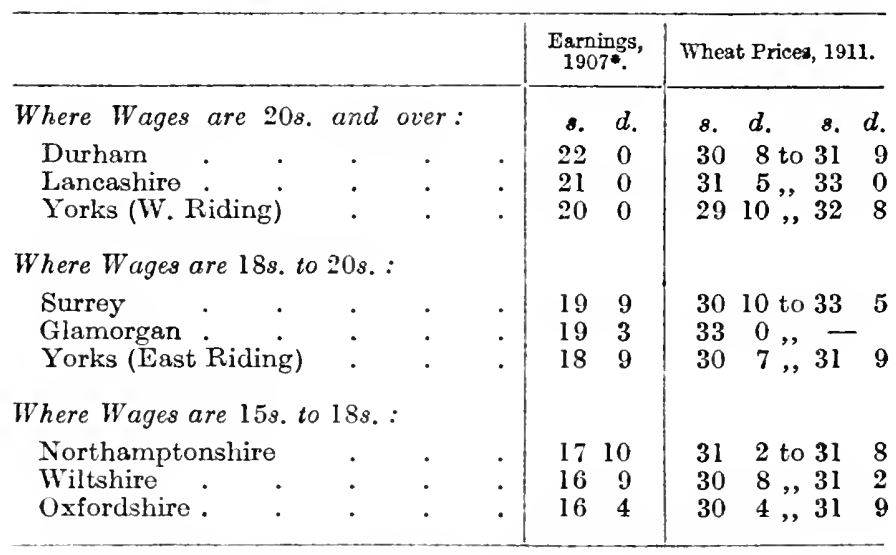

- The earnings for 1911 are not available, but are, of course, of precisely the same character in point of variation.

give the same results, and I have merely restricted the size of the table for the sake of clarity of expression. I have compared for each county the wages with the wheat prices, and what is seen to be the result? It is that agricultural roages are largely independent of the price of the food produced by the roage-earners.

Compare the proud head of the list, Durham, with the poor footer of the list, Oxfordshire. We see that the farmers of Durham get their $30 s$. $8 d$. to $31 s$. $9 d$. for corn, and find themselves able to pay $22 s$. a week for labour, while the farmers of Oxfordshire get almost exactly the same price for their corn-viz. 30s. $4 d$. to 
31s. 9d.-and yet pay their labourers only 16s. 4d. per week. Look in particular at the comparison between the West Riding of Yorkshire and the East Riding of Yorkshire. In the West Riding coal is plentiful, therefore the wage is 20s.; in the East Riding coal is not so plentiful, therefore the wage is only $18 s .9 d$.

The prices given are for British corn as sold in the local scheduled markets, and as officially reported to the Board of Agriculture. There is no doubt as to the authenticity of the information, and, indeed, from what I have already said, it will be seen that there cannot be any marked variation in the price of corn of the same quality throughout Britain, because price is governed by the supplies of imported produce. The small variations shown in the corn prices in the above table arise from minor considerations, such as quality, local supplies, and so forth. The general level is determined by foreign and Colonial corn.

Now the working of the main economic factors in producing the agricultural wage is almost invisible to those upon whom it operates. The changes take place over a considerable period of years, and in any locality it is only the rare thinking man who takes any trouble to understand what causes are working to 
produce certain effects. Just as it is true that the average uneducated man of the town rides in an electric tram without the faintest idea of how it works, or uses a telephone without understanding it, or is so guilty of misunderstanding a telephone as to thump it when it does not speak to him quickly enough, so, in a rural neighbourhood, farmer and farmer's man undergo economic transformations without understanding or even inquiring what factors are in operation. The agricultural labourer of Surrey is not only without knowledge of the fact that he carns very much more than the agricultural labourer of Wiltshire, but, even if acquainted with the fact, could not explain to you why it is so. What has " education," as she is written to-day, to do with such important things as these?

When, therefore, the farmer of - shire tells you that he cannot afford to pay a higher wage than 17s., including all truck, let us make no mistake as to his sincerity. He thoroughly believes what he tells you, and it is absurd to blame him for the sincerity of his belief. His representative in Parliament will probably sharc his belief, and you must not too hastily condemn the honcsty of his convictions on the subject. Nor is the farmer alone, of course, in believing that he can only 
pay such wages as have become customary he knows not how. Underpayment, unhappily, as we shall do well to remind ourselves continuously in these days, is not confined to agriculture, and I hope that none of us will forget that agriculture can be at the best only a subsidiary part of the national life in this country, and that it will not do to turn all our attention upon agriculture and to leave the masses of our people to decay in the awful towns that have arisen through other unfortunate economic misunderstandings.

The case as to agriculture is clear. We see that out of practically the same price for produce, farmers are paying all sorts of different prices for the labour they employ. Out of the price of the produce comes the profit which is divided between landlord and farmer, partly as rent (using the term "rent" here in its ordinary sense as the rent of the entire farm as a manufactured article) and partly as the fund out of which the farmer makes his own income and pays wage. It is manifest that if the prices can yield 22s. in Durham they can yield it also in Oxfordshire, for labour of the same quality. If there is anything, however, as even academic economists have been driven to admit, in the commonsense view that badly paid labour is dear labour, 
then it is more than probable that those who pay the better wages get better work, and that, of course, is only another point in favour of higher wages.

It is claimed here without reservation that the facts which have been adduced form an unanswerable case for a rural minimum wage. It is not suggested that an attempt should be made forthwith to raise Wiltshire to the level of Durham, or Oxfordshire to the level of Lancashire. It is plainly suggested, however, and indeed urged, that there is an ample margin in the price of produce for the local settlement of a reasonable minimum in cvery county.

\section{$\S 3$. Wages and Efficiency}

A better wage produces a better man. It is a dictum which is based upon experience, the experience not only of agricultural operations, but of industry at large. It has been well observed that the founder of Lancashire Trade Unionism deserves a monument from the cotton trade, because Lancashire Trade Unionism, by constantly improving the conditions of labour in the cotton trade, has com- 


\section{WAGES AND EFFICIENCY}

pelled efficiency in the trade, and compelled, therefore, a greater productivity.

It is ever the low wage trade which is inefficient. That is the simple seeret of the inefficiency of domestic work, considered as an industry. Why is it that we are only just beginning to see placed upon the market appliances to make domestic work decent and comfortable? Why is it that only at the beginning of the twentieth century have we seen any attempt to invent suction-cleaners and other appliances to assist women in their household work? The answer is that, in the working-class household, the woman is the unpaid woman-of-all-work, while in the servant-keeping household there has, until recent years, been an ample supply of dirt-cheap labour. How could anybody invent anything cheaper than a cheap girl ready to slave from morning till night for a small wage and a fraction of an attic? Just because in recent years, with increasing alternative better-paid employments offering for women, domestic servants have become more difficult to get, especially in the United States, inventors have been compelled to set their wits to work to devise appliances which otherwise would never have been thought of. So at last there is some hope of making domestic industry 
something better than eternal drudgery. To vary an old proverb, a high wage is the father of invention.

What is true of the triumphant Lancashire cotton trade, and what is true of domestic industry, is truc of every trade, and certainly not less true of agriculture than of other trades. In Scotland and the North, where the agricultural labourer is better paid, he undoubtedly gives better work. Let no one suppose that the $16 s$. to $17 \mathrm{~s}$. of Oxfordshire or Wiltshire or Norfolk or Suffolk commands the best work of the men who get these paltry sums, or that it produces men capable of making the best exertions. Do we expect good work from a horse when we deny him good food and good housing? I recently had before my eyes an example of the different work to be obtained by paying horses well and paying them badly. It was a job in which it was necessary to cart heavy loads over uneven ground. There came along the municipal cart, horsed by a wellpaid animal. The well-fed and well-housed horse surmounted the difficulties and took its load to the proper destination. 'Then came along the contractor's horse which, although paid at a much better rate than the Wiltshire labourer, was obviously not so well paid as the municipal horse. It failed to surmount 
the difficulties, and its load had to be deposited short of the place rcquired. One could have no neater illustration of the difference between high wages and low wages in their effect upon physiological actions.

But man is something more than an animal, and in his work not only physiological, but psychological influences tell their tale. The ill-paid man, the down-trodden man, the hopeless man, the man without spirit, is not only a man lacking brute force, but a man lacking in the power to overcome difficulties and to confront the problems of everyday life. With him the common task is a dull round. "To eat to work, to work to eat to gain the strength to work. So we go round the ruddy ring o' roses." I forget who wrote these lines, but they stick in my mind.

It is not yet widely understood that the cost of the worker is not the same thing as the cost of the work. It is the cost of the unit of work that matters. The Japanese cotton operatives, with their few pence a day, cannot rival the work of Lancashire operatives, who earn more in a few hours than Japanese operatives earn in a week. The absurdly low wages of the Japanese do not enable Japan to beat us in competition in the cotton trade. The 
much higher Lancashire wage amounts to a lower cost of labour per unit of work.

It is perfectly true that wages are an element in price, but they do not form an element which is directly proportionate to the rate of wages paid. On the contrary, cheap labour is a dear element in price, and dear labour is a cheap element in price up to the point at which the wage is high enough to produce the maximum of efficiency. As far as agriculture is concerned, we have seen the farmers of one part of the country paying nearly $6 s$. a week more to their labourers than the farmers of another part, and that this cconomie phenomenon is independent of price, sinee the price of agricultural produce in Britain is determined by world supply and demand, and not by British supply and demand only. It is clear that one of two things must be true, either (1) that the farmer of Oxfordshire can afford to pay up the balance of nearly $6 s$. a week, or (2) that because he pays $6 s$. less he gets less return per man in production. Whichever of these two hypotheses is true, or in whatever degrees they respectively share in the problem, the case for considerably higher wages in Oxfordshire is established beyond dispute. If Durham and Scotland were foreign countries, we should find the farmers of Oxford- 
shire declaring that fiscal policy or something of that kind enabled the farmers of Durham or Scotland to pay higher wages. As Durham is in England, fiscal nonsense cannot be dragged in in this connection.

The effect of the payment of better wages upon the master is no less marked than upon the man. Good wages are doubly blessed; they bless both those who give and those who take.

When a master in any trade is compelled to pay higher wages-no matter whether the compulsion be that his men have alternative employments offered them, or that they combine together in a trade union and demand a better wage, or that the law steps in, as under the Trade Boards Act, and says that he shall not pay low wages-the master has to look about him and mend his ways. Experience shows that he does not content himself with paying the higher wage forced upon him. He looks round to see what economies he can make to compensate him for the higher wage, and in the general case he soon finds means of effecting economies. The argument here is precisely the same as in connection with the costs forced upon employers by factory legislation in all countries. When you force a factory owner or occupier to provide proper 
ventilation, to whitewash walls, to provide sanitary appliances, to safeguard machinery, to provide washing appliances, to provide a meal-room or rest-room, what you do is to compel the man to help himself. Any sensible and really businesslike business manager makes his workpeople comfortable and safe, as a matter of course, and as a matter of business. It is the second-rate man, the foolish man, the thoughtless man, who fancies that a dirty, ill-equipped factory or business can be a paying proposition. When, therefore, the law compels second-rate and unwise men to do what first-rate and wise men do without compulsion, then the law is beneficial to industry.

Factory laws are a great incentive to efficiency in industry, but higher wages are an even better incentive. A man compelled, by whatever eircumstances, to pay good wages, respects those to whom he has to pay them, and does everything he possibly can to get his money's-worth by working for efficiency in every department of his business. $\mathrm{He}$ watches waste, he looks out for labour-saving appliances, he looks at every penny of cost that enters into the price of his goods. Invention is thrust upon him by necessity.

It is in the trades in which the highest 
wages are paid, therefore, that the greatest efficiency obtains, and it is in these that Britain finds herself most efficient. The trades in which our export power is strongest are those which are the best organised and the best paid. By the same token you shall know most surely which are the most successful countries. Pick out those nations where wages are highest, and you also pick out the nations which have the largest exports and the greatest industrial strength and competitive power.

It was lack of realisation of these profound economic truths that gave us the Railways Act of 1913 in fulfilment of a promise that if the railway companies raised wages they should be enabled to charge the wages to the public in higher prices. The Act and promise were alike based upon an elementary fallacy. The promise was made when the railway companies were paying an average wage to adult men of only about 25s. a week. You cannot on such a wage get the maximum of efficiency out of adult men. Therefore, any increase of wage paid by the railway companies would not raise their labour costs, but give them an increased efficiency in full or more than full repayment. Therefore, there was no need for either the promise or the Railways Act based upon the promise. In proof of which let us 


\section{THE RURAL WAGE}

observe that the German national railways have raised the wages of their workpeople fully 20 per cent. in the last ten years without raising fares and without raising freight rates, just as the British Post Office has raised wages while reducing charges. One of the cheapest motor-cars in the world is made in England by a man who pays a minimum wage, to his meanest workers, of about $£ 3$ a week.

Who can doubt the crying need for more efficiency in British agriculture, and how is it to be secured while those who work in it are remunerated so poorly? There is an absurd idea abroad that agriculture does not demand the same qualities of science or intellect that are demanded by industrial operations, and, indeed, it is true that science has not yet given anything like the same degree of assistance to agriculture that it has to industry. There are not wanting signs, however, that in the course of the next generation science will have atoned for this neglect, and will have changed agricultural operations very greatly indeed. The improvements in agriculture in the last two generations have been chiefly concerned with the work of the engineer in helping mechanical operations and providing mechanical appliances. Great things have been done in that direction, but in other direc- 
tions science has done comparatively little. The breeding of plants, the study of soils, the application of bacteriology, the use of electricity, the rapid cultivation of soils by explosives, these things will in the near future raise agriculture from one of the least scientific to one of the most scientific of trades. The conception of the "country bumpkin" has got to go, and will assuredly go. Rule-ofthumb in agriculture will have no chance in the future. Agriculture will have to be carried on by intelligent, well-educated, and wellremunerated people. It will not be a growing industry, because each successful application of science will reduce the number of persons required to grow a given quantity of food, and as the need for food and organic materials is strictly limited, the proportion of men required to grow produce must decline. That, of course, is a good thing for mankind and not a bad thing, since the fewer men required for one industry the more are set free for other industries, and the call for the product of other industries is, of course, without practical limit. When all imaginable improvements have been made in the growing of food, however, agriculture will always remain actually a great industry, if proportionately not such a great industry as it is in the world of to-day. 
The need for a higher agricultural wage emerges in whatever way we look at the problem, whether we have regard to considerations of wealth production or of humanity. Whether we consider the interests of the nation or of the individual, whether we look at it from the point of view of the farmer or of that of the labourer, we are driven to the same conclusion, that there is an unanswerable case for a better rural wage, and that it is a national interest that that better wage should be secured.

\section{§ 4. A Minimum Wage in Agriculture}

We now come to the consideration of the practical means of arriving at a minimum agricultural wage. What is required is a machinery which shall make it possible to have regard to all the practical circumstances of the case in any and every rural district.

In the first place, we have to remember that it is not in practice possible to force up wages to one general level for the whole country. It would not be possible to enforce the payment in every rural district of the rates 


\section{A MINIMUM IN AGRICULTURE 163}

now paid in the best-paid districts. We cannot hope by a single stroke to raise Oxfordshire to the level of Durham.

In the second place, our machinery must be such as shall make it possible in every district to have regard to the peculiar customs and methods of payment of the district. In this connection we have already seen that the agricultural labourer receives a certain part of his remuneration, varying from district to district, not in cash, but in kind. He may have a free cottage as part of his wages, or a cottage let to him at a nominal rent instead of its true rental value. He may have an allowance of milk or meal or cider or potatoes or fuel. As we have seen, the value of these various payments in kind was allowed for by the Board of Trade in arriving at the total earnings in all parts of the country.

In the third place, the term of engagement varies in different districts. In Scotland and the North there is a custom of engagement for a year, which is, of course, a guarantee against unemployment, and which enables a man to settle down in his cottage and to cultivate his bit of ground in some sort of security that he will reap where he has sown. In the South there is too often a mere weekly or even daily engagement, where the agricul- 
tural labourer is in no better case in point of security of employment than, say, the builder's labourer in the towns.

In the fourth place, piece-work is no stranger to many agricultural labourers. Here is an account, given by the late Mr. Arthur Wilson Fox, of the Board of Trade, upon earnings of individual agricultural labourers in 1903, as returned by their employers :

Farmers' OwN Reports, 1903

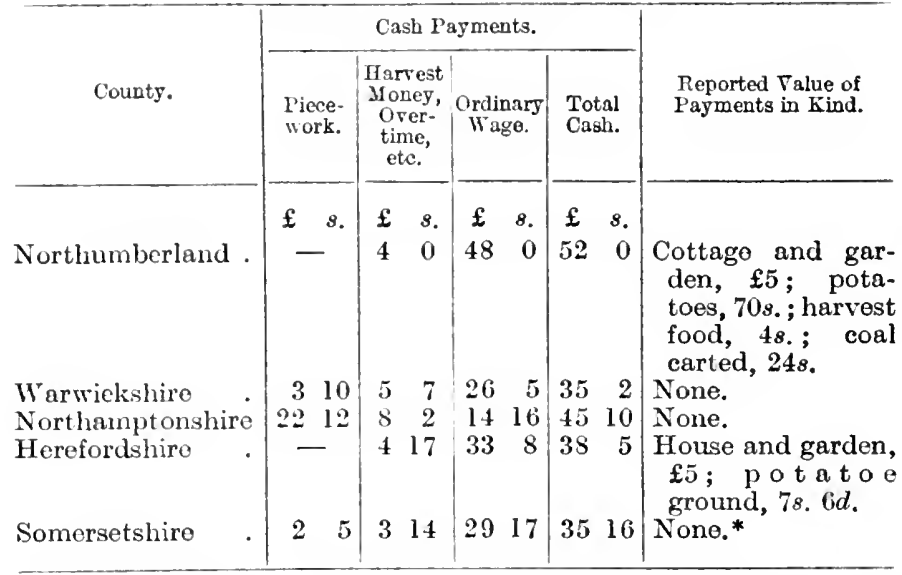

- Cottage and garden let to the labourer for $£ 2$ 12s. a year, but worth more, amounting to an allowance.

These examples are taken from widely separated districts, and the reader will see how greatly eustom varies. In the Northumberland case no piece-work is done, the man gets $\mathfrak{£ 1}$ a week in hard cash, and in addition a cottage and garden, $70 s$. worth of potatoes, 


\section{A MINIMUM IN AGRICULTURE 165}

a little food and drink at harvest time, and the free carting of his coal. The valuations of the worth of these items in kind are those of the farmer himself.

In the Warwickshire case there is a small payment for piece-work; the man gets only $£ 35$ a year, and he gets no payment whatever in kind.

In the Northamptonshire case the payments for piece-work are actually greater than the ordinary wages, and again there is no allowance in kind. As to Herefordshire, we have the case of a man who has no piece-work earnings apart from harvest money, and he gets a cottage and a bit of ground on which to grow potatoes, which the farmer puts down as worth a rent of $7 s .6 d$. a year.

In the Somersetshire case there are small piece-work earnings, and the labourer gets no allowance in kind save a cottage and garden let at less than their economic rental.

It is urged here that great as are the dissimilarities of wage and of custom in various agricultural districts, we have already established under the law a machinery quite adaptable to such circumstances, and, further, that we have seen in various voluntary Wage Boards difficulties of the same kind easily surmounted. The affairs of men, of course, cannot be ruled 
out into rectangles, and the Trade Boards system affords us a means of adapting the principle of the minimum wage to customs of widely differing trades or of widely varying districts.

When we talked of establishing Trade Boards for sweated workers some years ago, there were many who contended that the varying customs of trades made it inherently impossible to apply legal minima to them. We had to point out then that already, by voluntary agreement in many trades, the supposed impossibilities were surmounted. At the Conference on the Minimum Wage convened by the National Anti-Sweating League, and held at the Guildhall, London, in October, 1906, Sir George Askwith, then Mr. Askwith, pointed out how voluntary agreements of employers and employed had fixed minima in trades of considerable elaboration. He instanced the Nottingham lace trade, of which he had personal knowledge as arbitrator. I may usefully repeat what Mr. Askwith said :

"Perhaps you will forgive me for instancing a most elaborate inquiry I had to conduct in connection with the manufacture of lace. The due rate of wages in classes of work had to be found by joint request of employers and employees. The whole industry was entitled 


\section{A MINIMUM IN AGRICULTURE 167}

the lace weaving trade of Nottingham. It has three branches or sections-the plain net, the lace curtain, and the fancy laces. The plain net section is not so complicated as the other sections, but the curtain has eight different cards on which work is produced, and the fancy lace had twenty-one, and now has fifteen-thick thread laces, plain bobbin fining and Valenciennes, torchons, Maltese, blondes, Spanish, Chantilly, cotton loop, sprigs, and many others. There had to be taken into account the classes of lace being made, the number of points to the inch, the number of bars, and the length of the rack, and many other matters besides. The wages of each class and branch of laceworkers required separate consideration, and was discussed and fought word by word and line by line upon these numbers of cards."

As a result, Mr. Askwith concluded, "In few instances did dispute arise as to the amount of a minimum wage where such minimum was required."

And then, as now, we were able to point to the experience of the Wages Boards of Victoria. Who could imagine a more difficult trade in which to determine minimum rates than the underclothing industry? Yet even here the difficulties were finally surmounted, although 
they are obviously much greater than those connected with either the Nottingham lace trade or with British agriculture.

Further, in 1914 we are able to point to the remarkable success in the United Kingdom of the Trade Boards Act of 1909. It has succeeded in levelling up wages in a number of trades.

What is a Trade Board? As established by the 'Trade Boards Act of 1909, it is a body upon which employers and employed are equally represented, and its chairman is chosen from the members by the Board of Trade. The secretary of the Trade Board is also appointed by the Board of Trade. The members of the Board are either elected to it by employers and employed respectively, or they may be nominated by the Board of Trade. Provision for nomination was put in for the benefit of the workers in trades which consist of wholly unorganised and badly paid women. In the case of a trade like agriculture, the representatives of the men would be elected by the labourers, and the representatives of the employers would be elected by the farmers.

The Trade Board thus constituted, and equally representative of employer and employed, fixes minimum rates of wages for timework or for piece-work, and these rates they 


\section{A MINIMUM IN AGRICULTURE 169}

may apply universally to the trade, or to any special process, or to any special class of workers, or to any particular district or districts. Having arrived at its determination, the Trade Board gives notice of the fact, and six months later the Board of Trade makes an "Obligatory Order," which compels the payment of the determined rate, and in effect gives it legal authority.

Such a Trade Board may be truly termed a Wage Parliament. Imagine a Board so constituted in every district, set up to determine a minimum rate of remuneration for the labourers of the district, or to arrange varying minima for the various classes of labourers in the district. As soon as the subject was approached in this way, the difficulties which seem so great at a distance would appear in their true proportions as by no means insurmountable. As a local institution, the body would respect local custom, and have regard to all the various methods of payment. 'Timework rates or piece-work rates would present no difficulty, as is proved by experience here and abroad. Such matters as separate payment for harvest work would be susceptible of simple adjustment. With regard to cottage accommodation, there would appear to be no inherent difficulty in making due allowance in 
any given case. Similarly with regard to payments in bacon or milk or vegetables or fuel : it would not be more difficult to argue out what they should be counted for in value than for the farmer to return their value to the Board of Trade as we see in the table on page 164. Discussion of such matters would certainly have one happy result, and that is that where cottages are inadequate and insanitary, as they so often are, we should have them discussed in this local parliament of work as they had never been discussed before.

I think it is clear that the successful working of the Trade Boards system in relation to agriculture calls for the settlement of local minima by District or County Boards, as in the case of the Coal Mines Minimum Wage Act of 1912. Indeed, as we have seen, agricultural wages vary from district to district chiefly because of the unequal distribution of coal throughout the United Kingdom and the unequal richness of various coal areas. Just as District Boards were necessary in the case of the miners' minimum wage, so they are necessary in the case of the agricultural minimum wage. The Trade Boards Act of 1909 did, indeed, contemplate the establishment of District Trade Committees in certain cases; 


\section{A MINIMUM IN AGRICULTURE 171}

but what is called for in the agricultural case is a definite County Trade Board, and for this reason it would not be advisable to extend the Trade Boards Act in its present form to agriculture. With very little amendment, however, the Trade Boards Act could be so shaped as to be capable of application not only to agriculture, but to any and every trade in the country.

The question remains whether a minimum wage should be determined for the country as a whole-a minimum below which no County Trade Board should have power to make a determination. It is questionable whether this could be done while the matter of a general minimum wage remains in abeyance. I do not conceal my own view that, in view of the dimensions of the National Dividend, the time is ripe for the enactment of what may be termed a Physiological Minimum or Living Wage, which should be established in principle by Parliament, 'and in detail by a permanent Commission, set up by Parliament, which should revise its determination, say, every five years, and which should have regard to the cost of subsistence and to the wealth of the country as a whole. Such a Commission would, of course, have regard to the varying cost of living in different districts, and adjust 
its figures to the circumstances of each district. The recommendations of the Commission would bccome law after consideration by and with the approval of Parliament.

The physiological or general minimum thus arrived at would be a determination which would rule industry at large. In each particular trade, however, the minimum or minima for various classes of workers would be arrived at by Trade Boards after the manner of the Trade Boards Act, and these Boards would determine rates in relation to the productivity of each trade, having no powcr, of course, to make a detcrmination below the general physiological minimum.

Who can doubt that the general establishment of what I have termed Wage Parliaments would be a potent factor in relation to "labour unrest"-I will not say in allaying it, for I dislike the suggestion that labour unrest is a nuisance to be got rid of-but I will say in providing an immediate and a just tribunal of representative character which would be continuously at work to adjust the remuneration of labour in relation to the general wealth of the country, the cost of living, and the productivity of industries.

The argument that Parliament has no business to interfere with wages is only true 


\section{A MINIMUM IN AGRICULTURE 173}

in so far as Parliament is not a convenient tribunal to adjust the actual details of remuneration. It is not true as a denial of the expediency of the establishment by Parliament of the principle of the living wage, and of the establishment of a common-sense machinery to determine for each trade suitable minima for all the classes of workers employed in it. 


\section{VIII}

\section{THE MINIMUM WAGE IN PRACTICE}

\section{§ 1. The Trade Boards Act of 1909}

THE first direct Parliamentary interference 1 with wages in modern times has proved a triumphant success. A great principle has been vindicated; a great faith has been confirmed. It was as recently as 1909 that the Government wrote the Minimum Wage in the British Statute Book, and it was in January, 1910, that the Act came into operation. After three years' experience, the House of Commons unanimously confirmed the policy of the Act by extending it. Simultaneously proposals are coming from all quarters to carry the principle further still, and the cause of just remuneration is making a swift march. Yet it seems but the other day that many of us scarcely dared to hope that Parliament would listen to our proposals. I like to think in especial of the Trade Boards Act of 1909 as a monument to the labours and Parliamentary ability of the late Sir Charles Dilke. I grate- 


\section{THE TRADE BOARDS ACT OF 1909175}

fully remember that it was through him that I had the honour of serving upon the Home Work or Sweating Committee which was set up at his suggestion, and the recommendations of which were immediately accepted and carried out by the Government in the passing of the Trade Boards Act. Indeed, I am glad to say that the Government went further than the Select Committee. The Committee, most unfortunately, and in spite of the urgent representations of a minority, confined their recommendations, by a majority of eight votes to six, to the application of the minimum wage principle to sweated "home workers" only, and not to sweated workers wherever sweated. The Government wisely overruled this limitation.

The grateful thanks of those interested in the minimum wage are also due to Mr. George Cadbury, who, through The Daily Nerws and its staff, organised the Sweated Industries Exhibition of 1906, which did so much to direct public attention to the subject, and to prepare the way for the subsequent work of the National Anti-Sweating League, which, largely through the ability and devotion of its secretary, Mr. James J. Mallon, has secured the active and enlightened administration of the new law. 


\section{MINIMUM WAGE IN PRACTICE}

The Trade Boards Act established as a general legislative prineiple that, in any trade in which the rate of wages is "exceptionally low as compared with that in other employments," a Wage Board shall be set up to determine a minimum rate of wage, and that the determination arrived at by the Board shall have the force of law and be enforceable upon any employer in the trade under severe penalties.

Each Trade Board consists of members, representing in equal numbers employers and workers in a trade, sitting together with a smaller number of members unconnected with the trade and appointed by the Board of Trade. A Board may be set up for a trade as a whole or for a branch of a trade. A Trade Board has, in its turn, power to establish District Trade Committees to advise it as to the conditions of any partieular area, but it is the Trade Board and not the Distriet Board which fixes the minimum in any area. For Ireland separate 'Trade Boards are established.

Wherever possible, the employers and workers in any trade elect members to represent them on the 'Trade Boards, but the Board of Trade has power by regulations (properly challengeable in Parliament) either to provide for such election or themselves to nominate representatives. 


\section{THE TRADE BOARDS ACT OF 1909177}

Although the Act passed through Parliament without a division on principle-a fact as remarkable in its way as that the words " unearned increment" were writtcn in a Finance Act of Parliament by Mr. Asquith without challenge from any one, or that the Development Act, a measure of pure Socialism, passed the House of Commons with the glad approval of all parties-it was in the first place limited in its application to four trades-viz. :

(1) Ready-made and wholesale bespoke tailoring.

(2) Box making (of paper, cardboard, chip or similar material).

(3) Machine-made lace and net finishing.

(4) Chain making by hand.

Beyond this the Board of Trade is empowered to extend the Act by provisional order, but such provisional order has no effect unless and until confirmed by Parliament. So that the Trade Boards Act of 1909 set up a general principle, limited its immediate application to four specified trades, and, in effect, told the Board of Trade to come to Parliament again if they thought it advisable.

Not a moment was lost by the Board of Trade in administering the Act. Six Trade Boards were promptly set up, as follows :

(1) Chain making. 


\section{MINIMUM WAGE IN PRACTICE}

(2) Lace finishing.

(3) Paper-box making, Great Britain.

(4) Paper-box making, Ireland.

(5) Tailoring, Great Britain.

(6) Tailoring, Ireland.

The following examples show how the Boards are constituted in different cases :

The Lace-finishixg Trade Board

Members appointed by Board of Trade a 3

Nominated by Board of Trade to represent employers . $.4 . \quad$. 8

Nominated by Board of Trade to represent the workers . . . . . . 8

Additional members chosen by Board of

Trade: Employers . . . 2

Workers . $\quad . \quad$. 2

$\underline{\underline{23}}$

Chain Board

Mombers appointed by Board of Trade $\quad 3$

Elected by cmployers . . . . 6

Elected by workers . $\quad \cdot \quad \cdot \quad \cdot \frac{6}{15}$

$\underline{15}$

Now let us see what the six Boards, eovering four trades, have done. The following table is an official summary of the minimum timerates which have been fixed :

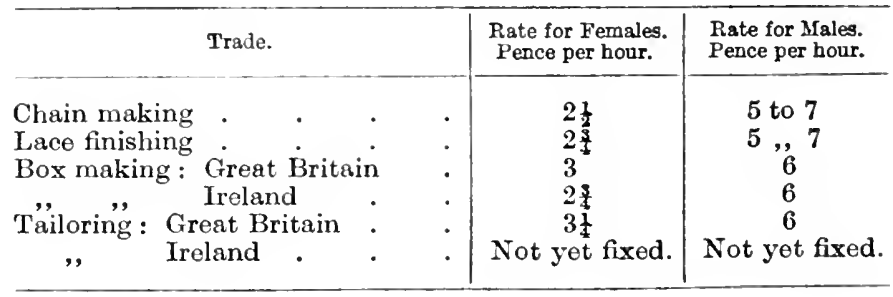


Let it be carefully understood what these rates mean. They are minimum time rates, to which, if piece-work rates are paid, the piecework rates must conform. They do not mean that the employer must pay by time and not by piece. A Trade Board must fix a minimum time rate, and may fix a minimum piece rate expressing the time rate. When a Trade Board establishes a time rate and does not establish a piece rate expressing it, the employer may either (1) himself fix a piece rate, which he must be able to show, if challenged, to be equivalent to the statutory minimum, or (2) he may apply to the Board of Trade to fix a piece rate for his employees.

\section{§ 2. What the Act has Accomplished}

The minimum rates which have been named may seem low, but they are very much greater than the rates of pay which obtained before the Boards were set up, and are, of course, susceptible of increase from time to time upon cause shown. In some cases the above rates represent twice as much, or more than twice as much, as was paid beforetime. Take, for example, the making of small 


\section{MINIMUM WAGE IN PRACTICE}

chains at Cradley Meath, a trade largely in the hands of women. In the old days a woman outworker got for making hand-hammered chains a few shillings a hundredweight. I have the authority of Mr. Mallon for saying that workers who received for making a certain class of chain $3 s$. $3 d$. per hundredweight, now get $6 s$. $6 d$. This particular change works out thus: Under the old conditions two hundredweights of chain yielded $6 s$. $6 d$. , less $2 s .6 d$. for forge rent and fuel, leaving net $4 s$. Under the Trade Board determination the woman now gets $13 \mathrm{~s}$. for making the chain, and again allowing $2 s$. $6 d$. for fuel and rent, she gets a net $10 \mathrm{~s} .6 \mathrm{~d}$., or an increase of 150 per cent. through the operation of the Aet. Many women making low quality chain now earn 12s. to $14 s$. a week, which is much more than twice their old earnings. In the men's trade-men, and a few exceptionally strong women, make strong chains by means of hammers worked with a treadle-proportionate results have been achieved.

The minimum wage at Cradley Heath was not brought in without some trouble with the employers. It is regrettable that some of the employers endeavoured to pile up a stock of chain made at the old sweated rates in the interval before the Board's determina- 


\section{WHAT THE ACT HAS DONE 181}

tion came into force. This interval arose from the fact that the Board of Trade under the Act can only make the minimum rate obligatory six months after the determination. Fortunately, the chainmakers, aided by the Women's Trade Union League and the National Anti-Sweating League, felt themselves strong enough to demand the new rates immediately. Upon this demand being presented, the employers locked out their miserably paid workers; but public sympathy was aroused, and after a few months of struggle the employers gave in and consented to pay the new rates before they became obligatory.

The Cradley chain trade is also remarkable for the first prosecution of an employer for failure to pay the minimum rate. It was a very bad case, the employer going the length of making false entries in his wages books in order to conceal his evasion of the Act. In the laconic words of the official report: "As the Court considered that the offences were serious, they imposed fines amounting to $£ 15$, with $£ 99 s$. costs; and in addition the defendant was ordered to pay to the workers

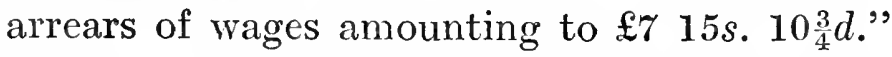
Section 6 of the Trade Boards Act fortunately provides that the amount underpaid must be paid up in addition to the penalty. 


\section{MINIMUM WAGE IN PRACTICE}

As a consequence of this series of events the workers have gained an entirely new spirit, and some months ago ( $\mathrm{I}$ write in May 1914) demanded that the minimum rates first fixed should be improved. After consideration the demand was acceded to, and the original minimum rates have now been increased by 10 per cent. Old prophecies of woe to industries called upon to pay better wages have, of course, been falsified by the Cradley Heath case. Although wages have been so greatly raised, and in some cases doubled, or more than doubled, the industry has prospered more and not less since the operation of the minimum. It is probably true that few employers know what wages they can afford to pay. That is why we get such extraordinary variations of remuneration in some tradesvariations which exist without any logical nexus with the quality of work, or strenuousness of work, or productivity of the trades.

Many of the Nottingham lace finishers, before the Trade Boards Act, were almost as badly off as the women of Cradley Heath, and the trade had the further complication that much of the home work passed through the hands of middle-women, who, themselves receiving a poor rate, sometimes sweated the actual workers very badly indeed. We may 
illustrate in this case how the minimum time rate of $2 \frac{3}{4} d$. per hour is interpreted by Board of Trade regulation in the shape of general minimum piece rates. The official notice relating to machine-made lace and net finishing reads as follows:

"The general minimum piece rates for the commonest quality of the following processes in machine-made lace and net finishing, other than the finishing of the product of plain net machines, shall, except in the case of warp laces, be as follows:

For Drawing, $1 \frac{1}{2} d$. per thread per gross yards for all threads.

For Roving, $\frac{3}{4} d$. per thread per gross yards. For Clipping, 1d. per thousand clips. Two cuts shall count as one clip.

For scolloping, $\frac{3}{4} d$. per dozen yards.

Stiffer or better qualities are goods finer than 40 inches to the double rack of 3,840 motions.

An attempt to meet the difficult question of the middle-woman was made in this connection by providing that where the worker fetches her own work from the warehouse, an additional rate must be paid to compensate her for her loss of time. There are few diffi- 


\section{MINIMUM WAGE IN PRACTICE}

culties in any trade which cannot be solved in practice by a Wages Board.

It is a happy thing for the public, as well as for the workers concerned, that the enormous trade of paper-box making should be brought under decent conditions. Paper boxes, to hold all sorts of things from boots to confectionery, have in the past been made in filthy and infected rooms, out of which the boxes emerge with an apparent cleanliness which is altogether belied by their true condition. I fear it cannot be said that the unhealthy conditions are swept away by the enactment in this trade of a minimum wage of $3 d$. per hour in Great Britain and $2 \frac{3}{4} \mathrm{~d}$. per hour in Ireland, but undoubtedly something has been done to mitigate an evil which has its punishments for the innocent consumer as well as for the guilty employcr and the sweated worker. I do not know whether it is fortunate or unfortunate that the white boxes, which are now used so commonly, cannot tell their pitiful history to those who use them.

As to the box trade, we have the evidence of the Earnings Enquiry of 1906 to show how badly a minimum wage was needed in the trade. It is shown by this Wage Census that, upon returns made by the employers themselves, and which are not likely therefore 


\section{WHAT THE ACT HAS DONE 185}

to under-state the rates paid, the average earnings for full time of the women employed was $12 s$. $3 d$. a week, and that nearly 25 per cent. of the women workers earned less than 10s. a week. The present minimum rates which the workers are about (May 1914) to attempt to raise are therefore above the preceding average.

The wholesale tailoring Board for Great Britain, as we have seen, fixed a minimum rate for women of $3 \frac{1}{4} d$. per hour and for men of $6 d$. per hour. Again the Wage Census of 1906 helps us to see how much the workers in this trade needed legislative assistance. According to returns made by employers, women working full time in 1906 earned an average of only 12s. 11d. per week. Of the women working power sewing-machines, 21 per cent. earned less than $10 \mathrm{~s}$. a week. Of the hand sewers and finishers, 38 per cent. earned less than 10s. a week. These figures, it should be remembered, refer not to young girls, but to women over eighteen years of age.

The minimum is now $3 \frac{1}{4} d$. per hour, so that in a fifty-one hour's' week the minimum earning would be nearly 14s. as compared with the old average of $12 s .11 d$. Like the rates in the other trades, the tailoring minimum is 


\section{MINIMUM WAGE IN PRACTICE}

not to stand at its original level and its increase is under consideration.

The minimum rates in the tailoring trade have only been in force since February, 1913.

In all the four trades scheduled under the Act of 1909, the Trade Boards have dealt with the question of learners, suitable minima being fixed for these in propcr relation to the minima fixed for adults. For example, in the lacefinishing trade, the rates for learners range from $5 s$. a week for learners of thirteen and under fourteen years of age, up to the full minimum rate, which is reached at between fifteen and eighteen years of age, according to years of scrvice.

It may be remembered that amongst the favourite points of objection to the minimum wage principle, the slow or ageing worker takes a high place. We are asked to pity the infirm worker, and not to ruin him by a minimum wage, which would lead to his dismissal. In practice, however, the point is not of any real importance. The Act of 1909 provided for it by authorising the Trade Boards to grant a permit exempting an exceptional person from the operation of the determination. It is of interest to note that so far the number of permits authorised is as follows : Lace finishing, 2 ; Box making, Great 


\section{WHAT THE ACT HAS DONE 187}

Britain, 24; Tailoring, Great Britain, 95. The aggregate of these special cases is insignificant when compared with the number of workpeople who were brought under the Act of 1909, for the number is officially computed at 200,000 workers, of whom about 70 per cent. consist of women and girls.

\section{§ 3. The Extension of 1913}

Thus, in about three years, the provisions of the Trade Boards Act of 1909 have been carried into effect, and the minimum wage set up in chain making by hand, lace finishing, cardboard-box making, and wholesale tailoring. In 1913 the early experience of the working of the Act, combined with the accumulating revelations of the Wage Census of 1906 , led the Board of Trade to propose to Parliament the extension of the Act in the manner contemplated by the measure itself. The Trade Boards Act Provisional Orders Bill of 1913 sought to confirm the addition of the following five trades to the schedule.

(I) Sugar, Confectionery, and Food preserving.

(2) Shirt making. 


\section{MINIMUM WAGE IN PRACTICE}

(3) Hollow-ware.

(4) Linen and cotton embroidery.

(5) Calendering and machine ironing in steam laundries.

The Bill was referred to a Select Committee, which recommended that the inclusion of the first four trades named should be confirmed, but that the last should be omitted. The reason for this unfortunate omission was not the merits of the ease. It appeared that there are laundries, in which other than steam power is employed, which were not sufficiently described by the term "steam laundries" used by the official draughtsman, and on this technical point the Provisional Order was opposed, and failed. 'This year (1914), however, the Board of Trade have promptly made another Order with a better definition, and I carnestly hope it will be found that laundry proprietors will not have profited by the delay. Laundry work is a humble oceupation which has come through the use of power machinery to be worked by large and small capitalists. We must not permit capitalist farming of the wash-tub to be done at the expense of women and girls. The priees we pay are high enough to afford a decent living. It is strange that for the getting up of a shirt we should pay as much as $4 d$. or $6 d$., and find 
it yield little to the woman who actually did the work, just as it is strange that we should pay five to eight shillings for the shirt itself, and find it yield so little to the shirt-maker.

The Wage Census (remember that it is based on returns made by employers and not by workers) shows that of the women calenderers who worked full time in 1906, 42 per cent. earned less than 10s. a week. Yet the employers of women, proved to pay wages as bad as this, are fighting hard against the inclusion of their trade under the Trade Boards Act. I heartily commend to every wearer of clean linen the spirit of the representations made to the Parliamentary Committee by the counsel employed by the capitalist washerwoman, and especially the tone of the questions which the counsel in question addressed to the Board of Trade representative. For example, when Mr. Barnes, of the Board of Trade, handed counsel the, extraordinary figures I have quoted, it was received with the exclamation, "This thing?" I think that "this thing" will prove too much for sweating laundry proprietors before this year has passed.

Let us take the four trades to which the Trade Boards Act was extended in 1913 and see what women earn in them. Last 


\section{MINIMUM WAGE IN PRACTICE}

year we had published a report on the wages earned in the four trades in 1906, the lapse of seven years between the date of inquiry and the date of report being explained by the fact that the Board of Trade has to work with a staff that badly needs enlargement.

With regard to cocoa, chocolate, and sugar confectionery, it is shown that women working full time earn on the average only $11 s .9 d$. a week, and that over 40 per cent. earn less than 10s. a week. This does not refer to girls, but to women over eighteen. As to girls, of those working full time, over 90 per cent. earn less than $10 s$., and nearly 19 per cent. under 5s. We plainly see, therefore, how well justified was the Board of Trade in proposing to Parliament that these workers should be protected by the minimum wage principle.

As to shirt making, it is shown by the Wage Census that 22 per cent. of the women working full time earn less than 10s. a week. The average earnings of all the women employed for full time was only $13 s$. $4 d$. a week, and one is constrained to wonder what becomes of the price we pay in the shops for shirts. One part of the answer is very quickly given, and it is that if you buy a shirt for $6 s$., fully $2 s$. represents the retail profit. As to the 
remaining $4 s$., it is quite clear that not very much can be represented by material, and in view of the fact that the women in the trade earn an average of only $13 s .4 d$., a very small part must be represented by labour. In general terms we may say that the final price given by the consumer has very little relation indeed to the wages earned by the producer.

In both the confectionery and the shirtmaking trades the Boards, though only a few months old (May 1914), have completed the first stage of their work and are about to issue proposals to fix in the confectionery trade a minimum of $3 d$., and in shirt-making a minimum of $3 \frac{1}{2} d$. per hour.

I am not able to give information of a definite character in regard to the wages prevalent in the hollow-ware trade, but there is no doubt that in some of its branches there is a considerable amount of underpayment, and women employed, in the industry in the Stourbridge district have lately had to strike to obtain a minimum wage of $10 \mathrm{~s}$. a week. The expressed intention of the Board of Trade is to deal with those branches of it in which women are mainly employed, and who are in many cases badly sweated.

With regard to linen and cotton embroidery, we have the sad report of the Committee of 


\section{MINIMUM WAGE IN PRACTICE}

Enquiry, presided over by Sir Ernest Hatch, which recently investigated this subject in detail. The Committee recommended that the Trade Boards Act be extended to the various processes of hand embroidery, fancy sewing, thread drawing, thread clipping, nickelling, ete., and to the machine-stitching of aprons and blouses in the North of Ireland, provided that the Aet be also applied to other parts of the United Kingdom where the processes are carried on. The report and evidenee make sad reading, and they fully justify the denunciations of outworkers' conditions in Bclfast by the courageous Medical Officer of that city. It must suffice to give a few of the particulars which were given in evidence by qualified investigators. Summarising the eases examined by three investigators, out of 125 thread-drawers employed by 12 firms, 29 earned less than $1 d$. per hour, 22 earned $1 d$., and 50 earned between $1 d$. and $2 d$. Of 140 thread-clippers employed by 13 firms, as many as 69 earned less than $1 d$. an hour, 36 earned $1 d$., and 22 earned between $1 d$. and $2 d$. Of 118 embroiderers employed by 13 firms, as many as 41 earned under $1 d$. an hour, 22 earned $1 d$., and 34 earned between $1 d$. and $2 d$.

One firm admitted in evidenee that they paid $\frac{1}{2} d$. an hour for embroidering pillow-shams. 
The Committee visited a factory and saw a young girl, a quick and expert worker, clipping tray cloths for a rate which brought her no more than $1 d$. an hour. At another factory they saw another girl thread-drawing a sideboard cloth. It took her twenty-three minutes to finish one cloth, and she earned $1 \frac{1}{4} d$. per hour. The Committee made many other careful enquiries and were perfectly satisfied, as were their investigators, as to gross underpayment in a large proportion of cases. Such are some of the conditions of labour in the capital of Ulster to-day, and the extension of the Trade Boards Act to cover the trades concerned comes not a moment too soon.

It will be perceived that without further legislation the Trade Boards Act could conceivably be extended to cover every trade in the United Kingdom. The words used in the Act are that the Board of Trade may make a Provisional Order, subject to Parliamentary confirmation, for any trade "if they are satisfied that the rate of wages prevalent in any branch of the trade is exceptionally low, as compared with that in other employments." "Low" is, of course, a relative term, and as the standard of living advances, the poverty line rises with it, and the conception of what is a "low" wage rises with it. It is to be 13 


\section{MINIMUM WAGE IN PRACTICE}

hoped that the national amour-propre on the subject of wages may be soon quickened sufficiently to bring within the scope of this beneficent and practical legislation a large number of industries. 


\section{IX}

\section{THE NEW DEARNESS}

\section{§ 1. Variation of Prices since the Eighteen-seventies}

THE rise of prices in the last fifteen years or so has been a phenomenon of farreaching importance. World-wide in its range, it has adversely affected wage-earners everywhere. In the United Kingdom it has undoubtedly proceeded more rapidly than money wages have increased, thus producing a fall in real wages. Throughout the world this New Dearness has increased political and social unrest. There have been food riots in France, Germany, Austria, and Italy, and similar manifestations have been reported even from a food-exporting country like Argentina. In both the United States of America and Canada the rise in prices has excited great attention and increased popular agitation against trusts and the control of prices. In not a few cities of America attempts have been made by the civic authorities to mitigate higher 
prices by opening markets to relieve their citizens of the burden of the middleman's margin. In Australasia, as elsewhere, there have been official inquiries as to the rise in the cost of living.

Incidentally it may be noted that the New Dearness has struck heavily at the practice of Protection. Protection in modern times has grown contemporaneously with a fall in prices, and the protective duties which were imposed on the Contincnt of Europe and elsewhere were mitigated for the poor by the Free Trade of the engineer. In the latter part of the nineteenth century, as fast as protective statesmen piled on import duties, the engineer, by opening up new lands with his railways and by bringing about a great fall in freights with his steamships, fought Protection inch by inch. Indeed, if we take as an example the price of wheat in Prussia, we find that in the days of German Free Trade, in the decade following the crowning of the Prussian King as German Emperor, wheat fetched about $50 s$. per quarter, whereas in 1895 , when the German wheat duty was $7 s$. $7 \frac{1}{2} d$. per quarter, Prussian wheat fetched only $30 s$. The engineer, in short, had beaten the politician, and the injury which the Prussian eater of bread suffered could only be measured by 
him in 1895 by comparing the Prussian price of wheat, $30 \mathrm{~s}$., with its price of $23 \mathrm{~s}$. in Free Trade England. It will be easily understood how, under these circumstances, food taxes were tolerated on the Continent, when in the experience of living men bread had grown not dearer, but cheaper, under Protection. When the New Dearness came in, however, the position was completely changed. Protective duties were tolerated when they simply meant an addition to a great natural cheapness; they became intolerable when, as in recent years, they meant the addition of artificial to natural scarcity.

The dearness which the world is now suffering is a dearness relative to a point in the history of modern prices which was reached in the middle of the last decade of the nineteenth century. From the high level of the prices of the short-lived trade boom which followed the Franco-German 'war, down to 1896, prices had been continually falling. In terms of human experience, the young people of to-day were nurtured in the experience of cheapness, and even the middle-aged of to-day hardly remember the comparative dearness of commodities in their early childhood. Thus, for the greater part of our population, the present dearness presents itself as a re- 
markable and almost unheard-of phenomenon, and there is little wonder that it excites inquiry and controversy.

Let us see, in as precise terms as it is possible to state the problem, what the variation in prices has been. The economic discussions of recent years have happily familiarised many people with the use of index numbers to measure variations of price. The method is easily understood. 'The prices of a base period, selected as a standard, are represented by 100 , and the prices of other periods are represented as percentages of those of the base year. If this method is applied to a properly chosen list of commodities, the average variation of a representative group of articles can be found. If, further, due regard is paid to the fact that some commodities are more largely used than others, a weighted index number is producedi.e. an index number fairly representing variations in price as they affect ordinary consumption. A weighted index number for wholesale prices has been prepared by the

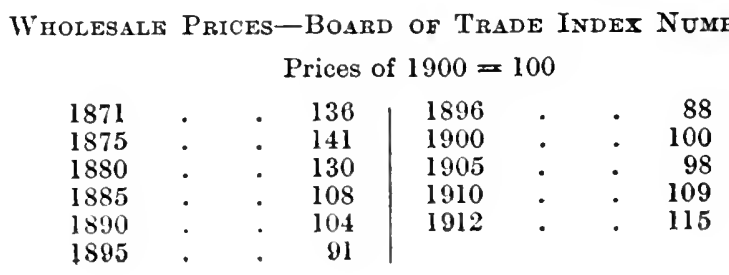


Board of Trade for the years since 1871, and it is given for certain of those years in the table on the preceding page.

This summary record of forty-two years conveys the broad changes clearly to the mind. We see the rapid and continuous descent of prices down to 1896 , followed by a reaction and a return to the price levels of thirty years ago. Cheapness is seen to have been unmade as rapidly as it was made, and now that prices are thirty per cent. higher than in $\mathbf{1 8 9 6 ,}$ and almost at parity with those of the year 1884 (the index number for which is a fraction less than 115), we are constrained to wonder whether there is to be further reaction and a return to the high levels of 1880 or even of 1875.

If we could inform ourselves as to causation in this matter, we should be in a better position to form a fair judgment as to the future of prices. I think that there is material for judgment, if not for confident judgment. Many factors have played their part in the recent history of prices, and it is a matter of no little difficulty to allot to each of them its due weight in producing the results we have experienced. 


\section{§ 2. The Gold Supply and Gold Prices}

By means of money we express the exchange value of all commodities in the terms of a single commodity. Price is simply the ratio of the commodity we select as money to all other commodities at any given moment. The experience of men has led them, in the chief civilisations, to select gold as the recognised standard of value, and the prices we are discussing are the expression of values in terms of gold.

While metallic money played the chief part, or even a major part, in practical exchanges, it is quite evident that variations in the supply of the commodity chosen as standard of value had a considerable and immediate effect upon price. If you settle upon a monetary standard, and decide to express values in terms of it, it is obvious that if the selected standard become more plentiful, prices will rise, since those with commodities to sell will expect a larger quantity of the standard in exchange because of its greater plentifulness. Conversely, an increasing rarity of the commodity selected as standard must lower price, since people will be willing to give more of other commodities in exchange for it, This is the quantity theory of money. 


\section{GOLD SUPPLY AND GOLD PRICES 201}

Can it be invoked to explain the recent price phenomena?

Historically, it is fairly well established that at the end of the sixteenth century, when silver was the general monetary standard, the new flood of silver from Spanish America led to a great rise in prices. Again, there is little doubt that at a later period, when gold had largely supplanted silver throughout the world as a monetary standard, the discovery of gold in California and Australia led to a considerable appreciation of prices in the middle of the nineteenth century. At the opening of the twentieth century there has been again a great increase in the output of gold, and a considerable rise in prices. We need not wonder, therefore, that many have been tempted to seek no further for an explanation. There is little doubt that the quantity theory of money, at least as restated by modern economists, must be reckoned with in this connection, but it will help us to a proper perspective if we set out side by side the variation of prices of the last forty years, and contrast it with the variation of the gold output in the same period. This is done in the following statement.

It will be seen that one thing stands out most clearly in this table, and it is that what- 
Priceg and the Gold OUtput

\begin{tabular}{c|c|c|c|c|c}
\hline Year. & $\begin{array}{c}\text { Board of Trade } \\
\text { Wholesale Prices } \\
\text { Index Numbey } \\
1900=100 .\end{array}$ & $\begin{array}{c}\text { World's Gold } \\
\text { Output. }\end{array}$ & Year. & $\begin{array}{c}\text { Board of Trade } \\
\text { Wholessle Prices } \\
\text { Index Number } \\
1900=100 .\end{array}$ & $\begin{array}{c}\text { World's Gold } \\
\text { Output. }\end{array}$ \\
\hline & 136 & $24,000,000$ & 1895 & 91 & $\mathbf{f}$ \\
1871 & 152 & $20,000,000$ & 1896 & 88 & $42,000,000$ \\
1873 & 152 & $20,000,000$ & 1897 & 90 & $49,000,000$ \\
1875 & 140 & $24,000,000$ & 1899 & 92 & $63,000,000$ \\
1877 & 140 & $23,000,000$ & 1900 & 100 & $52,000,000$ \\
1879 & 125 & $22,000,000$ & 1901 & 97 & $54,000,000$ \\
1881 & 127 & $20,000,000$ & 1903 & 97 & $68,000,000$ \\
1883 & 126 & $23,000,000$ & 1905 & 98 & $79,000,000$ \\
1885 & 107 & $22,000,000$ & 1907 & 106 & $86,000,000$ \\
1887 & 99 & $26,000,000$ & 1909 & 104 & $95,000,000$ \\
1889 & 103 & $27,000,000$ & 1911 & 109 & $96,000,000$ \\
1891 & 107 & $33,000,000$ & 1912 & 115 & $98,000,000$ \\
1893 & 99 & 39 & & & \\
\hline
\end{tabular}

ever the precise effect upon prices of the variation in gold supply may have been, it most certainly has not been the main or dominant factor. From 1871 until 1893 the world's gold output remained an almost stationary factor. Year by year there was a very small addition to the world's stock of gold. We have to think of $£ 20,000,000$ to

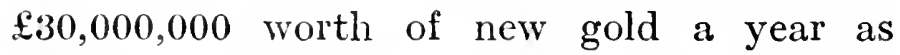
divided up amongst all the world's peoples for every use whatsoever-for personal ornaments, for decorative purposes, for various industries, and for an addition to metallic currencies. During this period of stationary gold output, prices fell rapidly. There followed an increase of gold output, and in 1896 and 1897 , which were record years of low prices 


\section{GOLD SUPPLY AND GOLD PRICES 203}

in modern times, the gold output rose to nearly $£ 50,000,000$ a year. In 1897 , the gold

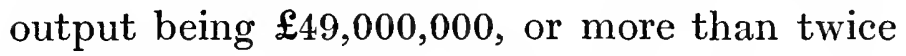
as great as in 1881, prices were nearly onethird less than in 1881. Further, if we continue the comparison down to 1900 , we see that while the production of gold in that year was nearly twice what it was in 1871 or in 1881, prices in 1900 were, as a whole, much lower than they were in 1871 and 1881. That, of course, does not prove that the doubling of the world's gold production did not influence price, but it does conclusively show that there were other forces at work in the world which, whatever the degree of influence of the gold output upon prices may have been, quite overwhelmed that influence, and not only wiped it out, whatever it was, but produced much lower prices in 1900 than in 1871 or in 1881.

After the South African War, which slightly checked output, the advance in gold production was resumed, and in 1912 was half as great again as in 1900. It will be seen that in 1912 the world's gold output reached, in

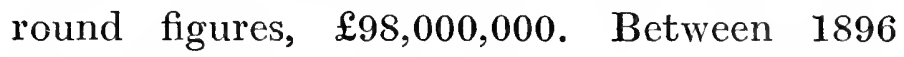
and 1912 prices rose by about one-third; between 1900 and 1912 they rose by about one-sixth. 
Having at least satisfied ourselves that the amount of the gold supply cannot have been the main factor in price causation in the last forty years, we may usefully examine the composition of the Board of Trade index number with a view to ascertaining whether there has been anything like an equal rise in the various important commodities chosen by the Board of 'Trade as representative. The official index number is based upon the wholesale prices of forty-seven principal articles of consumption. Examination shows that of the forty-seven articles, thirty-seven rose and ten fell in the years 1900-1912 (1912 is the last year for which an analysis of the index number is available).

The thirty-seven articles which have risen in price in 1900-12 are as follows: zinc, tin, lead, cotton, British wool, foreign wool, jute, flax, British wheat, foreign wheat, British barley, foreign barley, British oats, foreign oats, maize, hops, rice, potatoes, beef, mutton, bacon, milk, butter, cheese, eggs, sugar, tea, coffee, wine, tobacco, foreign spirits, cotton-seed, linseed, olive oil, palm oil, rubber, and hides.

The ten articles which have fallen in price in 1900-12 are these: coal, pig-iron, copper, silk, fish, cocoa, paraffin, petroleum, bricks, and timber. 


\section{GOLD SUPPLY AND GOLD PRICES 205}

This part of the inquiry is of so much significance, that it is well to show the degree of variation, whether upward or downward, in respect of some of the most important of the commodities mentioned. Here is the record:

Price Variation of Certain Commodities (Prices of 1912 compared with those of 1900)

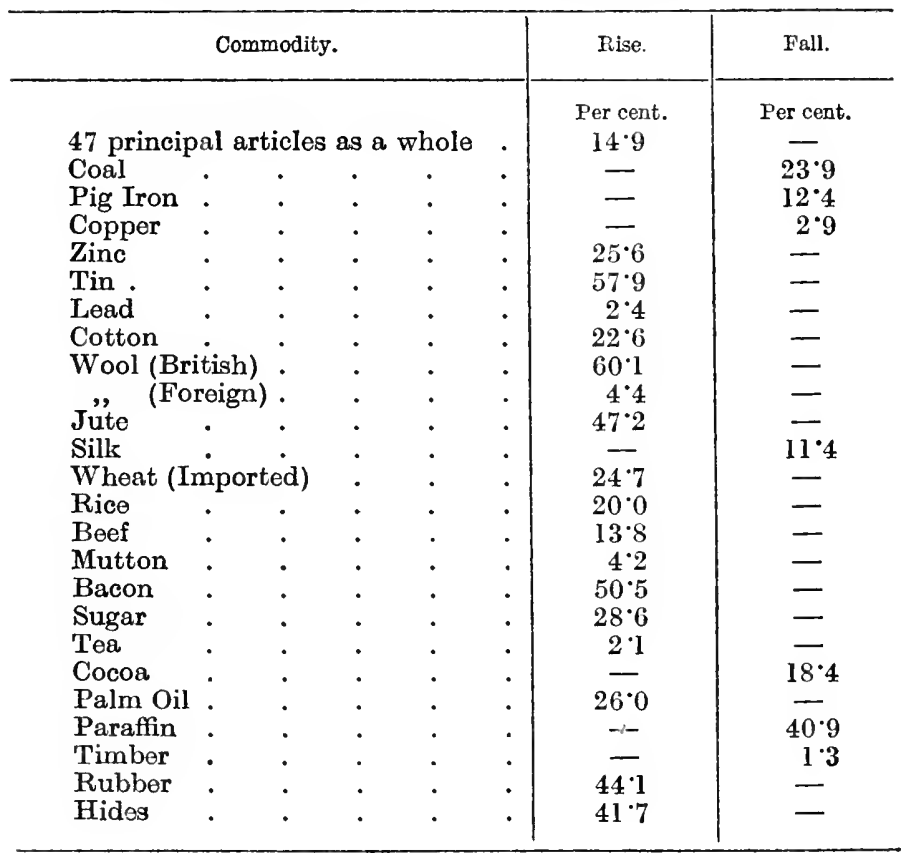

This partial analysis goes far enough to show that there is a very great range of degree of variation, both in the prices that have risen and the prices that have fallen. We see that one important commodity has fallen in price 
by nearly 24 per cent., while another has risen by 60 per cent. Take cognate articles, to get as true a comparison as can be obtained in point of nature. Copper and zinc are metals which are largely used together in industry as an alloy. Copper fell by $2 \cdot 9$ per cent. in 1900-12, while zinc rose by over 25 per cent. We see that lead rose $2 \cdot 4$ per cent., while tin rose 57.9 per cent. Or look at wool, where we have the remarkable fact that foreign wool rose by $4 \cdot 4$ per cent., while British wool rose by 60 per cent.

Foods offer equally remarkable contrasts. Beef rose by 13.8 per cent., mutton rose by only 4.2 per cent., while bacon rose by over 50 per cent.

Let it be borne in mind that all these prices are gold prices-i.e. the exchange value of each of these commodities expressed in terms of gold. As all these prices are gold prices, if the rise in the output of gold had been the main or predominant cause of variations of price in the period, all the articles would have been affected in very much the same way. It is not as though amongst the forty-seven articles there were a few exceptions proving the rule to the contrary. Ten out of these important forty-seven gold prices fell, and the exceptions are too numerous and the variations 


\section{GOLD SUPPLY AND GOLD PRICES 207}

too important to admit of our acceptance of the theory that the great increase in gold production that has followed upon the use of the cyanide process is the main explanation of the rise of the general price index number.

Quite apart from the facts we have examined, I do not think it is very difficult to show that we can hardly expect an increase of gold output in our day to have its old effect upon prices. Our prices are gold prices, but commerce is for the greater part carried on in terms of gold, with for machinery, not gold coins, but credit instruments, which, while theoretically payable in gold, could not at any moment be satisfied by gold if gold were demanded in exchange for them. The use of bills of exchange, and particularly of that form of bill of exchange familiarly termed a cheque, means the coining of commodities into effective money which is unbacked by gold. When a bank gives an overdraft to a creditable customer, it in effect coins credit, and it should be remembered in this connection that the greater part of the enormous so-called "deposits" with British banks consist of such coined credits. They amount at this moment to well over $£ 1,000,000,000$, whereas all the coined gold in the country amounts to not much more than $£ 100,000,000$. 
It is these practical circumstances of the effective currency that we have to consider when we endeavour to form some reasonable estimate of what is the effect upon prices of the introduction of more of the standard metal. We have, in short, to relate the gold supply, in its effect upon gold prices, not alone to the world's stock of gold, but to the world's stock of effective money. We see at once how small is the ratio of new gold, even in actually considerable quantities, to the current credit instruments of our country, to say nothing of all countries.

Even when we compare a year's new gold with existing gold, we must carefully remember that our comparison should be, not with the output of the year before it, or with some other single year at a greater distance removed, but with the world's total stock of gold. A moment's thought will show that year by year the new gold produced has to bear comparison with an ever-increasing total. I suppose that there is now in the world as a whole a stock of something like $£ 3,000,000,000$ worth of produced gold. If, then, the output of 1913 proves to be worth $£ 100,000,000$, the world's stock increased last year by a little over 3 per cent.; we should be unwise to expect any very great influence to be exercised by 


\section{GOLD SUPPLY AND GOLD PRICES 209}

that increase of 3 per cent., even if the world's traders were restricted to metallic exchanges, and credit instruments had never been invented.

Another factor of importance, which profoundly affects the problem, is the velocity of exchange of money. If coined gold or coined credit is turned over quickly, it is the practical equivalent of a much larger quantity of coined gold or coined credit turned over slowly. There can be no question that the velocity of exchange has increased and is increasing, and on this account also we must suppose that the influence of new gold, even in considerable quantity, is a diminishing factor in its effect upon price. The relation of the stock of gold to the volume of trade is also a pertinent consideration, and in this connection the following statement, which compares gold output, British gold imports, and London bankers' clearances, is of much interest.

The first column shows the world's gold output; the second shows how small a proportion of that output is retained in the United Kingdom (the home of the world's only free gold market) for all purposes, whether industrial or personal or decorative or for currency. Compare with the small figures of the second column the facts of the third 
(1) World Gold Output and (2) U.K. Gold Imports Compared with (3) London Bankers' Clearances

\begin{tabular}{|c|c|c|c|}
\hline TEAR. & $\begin{array}{l}\text { WORLD GOLD } \\
\text { OUTPUT. }\end{array}$ & U.K. GOLD IMPORTS. & $\begin{array}{l}\text { LONDON BANKERS' } \\
\text { OLEARANCES. }\end{array}$ \\
\hline & $\mathfrak{f}$ & $£$ & $\mathfrak{f}$ \\
\hline 1895 & $41,000,000$ & $14,600,000$ & $7,593,000,000$ \\
\hline 1896 & $42,000,000$ & -* & $7,575,000,000$ \\
\hline 1897 & $49,000,000$ & $-\dagger$ & $7,491,000,000$ \\
\hline 1898 & $60,000,000$ & $7,100,000$ & $8,097,000,000$ \\
\hline 1899 & $64,000,000$ & $11,000,000$ & $9,150,000,000$ \\
\hline 1900 & $52,000,000$ & $7,800,000$ & $8,960,000,000$ \\
\hline 1901 & $54,000,000$ & $6,700,000$ & $9,561,000,000$ \\
\hline 1902 & $61,000,000$ & $6,200,000$ & $10,029,000,000$ \\
\hline 1903 & $68,000,000$ & $9,900,000$ & $10,120,000,000$ \\
\hline 1904 & $72,000,000$ & 900,000 & $10,564,000,000$ \\
\hline 1905 & $78,000,000$ & $7,800,000$ & $12,288,000,000$ \\
\hline 1906 & $84,000,000$ & $3,400,000$ & $12,711,000,000$ \\
\hline 1907 & $86,000,000$ & $6,200,000$ & $12,730,000,000$ \\
\hline 1908 & $92,000,000$ & - & $12,120,000,000$ \\
\hline 1909 & $95,000,000$ & $7,500,000$ & $13,525,000,000$ \\
\hline 1910 & $96,000,000$ & $6,400,000$ & $14,659,000,000$ \\
\hline 1911 & $97,000,000$ & $8,600,000$ & $14,614,000,000$ \\
\hline 1912 & $98,000,000$ & $6,200,000$ & $15,962,000,000$ \\
\hline
\end{tabular}

- In 1896 we exported on balance $\$ 5,600,000$ of gold.

+ In 1897 imports and exports of gold balanced.

† In 1908 we exported on balance $\mathfrak{k} 3,900,000$ of gold.

column, by which we see that the volume of commercial and financial transactions, represented by cheques and bills cleared at the London Bankers' Clearing House, has increased in the same period from $£ 7,593,000,000$ to $£ 15,962,000,000$.

There are other minor considerations which point the same way. The rapid increase of gold production has been accompanied by a rapid increase of the industrial consumption of gold, and no small part of the new gold has therefore been kept out of currency. It is 


\section{GOLD SUPPLY AND GOLD PRICES 211}

also to be observed that the storing of gold by various nations as "war chests" has absorbed a by no means negligible fraction of recent output.

We may sum up the case as to gold then by saying that, while it is certair that prices expressed in gold must have been affected to some unmeasurable extent by the increased gold output, it is clear that other and by far greater influences must have been also at work.

\section{§ 3. Why Prices Have Risen}

Guarding ourselves carefully against coming to any dogmatic conclusion, I think we may usefully turn to the commercial and industrial history of the world in recent times to gain light upon the causes of the movement of prices. What was the cause of the fall in prices in the eighteen-eighties and eighteennineties shown in the table already given? Broadly, the answer is that it was a period in which the resources of the world were laid under contribution more rapidly than effective demand increased in the white civilisations. We should not use the just word if we said 
that the world's resources were rapidly harvested, for harvest implies a precedent seedtime. It would more nearly express the truth to say that the best resources of the world were rapidly exploited as though they were unlimited in quantity, without regard to the fact that men were reaping where they had not sown, and without regard to the future. The large-scale scratch-farming, the creaming of the world's richest mines, the hewing of the world's best timber, were assisted by the invention of a host of labour-saving appliances. The quickly and cheaply gathered wealth was distributed to the world's markets with the aid of improved ships, the freight charges of which tumbled down in such fashion that whereas in the eighteen-seventies it cost $\gamma d$. or $8 d$. to take a bushel of wheat from New York to Liverpool, it came to cost no more than $1 \frac{1}{4} d$. a bushel.

For a short period in modern times this new large-scale world exploitation proceeded more rapidly than increase of population, or the effective demand exercised by increased population, but the continuous cheapening of products by the opening up of new lands could not proceed far without a check. The use of machinery and the extended use of capital in large units raised the standard of living 


\section{WHY PRICES HAVE RISEN}

of a considerable proportion of the world's white peoples. Emigration took place on a large scale from poor ancient lands with small natural resources to rich new lands of promise. It is hardly realised upon what an enormous scale the transplantation of white men on the globe has been proceeding. Millions upon millions have left countries in which they consumed the cheaper cereals, scarcely any meat, and very little of leather, or metals, or other commodities, to establish themselves in new countries with high standards of living, where they made a new and enlarged draft upon the world's wealth. Thus, what between natural increase of population, a rising standard of life all over the world, and a great emigration from low-wage to high-wage countries, the time soon came when world exploitation, although rapid and continuous, ceased to keep pace with the world's demands for many important commodities. That is the explanation which seems to me to cover the greater part of the ground. It is an explanation which, if traced in detail in connection with each and every commodity named above, will, I think, be found to have a reasonable relation to the facts of the case. If it is the true explanation, as I am inclined to think it is, it is consistent with the rise in price of many articles in which 
supply could not keep pace with the demand, and the fall in price of other articles where supply, owing to the nature of the commodity and the circumstances of its production, was equal, or more than equal, to the occasion.

What of the future of prices? I think we may rely upon scientific endeavour to be equal in the long run to the production of an enduring cheapness. The weapons of science have not yet bcen taken up in earnest by the nations of men. It is no more than haphazard and careless effort which has been applied to the world's resources. Men in a hurry to get rich have despoiled territories and wasted natural wealth in so far as the law of the conservation of matter has permitted them to waste. There can be no reasonable doubt whatever, that the production of organic commodities, whether foods or materials, will be so greatly magnified by scientific method, that the men of the future will produce ample supplies of all necessary things of this kind with little labour. As to inorganic supplies, we may have faith that science will also show a way to the practical utilization of low grades of ore which cannot now be commercially employed. The economic employment and perhaps the colonisation of tropical lands may, it is quite probable, add enor- 


\section{WHY PRICES HAVE RISEN 215}

mously to the world's supply of consumable goods. As to manufactured commodities based upon either organic or inorganic materials, the road to cheapness is already quite plain, given the material supplies. Thus, whatever the course of prices in the near future, the end is not uncertain. The New Dearness will pass, and be succeeded sooner or later by an enduring cheapness-by a scientific plentifulness which may or may not be expressed in terms of gold. 


\section{$\mathrm{X}$ \\ THE ROAD TO RUIN}

\section{$\S 1$. Notes on the Rake's Progress}

THE close of the year 1913 was marked, amongst other things, by a remarkable and concerted outburst by many notable persons on the subject of national expenditure. Attracted by a big black heading, "Down the Steep Path," in an evening newspaper, I found the title of a gloomy column more or less justified by a lengthy jeremiad of an ex-Prime Minister, in which, after stating British public expenditure at $£ 400,000,000$ (which is about $£ 130,000,000$ too high), he went on to say that the great nations were making for "hopeless bankruptcy," and that it was the duty of our commercial community to check our "ruinous and wasteful expenditure." A great and successful shopkeeper, maugre his dividends, has confided to the public that "our too-rapidly increasing 


\section{THE RAKE'S PROGRESS}

national expenditure is steadily weakening our national resources, and sapping our industrial development." A Professor has written to a contemporary and attributed the rise in prices to armaments! As for the leader-writers, they did their best to make an unhappy Christmas, and I know by my extensive correspondence that they worried many innocent people. One of them in a leading daily paper drew for us recently such a picture of rapidly approaching world-wide bankruptcy and disaster that if only one-tenth of it were true the world is past salvation and rushing upon its doom. "Unless this prodigality is checked," wrote he, " nothing can avert a cataclysm that may submerge civilisation. We utterly despair of that check coming from statesmen, whether at home or abroad. Alas! there is no longer a Gladstone." I could match these words from the recent writings of other despairing publicists, but there is no reader of these lines who can fail to have escaped the attention of some of our many Jeremiahs.

Fortunately for our peace of mind our newspapers have not only leader-writers, but reporters. The reporters were sent out to gather material for seasonable Christmas articles, and of these, as of the prophecies of 
unmitigated woe, I made a choice collection for present and future reference. Here are a few of them :

Headlines from the Daily Mail of December 20, 1913 :

\section{THE RICHEST CHRISTMAS.}

GOLDEN HOURS IN THE WEST END. 20,000 SALES A DAY IN ONE SHOP.

Headlines from the Daily Chronicle, December 23, 1913 :

SHOPKEEPERS' HARVEST.

RECORD CHRISTMAS SALE OF PRESENTS.

COMING RUN ON THE POULTRY MARKETS.

Headlines from the Pall Mall Gazette, December 20, 1913 :

A CHRISTMAS OF GOLD. RECORD SHOPPING WEEK IN LONDON. LAVISH PRESENTS. SPENT. 
Which are right, the manufacturers of opinion or the investigators of fact? Have the leader-writers special sources of information above the reach of ordinary reporters ? Have the reporters conspired to misstate the facts as to current prosperity?

For my own part I do not think the reporters in any way exaggerated the Christmas spending of 1913. Common observation makes exceedingly plausible their concerted opinion, uttered after professional talks with storekeepers and shopkeepers, that never before in this country was so much buying done at the close of the year which, according to the prophets of woe, saw our feet set upon the Road to Ruin.

\section{Trade Union Unemployment}

At the end of the month of December, 1888-1913

\begin{tabular}{c|c|c|c}
\hline Year. & Unemployed. & Year. & Unemployed. \\
\cline { 2 - 3 } 1888 & Per cent. & & Per cent. \\
1889 & $3 \cdot 3$ & 1901 & $4 \cdot 6$ \\
1890 & $1 \cdot 7$ & 1902 & $5 \cdot 5$ \\
1891 & $3 \cdot 0$ & 1903 & $6 \cdot 7$ \\
1892 & $4 \cdot 4$ & 1904 & $7 \cdot 6$ \\
1893 & $10 \cdot 2$ & 1905 & $4 \cdot 9$ \\
1894 & $7 \cdot 9$ & 1906 & $4 \cdot 9$ \\
1895 & $7 \cdot 7$ & 1907 & $5 \cdot 6$ \\
1896 & $4 \cdot 8$ & 1908 & $9 \cdot 1$ \\
1897 & $3 \cdot 2$ & 1909 & $6 \cdot 6$ \\
1898 & $5 \cdot 3$ & 1910 & $5 \cdot 0$ \\
1899 & $2 \cdot 9$ & 1911 & $3 \cdot 1$ \\
1900 & $2 \cdot 5$ & 1912 & $2 \cdot 3$ \\
& $4 \cdot 0$ & 1913 & $2 \cdot 6$ \\
\hline
\end{tabular}


But let us call in some more evidence. I turn to the Labour Gazette for January, 1914. I find it there officially stated that at the end of December, 1913, trade unions, with a membership of nearly 1,000,000 men, had no more than $2 \cdot 6$ per cent. of their members out of work, which is a very low rate for the winter season, as will be gathered from the pregnant record on page 219.

It will be seen that in twenty-six consecutive Decembers there have been only five in which the trade union employment rate has stood at less than 3 per cent., and that two of those Decembers are the last two. If $\mathbf{I}$ carried this unemployment record back to the dreadful eighteen-eighties and the awful eighteen-seventies, I could show that, happily, in these modern spendthrift days, workmen do not come upon the degrees of distress through unemployment which occurred while this nation starved its Government as the first prineiple of statesmanship.

Let us next turn to the official record of the Inland Revenue Commissioners, and in particular to the figures relating to gross assessments to income-tax. The following cheerful facts emerge (I add near estimates for the last two financial years). In twenty years the increase has been 


\section{'THE RAKE'S PROGRESS}

Gross Assessments to Income-Tax

(I.e., Incomes of persons having more than $£ 160$ a year; perhaps $1,150,000$ to $1,200,000$ persons in 1914)

\begin{tabular}{|c|c|c|c|c|c|}
\hline & & $£$ & & & $£$ \\
\hline $1894-5$ & . & . $\quad 657,000,000$ & $1907-8$ & • & $980,000,000$ \\
\hline $1895-6$ & . & - $\quad 678,000,000$ & $1908-9$ & . & $1,010,000,000$ \\
\hline $1896-7$ & . & . $705,000,000$ & $1909-10$ & . & $1,011,000,000$ \\
\hline $1897-8$ & . & . $734,000,000$ & $1910-11$ & . & $1,046,000,000$ \\
\hline 1898-9 & - & . $\quad 763,000,000$ & $1911-12$ & . & $1,070,000,000$ \\
\hline $1899-190$ & & . $\quad 792,000,000$ & $1912-13$ & . & $1,100,000,000$ \\
\hline $1900-1$ & . & - $833,000,000$ & $1913-14$ & . & $1,150,000,000$ \\
\hline $1901-2$ & - & . $\quad 867,000,000$ & $1914-15$ & . & $1,180,000,000$ \\
\hline $1902-3$ & - & - $\quad 880,000,000$ & \multirow{2}{*}{\multicolumn{2}{|c|}{ Inc. in 20 years }} & \\
\hline $1903-4$ & • & . $\quad 903,000,000$ & & & $£ 523,000,000$ \\
\hline $1904-5$ & - & - $\quad 912,000,000$ & \multirow{2}{*}{\multicolumn{2}{|c|}{ Inc. in 10 years }} & \\
\hline $1905-6$ & - & - $\quad 925,000,000$ & & & $£ 268,000,000$ \\
\hline $1906-7$ & . & . $944,000,000$ & & & \\
\hline
\end{tabular}

$£ 523,000,000$; in ten years it has been $£ 268,000,000$.

Our entire public expenditure-Imperial expenditure ( $\$ 183,000,000$ without the Post Office outgo, all of which, and more, comes back in revenue), plus local rates, amounts in 1914 to about $£ 273,000,000$. So that in ten years the income of the "classes" has increased by almost as much as our whole public expenditure.

But, lest this evidence be also fallacious, let us turn to the record of external trade. Here is the picture given us, by what are commonly called the Board of Trade Returns, of the rake's progress as reflected in the external commerce by which we so largely live: 
British Exports

(Of British Goods Only)

\begin{tabular}{|c|c|c|c|c|c|}
\hline 1895 & . & $\stackrel{£}{£} \quad 226,000,000$ & 1907 & & $\stackrel{\stackrel{f}{f}}{426,000,000}$ \\
\hline $1896^{\circ}$ & . & - $240,000,000$ & 1908 & $\dot{.}$ & $377,000,000$ \\
\hline 1897 & . & . $234,000,000$ & 1909 & . & $378,000,000$ \\
\hline 1898 & . & . $233,000,000$ & 1910 & . & $430,000,000$ \\
\hline 1899 & . & . $264,000,000$ & 1911 & . & $454,000,000$ \\
\hline I 900 & . & . $\quad 291,000,000$ & 1912 & . & $487,000,000$ \\
\hline 1901 & . & . $280,000,000$ & 1913 & . & $525,000,000$ \\
\hline 1902 & • & . $283,000,000$ & \multirow{2}{*}{\multicolumn{2}{|c|}{ Inc. in 18 years }} & \\
\hline $\begin{array}{l}1903 \\
1904\end{array}$ & $\cdot$ & - $291,000,000$ & & & $£ 299,000,000$ \\
\hline $\begin{array}{l}190 \pm \\
1905\end{array}$ & . & $\begin{array}{l}301,000,000 \\
. \quad 330,000,000\end{array}$ & \multirow{2}{*}{\multicolumn{2}{|c|}{ Inc. in 10 years }} & $£ 234,000,000$ \\
\hline 1906 & . & . $376,000,000$ & & & \\
\hline
\end{tabular}

In eighteen years British exports rose by $£ 299,000,000$. In the last ten years, the years in which public expenditure has risen as never before, exports have risen by $£ 234,000,000$. The $£ 525,000,000$ of 1913 would have been deemed incredible as recently as 1900 , when, in what was deemed "good trade," our exports

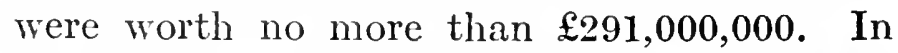
due course the $£ 525,000,000$ of 1913 will appear dwarfed by further developments. We are dealing here with relative terms, and

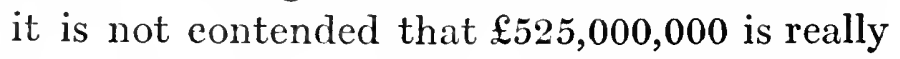
an "enormous" figure; it is merely contended that it is great as compared with $£ 291,000,000$ even when allowance is made for the rise in prices.

These statements may well be rounded with the statistics of bankers' clearances. The Lon- 
don Bankers' Clearing House in 1895 cleared

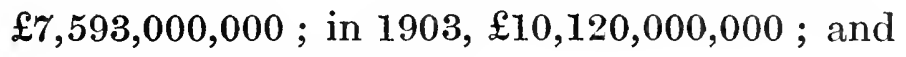
in $1913, £ 16,436,000,000$.

At the close of 1913 some evidences appeared that we were reaching the end of the great and unprecedented trade-boom. The alarmists immediately seized on the fact, and explained it as caused by "armaments." Could folly further go? In the past, when the Navy cost much less than now, trade booms were followed by slumps of the severest character. In the eighteen-seventies and eighteen-eighties the distress was terrible. On the other hand, the present boom, like the previous one, is ending in calm, and, as compared with the old days, little disturbance or distress. The facts, in short, are entirely against the scare-mongers.

It is impossible to resist this mass of evidence. It stands out as beyond the pale of controversy that during the period in which the national expenditure of this country has undoubtedly increased at a greater rate than ever before, our trade and our national income have also increased in an unparalleled degree. If in the year 1903, at the opening of the fiscal campaign, a commercial writer had been bold enough to predict that in 1913 the exports of this country would be worth $£ 525,000,000$, he would have been greeted with derision. 
Let us next see what has happened in regard to national expenditure. The following statement shows the increase in ten years, the periods compared being the financial years ending March 31, 1905, and March 31, 1915, the figures for the latter year being necessarily the estimates of expenditure taken from Mr. Lloyd George's last Budget:

Increase of National Expenditure in Ten Years

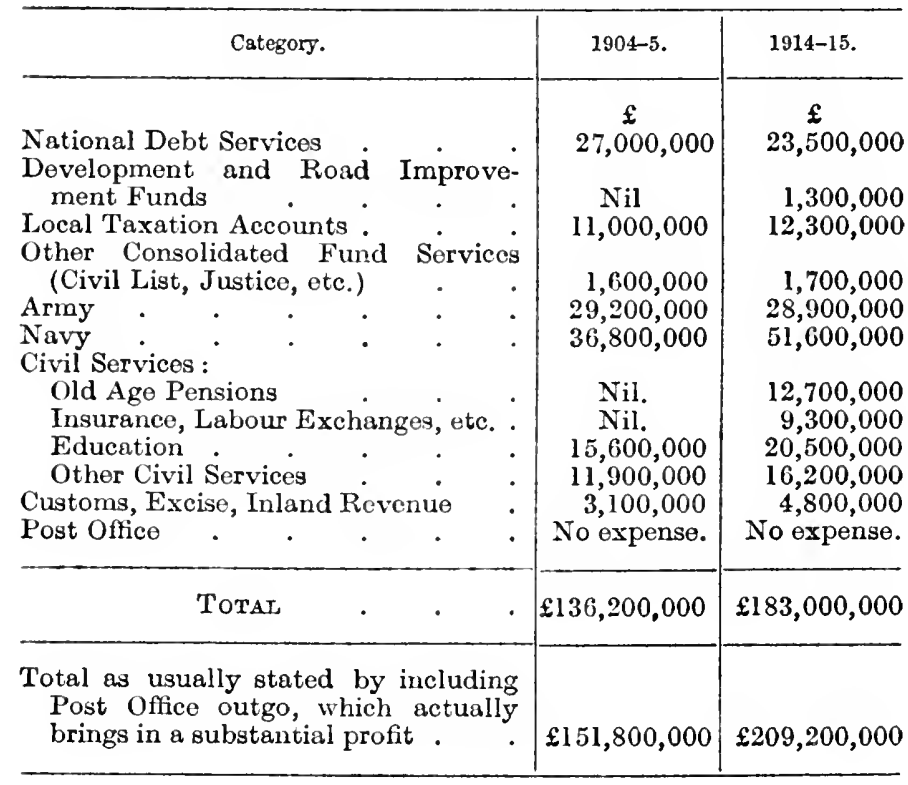

In ordinary statements of national expenditure the Post Office outgo is usually included, but not only does the whole of the Post Office outgo come back to the Post Office, but more 


\section{THE RAKE'S PROGRESS}

beside. In 1904-5 the Post Office made a profit of $£ 4,300,000$. In $1914-15$ it is estimated to make a profit of $£ 5,600,000$. It is misleading, therefore, to include in a statement of national expenditure the always growing outgo of the Post Office, when that outgo is not expenditure by the nation at all, but an exhibition of the growth of the wealth of the country.

In 1904-5 the Post Office outgo was

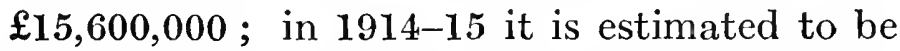
$£ 26,200,000$, an increase of $£ 10,600,000$. If we include the Post Office outgo, we get the figures shown in the last line of the above table, and the national expenditure is untruly shown to be in 1904-5 $£ 151,800,000$ and in 1914-15 $£ 209,200,000$. The national expenditure for 1914-15, as properly stated without the Post Office outgo, is seen to be a very different figure-viz. $£ 183,000,000$.

It will be seen that between 1904-5 and 1914-15 there was an increase of $£ 46,800,000$ in the national expenditure. Iet us compare this with the growth of the income of the "classes" as measured by the gross assessments upon those who have incomes of over $\mathfrak{1 6 0}$ a year (see next page).

It will be seen that the increase in national expenditure has little morc than kcpt pace 
Growth of National Expenditdre compared with Growth OF TAXED INCOMES

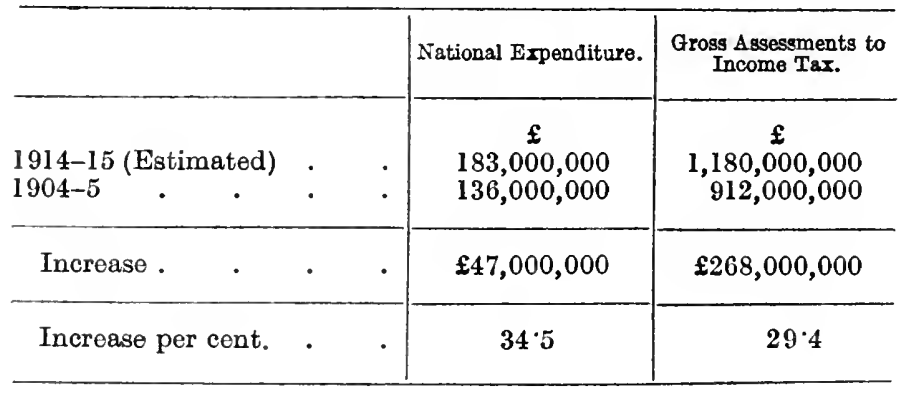

with the growth of class income. Every man of observation must know that without reference to official statistics, for never before in the world's history has luxurious expenditure reached such heights of extravagance. In ten years, while national expenditure has increased by $£ 47,000,000$, the gross assessments to Income Tax have increased by $£ 268,000,000$. And to say that the national expenditure has increased by $\mathfrak{4} 47,000,000$ in ten years is to exaggcrate the facts of the case, for several factors of importance have to be taken into account which considerably modify the increase. In 1904-5 the Unionist Government borrowed $\mathfrak{E} 7,000,000$ for naval and military works, whereas in 1914-15 all such works are placed on the estimates. Again since 1904-5 prices have risen so greatly that fully $£ 10,000,000$ of cxpenditure in 1914-15 is 


\section{THE RAKE'S PROGRESS}

accounted for by this factor. The true increase of expenditure since 1904-5 is thus no more than $£ 30,000,000$, or $£ 3,000,000$ a year, whereas class incomes have increased by $£ 26,800,000$ a year in the same period.

The real lesson to be derived from these figures is the very reverse of that which is commonly preached to us, and in saying so, I am merely repeating what $I$ said again and again in 1904 and in 1905. It was true in 1905 that we were not spending enough upon national purposes; it is only a little less true in 1914. To-day, in spite of what is called public extravagance, we are not yet collecting for national purposes that national tithe which the late Sir Robert Giffen said we might well devote to public needs. At this point I am not discussing what the money is being spent on. I am urging that it is sheer nonsense to say that we cannot afford the figure which our expenditure has reached.

It was in deference to exaggerated statements as to our national expendicure that we put off for so long the granting of Old Age Pensions. If we refresh our minds as to what was said on that subject during the long years when Committees and Commissions were appointed to inquire into the subject, we find that again and again it was stated that we 
could not afford the pensions. In the first edition of Riches and Poverty, published in 1905-in the currency that is of the first financial year treated in the above statement -I wrote :

"With the gross assessments to Income Tax at 900 millions, the expenditure of $\mathbf{1 5}$ millions on a small provision for the aged strikes one not as extravagant, but as an exceedingly modest proposal to mitigate the evils of the Error of Distribution."

And in 1914, writing nine years later, I can paraphrase my former statement by remarking :

"With the gross assessments to Income Tax at 1,180 millions, a further expenditure of, say, 10 millions on Education, and of, say, 20 millions more to establish a Housing Budget for the decent housing of our population, strikes one not as extravagant, but as exceedingly modest proposals to mitigate the evils of the Error of Distribution."

And let us not forget that other nations have also made great increases in their national expenditures in late years. Like ourselves, they were all said to be rushing down the steep path ten years ago, when we were assured in article and pamphlet that " imminent peril" 


\section{THE RAKE'S PROGRESS}

was upon us. Alas for prophecy! There is no single example of a nation which has obeyed the prophets.

It is exceedingly difficult to compare the available figures relating to the national expenditure of the various countries. Accounts are made up in very different ways by different nations, and the character of the expenditure is often as different as the method of accountancy. This should be clearly borne in mind in looking at the following figures, which show the increase of expenditure in nine years by six countries. I have taken the years 1902-11 for each country as the latest for which I am able to compare them all.

Growth of Expenditure of Various Countries in Nine Years

\begin{tabular}{|c|c|c|c|c|c|}
\hline & & & 1902. & 1911. & Increase. \\
\hline & & & $\mathfrak{f}$ & $\mathfrak{f}$ & $\mathfrak{E}$ \\
\hline \multicolumn{3}{|c|}{ United Kingdom (1904-5 } & & & \\
\hline to 19 & $14 *)$ & • & $151,800,000$ & $195,600,000$ & $43,800,000$ \\
\hline France & &. & $147,900,000$ & $184,300,000$ & $36,400,000$ \\
\hline German & mpire & . & $116,000,000$ & $143,800,000$ & $27,800,000$ \\
\hline United & ates & . & $123,500,000$ & $200,800,000$ & $77,300,000$ \\
\hline Italy & - & . & $74,300,000$ & $110,100,000$ & $35,800,000$ \\
\hline Russis & - & . & $228,700,000$ & $287,100,000$ & $58,400,000$ \\
\hline
\end{tabular}

- The figares of 1902-1911 would be mialeading, because in 1902 the Boer War abnormally raised expenditure.

In the United Kingdom figures in the above table I have had to include the Post Office outgo, because all the other figures are similarly 
vitiated. With regard to the German facts, it should be understood that the figures quoted relate solely to the German Imperial expenditure, which does not compare with ours, because each State of the Empire makes expenditure which in our accounts ranks as Imperial expenditure. It is for that reason that the German figures appear to be smaller than ours.

The table then is useless for the purposes of precise comparison. It is useful, however, as showing us that all these six countries have made great increases in their expenditures, and that it is far from true that the United Kingdom has conspicuously increased hers. It is remarkable also that in this very period, during which State expenditures all over the world have been rising rapidly, trade, production, and income have also increased. All the prophecies of disaster and ruin have been most amusingly falsified. Never before has the world witnessed such an advance in trade. Never before was luxury so rampant, not only here, but in Germany, in America, in France, and elsewhere. 


\section{A SENSE OF PROPORTION}

\section{$\S$ 2. Towards a Sense of Proportion}

To return to the consideration of our own national expenditure, we see that it is far from true that the main increase in the last decade has been in respect of armaments, as is so commonly alleged and supposed. The chief cause of the increase is found in the new positive policy of social reform. Old Age Pensions, Insurance, and Labour Exchanges account for over $£ 22,000,000$ of the increase.

As to the Army and Navy, what has been the actual increase in recent years of the armaments which we are assured can bring us only one thing, and that disaster ? It appears that even our Jeremiahs are acquainted with the fact that our Army expenditure has not increased in the last ten years (it has fallen, if the rise in prices is taken into account), for I do not observe any deputations to the Prime Minister on account of the Army, although an Army is, of course, not absolutely necessary to our national existence. It is upon the Navy that so much, is being written in 1914 by men who forget that this is an Island which imports one-half of its food and three-fourths of its materials. In the table of expenditure figures given above, the crude totals of Navy expenditure in 1904-5 and 
1914-15 respectively appear as $£ 36,800,000$ and $\mathfrak{E} 51,600,000$, an increase of $\mathfrak{E} 14,800,000$. These figures, as we have said, are misleading. In 1904-5 the Unionists borrowed largely for naval purposes, whereas the Liberal Government, in pursuance of their pledges made when out of office, have paid for naval works out of revenue, and placed them on the Estimates. A true account of total naval expenditure for the years 1904-5 to 1914-15 is as follows :

British Naval Expenditure

\begin{tabular}{|c|c|c|c|c|c|c|}
\hline Year. & $\begin{array}{l}\text { Total Expen- } \\
\text { diture from } \\
\text { Navy Votes } \\
\text { (net). } \\
\text { (1) }\end{array}$ & $\begin{array}{l}\text { Annulty in } \\
\text { Repayment } \\
\text { of Loans } \\
\text { under Naval } \\
\text { Works Acts } \\
\text { (including } \\
\text { interest). } \\
\text { (2) }\end{array}$ & $\begin{array}{c}\text { Total Expen- } \\
\text { diture exclu- } \\
\text { sive of } \\
\text { Annuity. } \\
\text { (Oolumn 2 } \\
\text { deducted from } \\
\begin{array}{c}\text { Column 1.) } \\
(3)\end{array}\end{array}$ & $\begin{array}{c}\text { Expendl- } \\
\text { ture from } \\
\text { Loans } \\
\text { underNaval } \\
\text { Works } \\
\text { Acts. } \\
(4)\end{array}$ & $\begin{array}{l}\text { Appropria- } \\
\text { tions in Aid. }\end{array}$ & $\begin{array}{c}\text { Gross Total } \\
\text { of Naval } \\
\text { Bxpenditure. } \\
\begin{array}{c}\text { (Totals of } \\
\text { Columns } 3,4 \\
\text { and 5.) }\end{array} \\
\text { (6) }\end{array}$ \\
\hline & $f$ & $£$ & $\mathfrak{f}$ & $\mathfrak{f}$ & & $£$ \\
\hline $904-5$ & 3 & 8 & 36 & 3,402 , & 1 & 41 \\
\hline $1905-6$ & 1,841 & 1,0 & 32,130 & $3,313,6$ & 1,7 & 37,15 \\
\hline $1906-7$ & $31,472,087$ & $1,094,309$ & $30,377,778$ & $2,431,201$ & $1,790,562$ & $34,599,541$ \\
\hline $1907-8$ & 51,156 & $1,214,402$ & 754 & $1,083,663$ & 1,6 & 32 , \\
\hline $1908-9$ & 32, & 4,033 & 7,276 & 948,262 & & 33 \\
\hline & & & & - & & \\
\hline 1 & & 1, & 39 & - & 2, & \\
\hline 12 & $42-5 x-2$ & 1,3 & & _- & & \\
\hline 19 & $44,933,169$ & $1,322,752$ & $43,610,417$ & $\ldots$ & $1,863,892$ & $45,474,309$ \\
\hline 19 & $48,809,300$ & $1,311,558$ & $47,497,742$ & 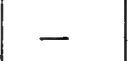 & $2,023,894$ & $49,521,636$ \\
\hline $\begin{array}{l}1914-15 \\
\text { (estimated) }\end{array}$ & $51,600,000$ & $1,311,558$ & $50,338,442$ & - & $2,000,000$ & $52,338,442$ \\
\hline
\end{tabular}

Since 1904-5 our naval expenditure has

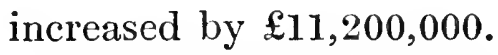

'These figures, however, in their turn are 


\section{A SENSE OF PROPORTION}

vitiated by the fact, always overlooked by those who talk of the recent rise in naval expenditure, that prices have risen very greatly since 1904-5, while the pay of our sailors has been increased by the present Government.

Let us take the increase in naval expenditure since 1904-5 and correct it for the rise in prices and pay. The following statement approximately represents the facts of the case :

InCRease in Naval Expenditure since 1904-5

\begin{tabular}{|c|c|c|c|}
\hline Year. & & Gross Naval Expenditure. & $\begin{array}{l}\text { The Same Corrected for } \\
\text { Rise in Prices and Pay. }\end{array}$ \\
\hline \multirow[t]{3}{*}{$\begin{array}{l}1904-5 \\
1914-15\end{array}$} & $\cdot$ & $\begin{array}{c}\mathfrak{E} \\
41,100,000 \\
52,300,000\end{array}$ & $\begin{array}{c}\mathfrak{E} \\
41,100,000 \\
47,300,000^{*}\end{array}$ \\
\hline & & $£ 11,200,000$ & $£ 6,200,000$ \\
\hline & & Apparent increase. & True increase. \\
\hline
\end{tabular}

- This figure means that if prices and pay had remalned at the level of 1904, the naval

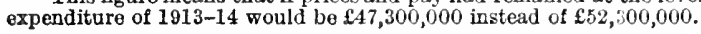

Neglecting prices and pay, naval expenditure in 1904-5 to 1914-15 has increased by $£ 11,200,000$. Taking these important items into account, it has increased by no more than $£ 6,200,000$.

It matters very little, however, whether the $\mathfrak{f} 6,200,000$ or the $\mathfrak{1 1}, 200,000$ be taken into comparison, or whether, in order to get the most alarmist view of the situation, we unjustly compare 1914-15 with 190\%-8, and, 
most unreasonably neglecting the rise in prices and pay, put it that our gross naval expenditure in the last seven years has risen by

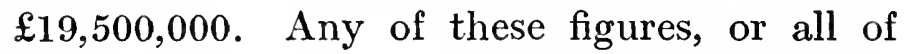
them, ought to be considered in relation to the resources of the nation, and when that is done, any of them or all of them appear what they are-insignificant fractions of the national income.

That is not to justify one penny of the increase, or, for that matter, to justify one

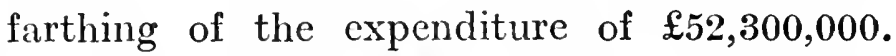
If we do not want a Navy, then not a fraction of the whole, but the whole, is waste. If we do want a Navy, on the other hand, it is childish to say that we cannot afford it, or that the maintenance of it brings us anywhere near to ruin or disaster. This country can as easily afford a $£ 50,000,000$ Navy as a middleclass man can afford to buy what is now irreverently called a push-bicycle.

Argument that we do not want a Navy, or that the Navy is much too large, or a little too large, may or may not hold water. What is absolutcly clear is that if we want it, we can afford it.

It is not my purpose here either to argue for or against a Navy, or for or against any particular degree of naval defence whatsoever. 


\section{A SENSE OF PROPORTION 235}

I confine myself solely to the point: Is the present cost of our defences beyond our means? The main argument used against the Navy Estimates is that they are bringing us to ruin, and my contention here is that such a suggestion is without reasonable foundation.

It is the fact that Britain spends more on new motor-cars than on new battleships. It is the fact that, according to the estimate of The Times' motor expert, the purchase and maintenance in this country of motor pleasure vehicles cost $\mathfrak{E 7 5 , 0 0 0 , 0 0 0}$ a year. (It may be observed that whereas in the last ten years the Navy has only cost the few gallant lives lost in submarines, etc., motor vehicles have slain thousands and maimed tens of thousands ; but let that pass here, although $\mathbb{I}$ am astonished that it passes so easily with those who oppose our defences on the score of humanity.)

It is the fact that we spend on non-intoxicating beverages far more than the entire cost of the Army and Navy.

It is the fact that we spend on intoxicants more than twice the cost of the Army and Navy.

It is the fact that the rich spend on luxuries (which create highly variable trades) many times the cost of the Army and Navy.

It is the fact that in 1913 the British invest- 
ing classes made an unparalleled investment in publicly issued securities, amounting roundly to $£ 250,000,000$, and that-oh! most monstrous disproportion!-- $£ 200,000,000$ of this capital was invested abroad, lured by 6 per cent., while at home housing, canals, railways, afforestation, municipalities, and, above all, a national electrical power system, lacked the capital they needed. In one year the British investor could clear up the worst of the housing problem; in a second year he could give the nation a scientific power supply which would recreate social and industrial life and multiply our wealth production again and again.

'Two or more blacks do not make a white, and none of these facts defends the Naval Estimates. Each of these facts, however, makes mineemeat of the argument that we camnot afford the Navy, and that its trifling increase in recent years brings us to the edge of a financial abyss. Each of them equally disposes of the mischievous notion that we cannot afford social reforms because of the cost of the Navy.

The fact is that it is only too easy to forget the scale upon which the affairs of a great nation must be now conducted. Not long ago I heard it stated in the House of Commons, in a specch of considerable eloquence, that 


\section{A SENSE OF PROPORTION}

with a sum of money which need not be precisely stated, but which amounted to a few hundred millions, we could create a Utopia in this country. I fear it is true that a great many people are of this opinion, for commonly

I observe that you have only to mention a million pounds to make people gasp, while to speak of ten or twenty millions leads to complete paralysis of their mental faculties. That is one of the disadvantages of belonging to a big country. If I were to write down that, having four dependents, and thus constituting with them the statistician's delightful average family of five persons, I had spent upon them, it matters not for what purpose, 5s. a head, no one would suspect me of extravagance, even though the $25 \mathrm{~s}$. had been spent upon mere amusement. If, however, I were to write down a proposal that the Government of this country should spend $£ 11,500,000$ more in a year upon a great public purpose, a very large number of worthy people would immediately suffer a great disturbance of mental equilibrium, and ask where such a lot of money was to come from. But the "lot of money" is just $5 s$. per head of our population.

A sense of proportion is a most difficult quality to cultivate, and it is to be feared that 
there are few who possess it. It is the chief difficulty which stands in the path of the reformer, and it is the besetting sin of many of those who desire to be reformers. I am beginning to think that almost the first thing a child ought to be taught at school, as soon as it understands how to perform the process of simple multiplication, is to multiply the number of people in this country by various sums, large and small, so that the budding citizen may grasp the useful truth, never to be unlearned or forgotten, that forty-six times the merest trifle amounts to a big sum. A child so taught would not be likely to grow up into an adult easily dazzled by talk about millions in connection with questions of Government. If he heard a ranting politician endeavouring to startle an audience by telling them that this, that, or the other was costing five, ten, or fifty millions, he would smile, remembering that these sums for our big nation amount to only $2 s .2 d ., 4 s .4 d$., and $£ 11 s .8 d$. per head respectively, and that therefore they are not large sums from a national point of view, but absurdly small ones-sums with which little can be done. And if, fortunately or unfortunately, a child so taught came to be a Member of the House of Commons, he would not suffer from that pettiness of outlook and timidity of 


\section{A SENSE OF PROPORTION}

advance which burkes for the nation so many good and useful things.

If 46,000,000 people are supplied with a starvation diet, barely enough to keep body and soul together, the cost of the supply as a whole looks big, but it is not really big. I suppose you could keep the British people just alive for $2 s$. a week per head spent in food. Let us see what that comes to. It works out at $£ 239,000,000$ per annum. It was a sum of similar magnitude which was recently referred to in a naval debate in the House of Commons as the price of a "Utopia." The speaker had forgotten to relate his few hundred million pounds to the needs of forty-six million people.

Let us trace the evil I refer to in another connection. It is well known, and indeed generally admitted, that the majority of the houses of the United Kingdom are no credit to it. As a consequence of this well-known fact, we have a tremendous outpouring of eloquence, and of rhetoric of a tearful character, upon housing reform." Housing reformers, indeed, are as common as good houses are rare. But when we come to examine nearly every scheme of housing reform, we find small and timorous proposals calculated to make as much impression upon the housing 
problem as though you took a pebble and threw it into the Atlantic Ocean. That is, in effect, what the numerous Acts for the " better housing of the working classes" have accomplished in all these weary years of waiting. Each successive Act has thrown a pebble in the ocean, and as a result to-day our cities are dreary wastes of bricks and mortar, in which good and beautiful houses are hard to find. The simple fact is that the $46,000,000$ people of the United Kingdom require $9,000,000$ good houses to live in, and that if $9,000,000$ houses with the land attached to them cost no more than, on the average, $£ 500$ apiece-and $£ 500$ builds little in the way of a house-the bill for houses comes out at $\mathfrak{f} 4,500,000,000$. A man who once got that into his head would never again allow himself to talk about constructing a "Utopia" with a few hundred millions.

And thus also it is with education. In the United Kingdom the boys and girls over thirteen and not over sixteen years of age number roundly 2,500,000. As things are, the greater number of these are left without systematic training, the great majority of the children of the country leaving school at thirteen years of age. Suppose we decide to educate these 2,500,000 children, and to spend 


\section{A SENSE OF PROPORTION 241}

upon them no more than $£ 6$ per child per annum. The bill would obviously amount to

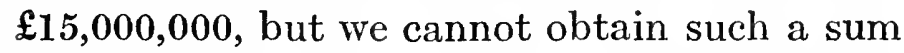
for the purpose because it is not realized that a nation of $46,000,000$ people can very easily find the $6 s .6 d$. per head-for that is all it is-which is necessary to accomplish the fruitful work of training what is now untrained. The general truth which emerges is this: that a great nation needs great policies, that the smallest affairs of a great nation bulk largely in the aggregate, that to make any considerable impression upon the life of a great nation calls for great expenditures, and that it is idle to dream of cheap Utopias.

§ 3. National Expenditure and Economic Stabilit'Y

Further to test the current alarms, let me take an expression used by one of the scared writers I have referred to-viz. the statement that we are being "bled white in order to satisfy the ravenous maw of clamorous militarism." It is well to test this not only by the evidence already given, but by the incidence of 
taxation upon the individual. Let us see how different classes of men are being "bled white." I take some typical cases: (1) a clerk with $£ 200$ a year ; (2) a physician making $£ 700$; (3) a barrister making $£ 1,000$; (4) a manufacturer earning $£ 2,500$; (5) a farmer of 380 acres at a rental of $£ 475$, making $£ 400$; (6) a man living upon investments from which he draws an income of $£ 5,000$. The following table shows what each of these persons has left in income after being "bled white" by Income-tax :

SoMe Typical Income-Tax "Burdens"

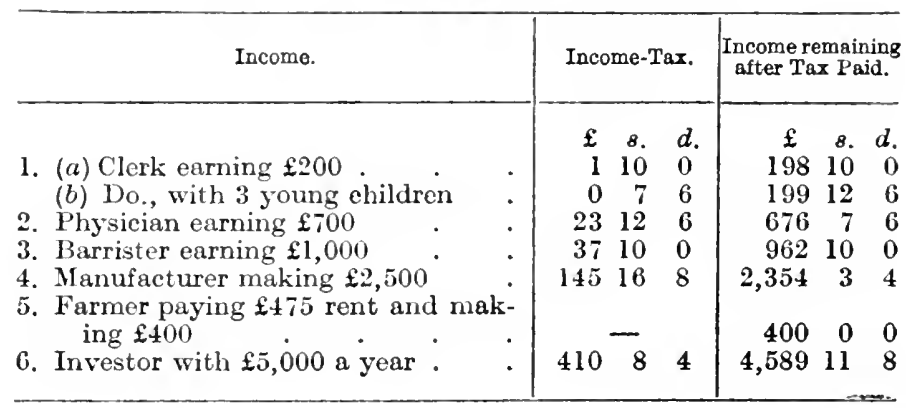

I submit with very great confidence that, in view of these facts, it is ridiculous to say that any one of these persons is overburdened or ruined by taxation. From the farmer who escapes Income-tax altogether to the clerk who has to pay $30 s$., from the $£ 700$-a-year 


\section{EXPENDITURE AND STABILITY 243}

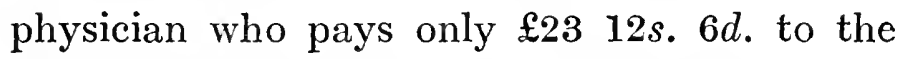
sleeping partner who pays only $£ 410$ a year although he has as much as $£ 5,000$ a year, each individual can only be said, if there is any value attaching to the meaning of words, to be taxed very lightly indeed. Many middle-class men spend more on golf than on the Navy; if, then, the Navy "bleeds them white," how do they pay for their golf ?

We see as clearly from the individual point of view as from the national point of view that those who are threatening us with national bankruptcy simply do not know whereof they speak.

I pass to some observations, partly of a tentative character, upon national expenditure in its relation to trade, production, and employment.

It was the accepted view in days not long removed that Britain was imperilled by every pound that she added to her national expenditure. You will find the expression of this view in countless places, from Hansard to newspaper article, from election speech to alarmist pamphlet, throughout the long period in which we were constructing slums in our cities, neglecting education, making no national provision for the aged poor, and allowing 


\section{THE ROAD TO RUIN}

physical deterioration to become the lot of a considerable proportion of our population. That, in practice, was what "Peace, Retrenchment and Reform" meant to this country. We know that the mere hint of national

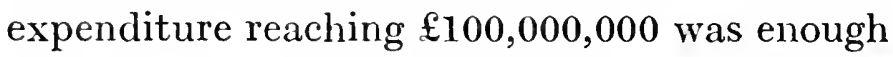
to throw into panic the leading statesmen of the past. We remember that Mr. Gladstone, blind to the fact that Income-tax payers formed then, as now, a small proportion of the electorate, actually went to the country on the cry, amongst other things, of "No Income-tax."

What has also to be recorded of these years during which it was made a chief object of statesmanship to keep poor the Government of a rich country? History tells us that these years of public parsimony were marked at frequent intervals by grave commercial crises, by financial panics, and by degrees of unemployment which have been unknown in recent years. The eighteen-seventies and the eighteen-eighties-decades of the severest national "economy" -were also years which saw millions plunged into the deepest distress.

At long last we are beginning to awaken to a sense of national responsibility in regard to many problems. As a consequence, public 


\section{EXPENDITURE AND STABILITY 245}

social expenditure has been begun and considerably increased in the last ten years (rising from nil to $£ 22,000,000$ a year), while the expenditure on defence has increased by a much smaller sum. If the old tradition had been a true tradition, if the oid conception of starving the Government had been a true conception, what ought to have happened by 1914? There can be only one answer. If there was any virtue in the old ideas of government, these last few years could only have been periods of ruin and disaster for trade and industry, and of unprecedented privation for millions of workmen. Accomplished facts have shown us that the increased public expenditure has been accompanied by increased prosperity. It would, of course, be as futile as the conceptions which I am countering to argue that the record trade, record production, record employment, record profits, record external trade, and record National Dividend of 1913 were consequences of increased national expenditure. It is, however, very seriously suggested to those who talk of ruin while enjoying prosperity that it is for them to explain away if they can the remarkable evidence to which I have referred, and the further evidence that every man with eyes can gather for himsclf in the places 
where the lion's share of the national income is enjoyed and expended.

So far from it being true that taxation has become intolerable, the truth is that it has not touched the fringe of luxury and extravagance. Never before in this country has luxurious expenditure been so wanton. Even while the scared ones have been talking about ruin by armaments, the expenditure on new motor vehicles has risen and passed the expenditure on new warships. Even while we have it preached that the Government is ruining the investing classes, the investing classes are spending upon what Professor Marshall calls things that "do little or nothing towards making life nobler or truly happier," nearly three times as much as the entire Imperial expenditurc of the country.

For my own part, I do not doubt that the increased national expenditure of recent years, which has not been mainly on the Navy, so far from being bad for trade and industry, has been highly beneficial to the productive and commercial powers of the country. I believe that the increased national expenditure has been a subtraction from a too rapidly growing luxurious expenditure-an expenditure which supports trades of a highly fluctuating character which are bad trades from the point of 


\section{EXPENDITURE AND STABILITY 247}

view of commercial stability and the proper employment of those who work. I believe that the subtraction from private waste and the addition to public expenditure has, on the whole, steadied trade, production, and employment. 


\section{XI}

\section{TARIFF REFORM-TEN YEARS AFTER}

§ 1. Mr. Chamberlain's Case and the Accomplished Facts

MORE than ten years have elapsed since Mr. Chamberlain took his first step in the great fiscal agitation which has made so great-and in many respects, so happya change in the orientation of British politics. It is not very profitable to endeavour to imagine what processes of thought brought him to the position which he occupied when at the end of 1903 he formulated concrete proposals for reforming the Customs tariff, but we may well remind ourselves of the case for an alteration in our fiscal system which was then presented.

It amounted to a representation that the Colonial Preference was not only an Imperial good, but a British good. Indeed, the speech at Glasgow on October 6, 1903, laid stress upon the case for Preference as a means of reviving and stimulating British industry and 


\section{MR. CHAMBERLAIN'S CASE 249}

trade. The Preference was not so much a sacrifice as a very good bargain for the British citizen, for the story went that we had only to consent to a tax upon food of small dimensions to ensure at once a consolidation of Empire and a special pull upon British Colonists as customers. Mr. Chamberlain asserted that the export trade of the United Kingdom had been "practically stagnant for thirty years," while other countries had made enormous advances; that the position would have been worse, but for the fact that British Possessions had bought increasingly from us while foreign trade had fallen off; the trade of the Colonies was essential to our future. Therefore we were to say to our great Colonies :

"There are many things which you do not now make; many things for which we have a great capacity of production-leave them to us as you have left them hitherto. Do not increase your tariff walls against us. Pull them down where they are unnecessary to the success of this policy to which you are committed. . . . We offer you a Preference; we rely on your patriotism, your affection, that we shall not be losers thereby."

The suggestion that the Colonies should curb their industrial development, and be content to supply food and material to British 
manufacturers was, of course, unconsciously borrowed from the Mercantile Theory, which postulated, inter alia, that a Colony should be regarded as, and compelled to be, a hewer of wood and drawer of water for the Mother Country. In the unhappy past, penal laws enforced this pernicious doctrine; in 1903 we were to go cap in hand and ask for what in ancient days we demanded. It is not surprising that the Colonists, who made an end of the Colonial expression of Mercantilism, made answer to Mr. Chamberlain in effect that we should do well to mind our own industries.

And what was the price to be paid for the suggested quasi-monopoly of the British manufacturer in Colonial markets ? Let the answer be given in Mr. Chamberlain's words:

"What will it cost you? 'What do the Colonies ask? They ask a preference on their particular products. You cannot give them, at least it would be futile to offer them, a preference on manufactured goods, because at the present time the exported manufacture of the Colonies is entirely insignificant. You cannot, in my opinion, give them a preference on raw material. Therefore, if you wish to have preference, if you desire to gain this increase, if you wish to prevent separation, you must put a tax on food. The murder is out." 


\section{MR. CHAMBERLAIN'S CASE 251}

But it was to be mitigated murder, for Mr. Chamberlain offered the people the remission of other taxation to compensate them for the new food taxation.

The new taxes on food were to be on foreign corn $2 s$. a quarter, except upon maize, "partly because maize is a food of some of the very poorest of the population and partly also because it is a raw material for the farmers," and 5 per cent. on foreign meat and dairy produce, except bacon, because "bacon is a popular food with some of the poorest of the population." Further, there was to be a substantial preference "upon Colonial wines and perhaps upon Colonial fruits." Against these new taxes Mr. Chamberlain proposed to remit three-fourths of the tea duty (then standing at $6 d$.), half of the sugar duty (then standing at $4 s .2 d$. per cwt.), and some fractions on cocoa and coffee. Mr. Chamberlain put it that even if the British consumer paid the whole of the new duties suggested, the remissions would leave him practically in the same position. The Treasury would lose by the remission of old duties, but it would make up for the loss by "the other branch of this policy of fiscal reform, in that part of it which is sometimes called Retaliation and sometimes Reciprocity." "A moderate duty 
on all manufactured goods," he went on, " not exceeding 10 per cent. on the average," would give the Exchequer at least $£ 9,000,000$ a year and perhaps $£ 15,000,000$ a year.

Following this lead as far as Mr. Balfour would allow them, the Unionists became involved in a policy of food taxation, the incidence of which they have vainly endeavoured to conceal from themselves and others. It should be fairly obvious that if a policy of taxing foreign food and leaving Colonial food free is to amount to a preference at all, it can only be because the British consumer pays the import duty. For if the foreign supplier can afford to lower the price of his supply by the amount of the duty, then obviously the Colonial producer cannot benefit, unless in the unprofitable satisfaction of knowing that the foreign producer is robbcd of part of his aforetime profit. The very fact that such an arrangement is claimed to be a Preference for the Colonies means, and can only mean, that the British consumer pays an increased price for the entire wheat supply, and that in so far, thercfore, as the Colonist contributes to the supply, he gets the higher price. The present writer was able to show within forty-eight hours of the delivery of Mr. Chamberlain's speech approximately what the suggestion 


\section{MR. CHAMBERLAIN'S CASE}

meant, taking the facts of 1902 as a basis. It meant that upon corn, meat, and dairy produce together, the British consumer would pay $£ 16,300,000$ more in higher prices, of which less than $\mathfrak{E} 6,000,000$ represented gain to the British Treasury, the remainder going to the home and Colonial producers of food. The Colonial gain amounted to only $£ 1,600,000$, or about $3 s$. per head of the then existing 11,000,000 whites in the self-governing Colonies.

Indeed, the true incidence of import duties, save in exceptional cases which do not affect the general issue, was sufficiently acknowledged in Mr. Chamberlain's proposals. He was careful to explain that he had no intention of taxing raw materials, and it is, of course, ridiculous to suggest that the economic laws governing the incidence of import duties on raw materials are different from those governing the incidence of similar duties on food stuffs. In case after case, as, for examples, wool and mutton, hides and beef, bristles and pork, a raw material and a food are derived from the same animal, and derived by us necessarily from the same sources, so that if a duty on mutton or beef or pork does not raise price, then most assuredly a duty on wool or hides or bristles cannot raise price, but is merely a delightful expedient for cxtract- 
ing money from the pockets of persons in places abroad. And then there were Mr. Chamberlain's naïve admissions with regard to maize and bacon, which could searcely escape the attention of the most careless observer.

As for the need for Preference from the Colonial point of vicw, it was clear enough in 1903 that the self-governing Colonies stood in little need of it, but the recorded facts of the years that have elapsed have deprived the Protectionists of every shred of excuse for the suggestion that we should tax food on behalf of the Colonies. The facts of the case with regard to our imports of corn in the last seventecn years are shown opposite.

Between 1902 and 1912 our supplies of wheat from the Colonies have risen from about $25,000,000$ cwts. to $66,000,000$ cwts. If we go back to 1895 , the turning-point when prices which had for long been falling began again to rise, we see that the forcign supply was then $8+$ per cent. of the whole as against 16 per eent. from British Possessions, whereas in 1912 the foreign supply had fallen to 47 per cent. and the supply from British Possessions had risen to 53 per cent. The change, unfortunately, does not make the food supply of the United Kingdom any safer. On the contrary, 
MR. CHAMBERLAIN'S CASE 255

UNited KingdoM ITheat IMPoRts

\begin{tabular}{l|c|c|c|c}
\hline & \multicolumn{2}{|c|}{ From Foreign Countries. } & \multicolumn{2}{|c}{ From British Possesslons. } \\
\cline { 2 - 5 } Year. & Mill. cwts. & $\begin{array}{c}\text { Per cent. ot } \\
\text { Total Imports. }\end{array}$ & Mill. Cwts. & $\begin{array}{c}\text { Per cent. of } \\
\text { Total Imports. }\end{array}$ \\
\cline { 2 - 4 } 1895 & 90 & 84 & 17 & 16 \\
$1896^{*}$ & 91 & 92 & 8 & 8 \\
$1897^{*}$ & 81 & 91 & 8 & 9 \\
1898 & 77 & 82 & 18 & 18 \\
1899 & 78 & 79 & 21 & 21 \\
1900 & 86 & 88 & 12 & 12 \\
1901 & 82 & 81 & 19 & 19 \\
1902 & 82 & 77 & 25 & 23 \\
1903 & 85 & 72 & 32 & 28 \\
$1904 \dagger$ & 73 & 61 & 46 & 39 \\
1905 & 72 & 61 & 43 & 39 \\
1906 & 78 & 69 & 35 & 31 \\
1907 & 74 & 64 & 42 & 36 \\
1908 & 82 & 75 & 27 & 25 \\
1909 & 68 & 60 & 45 & 40 \\
1910 & 66 & 55 & 53 & 45 \\
1911 & 58 & 51 & 54 & 49 \\
1912 & 58 & 47 & 66 & 53 \\
\hline
\end{tabular}

- Great Australian Drought.

t Observe that since 1904 the figures refer to " countries of consignment" instead of " countries of shipment" as in previous years; hence from 1904 onwards the statistics more accurately represent the true origins of the wheat.

to derive food from the Colonies rather than from foreign countries is, in time of war, to make it less rather than more safe. In so far as the claims of Preference to stimulate the Colonial food supply are concerned, however, they become ludicrous in view of the accomplished facts.

On the side of foreign competition and British trade progress Mr. Chamberlain's case has been no more fortunate. It did not need further experience to tell us that the picture of stagnation was based upon a misconception 
of the facts, and Mr. Chamberlain's comparison of the artificially inflated trade figures of $\mathbf{1 8 7 2}$ with the artificially depressed statistics of 1902 was exposed by the present writer as soon as it was coined by Mr. Chamberlain or rather by those who prepared his brief. Mr. Chamberlain did not content himself with pointing to a supposed stagnation in British trade as a whole. In speech after speech he referred to specific trades, and selected certain of them as illustrations. At Greenock on October 7, 1903, he said :

"Agriculture, as the greatest of all trades and industries of this country, has been practically destroyed. Sugar has gone; silk has gone; iron is threatened; wool is threatened; cotton will go. How long are you going to stand it? At the present moment these industries, and the working men who depend on them, are like sheep in a field."

In similar vein on October 28, 1903, he asked at Liverpool, "What about glass?" And at Bristol on November 21, 1905, he remarked, "There is also the case of boots and shoes."

As to the alleged destruction of agriculture, it is plain that Mr. Chamberlain did not know -and as for that matter it appears that there are few who realise-that we produce in this country more than one-half of the food 


\section{MR. CHAMBERLAIN'S CASE 257}

we eat, of kinds, that is, that can be grown in this country. As to the industries mentioned that have exports, I give in the following table an account of the external trade in each of them for the years 1900 and 1913 (I go back to 1900 because that was a year of record trade) :

External Commerce in Certain British Industries

\begin{tabular}{|c|c|c|c|c|c|c|c|c|}
\hline & & & & & $\begin{array}{r}\text { I } \\
\text { (For } \\
\text { su }\end{array}$ & $\begin{array}{l}\text { ports } \\
\text { ome Con- } \\
\text { ption). }\end{array}$ & (Britisl & $\begin{array}{l}\text { ports } \\
\text { Croods only). }\end{array}$ \\
\hline & & & & rear. & & Rise or Fall. & & Rise or Fall. \\
\hline Iron & . & . & . & $\begin{array}{l}1900 \\
1913\end{array}$ & $\begin{array}{r}6 \cdot 9 \\
14.9\end{array}$ & +8.0 & $\begin{array}{l}31 \cdot 6 \\
54 \cdot 3\end{array}$ & $+22 \cdot 7$ \\
\hline Woolle & & . & . & $\begin{array}{l}1900 \\
1913\end{array}$ & $\begin{array}{r}10 \cdot 7 \\
9 \cdot 2\end{array}$ & -1.5 & $\begin{array}{l}23 \cdot 8 \\
37 \cdot 7\end{array}$ & $+13 \cdot 9$ \\
\hline Cotton & & . & . & $\begin{array}{l}1900 \\
1913\end{array}$ & $\begin{array}{r}4 \cdot 1 \\
10 \cdot 0\end{array}$ & +5.9 & $\begin{array}{r}69 \cdot 7 \\
127 \cdot 2\end{array}$ & $+57 \cdot 5$ \\
\hline Silks & . & . & . & $\begin{array}{l}1900 \\
1913\end{array}$ & $\begin{array}{l}14 \cdot 0 \\
13 \cdot 3\end{array}$ & -0.7 & $\begin{array}{l}2 \cdot 1 \\
2 \cdot 2\end{array}$ & +0.1 \\
\hline Glass & . & . & . & $\begin{array}{l}1900 \\
1913\end{array}$ & $\begin{array}{l}3 \cdot 1 \\
3 \cdot 3\end{array}$ & +0.2 & $\begin{array}{l}1 \cdot 0 \\
1 \cdot 8\end{array}$ & +0.8 \\
\hline Boots & . & . & . & $\begin{array}{l}1900 \\
1913\end{array}$ & $\begin{array}{l}0 \cdot 6 \\
1 \cdot 0\end{array}$ & +0.4 & $\begin{array}{l}1 \cdot 5 \\
4 \cdot 2\end{array}$ & +2.7 \\
\hline All Ma & auf & ures & . & $\begin{array}{l}1900 \\
1913\end{array}$ & $\begin{array}{l}110.1 \\
164.1\end{array}$ & +54.0 & $\begin{array}{l}228 \cdot 3 \\
411 \cdot 6\end{array}$ & +183.3 \\
\hline
\end{tabular}

In spite of " threatenings," the iron and steel trade has increased its exports in thirteen years by $£ 22,700,000$, and in the same period the imports have increased by $£ 8,000,000$. These 
figures indicate what is the truth-viz. that the British iron and steel industry, while stronger than ever before, is the subject of fierce competition. As compared with the iron industry of either Germany or America, it has continued to lose ground. The loss of supremacy to America is so far from surprising, that it was prophesied with certainty by qualified observers fifty years ago; it is the inevitable consequence of the possession by America of the best coal and iron supplies in the world. The fact that the German iron industry has gained relatively upon ours is certainly far from satisfactory. It has a natural basis in the possession by Germany not only of good coal, but of fine supplies of phosphoric ores, which have in recent years been made available by British invention. When this is said, however, a good deal must be granted to German science and trade organisation, and to the co-operation of the German State railways. Without low freights German ironmasters could not have economically carried their ore to their coal, and it is not too much to say that railway rates at the British level would have prevented the rise of the German iron trade. Herein is cause for serious study and reflection.

As to wool, we see an actual decline in the 
value of imports in spite of the rise in prices, and a rise in British exports of $£ 14,000,000$, or nearly 59 per cent. It is interesting to compare this modern extraordinary progress of the most ancient British industry with its painful struggle in the old days under high Protection, when we vainly endeavoured by fiscal means to prevent our raw wool from going abroad, and sought by steps equally futile to prevent Continental woollen goods from coming in. Mr. Chamberlain's "wool is threatened" might with reason have been written of the Protectionist England of, say, 1750 .

We turn to cotton, and against an increased importation of $£ 6,000,000$, we see an exportation rising from $£ 69,700,000$ to $£ 127,200,000$, a gain of $£ 5 \%, 500,000$. It is a rise which has made many fortunes in Lancashire, and we need not be surprised that those who work in the industry are not enamoured of fiscal change. But the case of silk is fully as significant. Mr. Chamberlain said that silk had "gone" ; he might with truth have said that it was about to take a new lease of life. The imports of silk, in spite of rising prices, have fallen in value in $1900-13$ by $£ 700,000$. At the same time the exports of British silk have slightly increased. In these years we 
know that the consumption of silk must have increased considerably, for there have been great trade prosperity and a large addition to the national income. It follows that the decreased imports point to an increased consumption at home of British silks.

Very much the same verdict would seem to be true of the glass industry, in which, as in the silk industry, our imports exceed our exports. It will be observed that in 190013 there was a slight increase in the value of glass imports, while glass exports rose considerably. The consumption of glass at home must have risen in the thirteen years, and it follows that the British industry must have been strengthened in the period. The glass industry is one in which, in some branches, we have been much behind the Continent in point of technique, as has been shown by the evidence of trade experts, and it has still much to do before it can be considered in a satisfactory condition.

We come next to boots, the small imports of which have slightly risen, while the exports have increased by no less than $£ 2,700,000$. It may be usefully observed that this industry is one whose materials are in every case manufactured articles, and that it would be heavily penalised by any import duty on such articles. 


\section{MR. CHAMBERLAIN'S CASE 261}

Thus the sober examination of trades selected as examples of decadence, not by Free Traders, but by the great modern protagonist of Protection, gives eminently satisfactory resultssatisfactory, that is, under existing conditions of competitive production; I have necessarily to employ relative terms, as will be understood from the study of production which opens this volume. To take the matter further, I have added the statistics for all articles classified as "manufactures" by the Board of Trade. It will be seen that imports have increased by $£ 54,000,000$, while exports have increased by $£ 183,300,000$. Both imports and exports of "manufactures" consist very largely indeed of articles which are raw materials bought by manufacturers to use as materials. I pointed out in 1903 that out of $£ 113,000,000$ worth of manufactures brought in in 1902 for home consumption, as

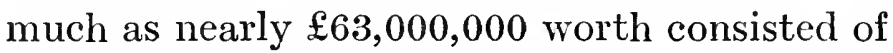
materials and plant used in British industry. A subsequent and independent analysis by the Board of Trade entirely confirmed my statement on this head. The $£ 164,000,000$ worth of imported manufactures of 1913 were for the most part employed in British industry.

Faced with the difficulty of distinguishing 
between a manufactured article and a raw material in framing a tariff, Mr. Bonar Law in a recent speech (February 7, 1913) assures us that foreign countries have made the distinction "without the slightest difficulty." This is a curious view of the facts of the case. The point has always been found insoluble in the construction of tariffs, and in the making of American tariffs, as in the making of German tariffs, there has been no solution, but merely a victory for certain sections of would-be monopolists over certain other sections.

Accomplished facts have thus played havoc with the representations and illustrations with which the Protectionist case was launched, but quite apart from the trend of our trade in the last ten years, the case for Protectionalways difficult to defend-has peculiar weakness in relation both to the special case of the United Kingdom and the special case of the British Empire.

§ 2. The Later Developments of Tariff REFORM

If we consider the United Kingdom as a unit, we have the case of a country of small 


\section{THE LATER DEVELOPMENTS 263}

area with but two considerable gifts, the first of which is coal, and the second of which is seaboard. Possessing coal, and what is more, possessing easily won coal situated near the sea, Britain is naturally a well-found workshop, for it is an easy matter to bring to its coal the raw or manufactured materials of the entire world, and to work upon them economically. That simple truth makes a policy of free imports an obvious advantage. Given free imports, the coal and the seaboard can be put, with due intelligence, to their most fruitful uses. It is not contended here that the most fruitful use necessarily results, and indeed all our considerations here are conditioned by competitive individualistic industry. How best to employ power and inventions is a much wider and nobler issue than any connected with fiscal matters, and it is discussed elsewhere in these pages.

Passing from the consideration of the United Kingdom as a unit to the British Empire as a whole, we see that a common protective policy is impossible of application. Where the German Empire presents divergences of economic development no greater than, if as great as, are to be found in the United Kingdom, the British Empire, scattered as it is all over the world, presents every possible 
diversity of economic situation. It is impossible to frame for it a common protective tariff, and the spirit of protection can only serve to accentuate its economic differences and promote political cleavages. There is only one possible fiscal basis for a British Imperial union, and that is Free Trade-not Free Trade in the perverted sense of the denial of import duties for revenue if such be necessary, but in the true sense of the denial of the establishment of protective Customs duties.

Further, to deal with the British Empire as we find it, the agitation for Preference finds the Mother Country in possession of complete Frce Trade, India and the other British possessions, for which Imperial rule is directly responsible, also without protective duties, and the self-governing Colonies each practising Protection against all the world, including the British Empire, in various degrees. Quite apart from the inherent difficulties and objections already stated, therefore, the attempt to set up a working system of Preference in the Empire as it is to-day, demands from the various parties to the suggested bargain strongly contrasted sacrifices equally repugnant to each of them. The United Kingdom is asked to lay down Free Trade and to tax foreign products in order to create duties to be reduced or 


\section{THE LATER DEVELOPMENTS 265}

repealed in favour of the Colonies. The selfgoverning Colonies are asked to give up, in favour of the British manufacturer, part of the very Protection which the agitators for Preference assert to be indispensable for the Mother Country itself, although it is an old and developed industrial nation. The people of India are asked to deny themselves the Protection claimed by the self-governing Colonies, even while they see the people of the United Kingdom enacting a tariff as a prime necessity for themselves.

The many mutations through which the Unionist policy and representations have passed during the last ten years are a natural consequence of the inherent difficulties which $I$ have stated broadly in a few sentences.

Mr. Chamberlain proposed to tax foreign food and to let Colonial food go duty-free in order that the Colonists might gain a turn in price. At the same time he preached Protection for British industries against foreign competition. At the same time, that is, he gave cause for the British agriculturist to ask why he should not be protected, not only against his foreign competitor, but against his Colonial competitor. The very Tariff Commission which Mr. Chamberlain himself founded, took his food programme and enlarged 
its scope far beyond corn, and meat, and dairy produce, while claiming that Colonial food as well as foreign food should be taxed. This they did in 1905 (Report of the Agricultural Committee of the Tariff Commission, Vol. III., par. 394). So that within two years what began as an Imperial policy of setting up "ties of interest" for Colonial food-producers, changed out of all knowledge into the erection of a barrier between Colonial food-producers and the British consumer.

Or consider the element of disruption which cnters in connection with the Irish question. The economy of Great Britain is based upon coal, but Ireland is coal-less, and, therefore, as soon as Protection is accepted, Ireland must claim, whether Irish affairs be governed from Westminster or from College Green, a special Protection suited to her needs. In the volume "Against Home Rule" published in 1912, we find Sir Edward Carson thus exploiting the conception that Protection demands British duties upon Colonial products :

"I think, however, it would be desirable to point out that in dairy produce and poultry, in barley and oats, in hops, tobacco, sugarbeet, vegetables, and fruit, in all of which Ireland is especially interested, Irish products would have free entry into the protected 
markets of Great Britain. Canadian and Australian products would of course have such a preference over foreign competitors as a Home Rule Ireland might claim, but it is only under the Union that Ireland could expect complete freedom of access to our markets."

Here we have it perversely argued that the Free Trade which exists between Prussia and Bavaria, or between Austria and Hungary, or between Piedmont and Sicily, may not be enjoyed by federated states of the British Empire.

Equally to be deprecated are the suggestions which have arisen again and again that Imperial Protection for the United Kingdom should be ushered in through the doors of an Imperial Conference. This suggestion was first heard of in 1904, when apparently Mr. Balfour made it to postpone indefinitely the practical consideration of the subject. He countered Mr. Chamberlain by suggesting that in view of the many difficulties of the'subject-he has never ceased to harp upon its difficulties-a policy of Preference could not be arrived at without a Colonial Conference, at which the hands of every delegate should be free to discuss the subject on its merits, and that, if and when at such a Conference a practical 
solution of the many difficulties was arrived at, that practical solution should be referred not only to the electorate of the United Kingdom, but to the electorates of each of the Colonies.

At Ashton-under-Lyne, on December 16, 1912, Mr. Bonar Law went further and made the deplorable suggestion that the Colonies should be made directly responsible for the imposition of food duties in the United Kingdom. The course of events was briefly thus. The Government had suffered a defeat on the Home Rule Bill in a snap division on November 11, 1912. It happened that a meeting of the National Unionist Association had been convened at the Albert Hall for November 14, and this mecting, therefore, found the Unionists in a fervour of excitement, eagerly anticipating the downfall of the existing Government. The situation carried Mr. Bonar Law and Lord Lansdowne off their feet, and between them they elaimed in plain terms that if they regained power they would consider themselves free to impose duties on food. Lord Lansdowne put it that if the Colonies:

"Ask us to give them a moderate duty upon foreign wheat, sufficient to bring into our markets the great unlimited granaries of Canada and Australia, we shall not be deterred 


\section{THE LATER DEVELOPMENTS 269}

from examining their proposal by the mere statement that it will involve the taxation of food, and that all food taxes are unholy things."

It was at once made plain that a considerable, and indeed a large, section of the Unionist Party did not care to face a fourth consecutive General Election with food taxes on their backs. Headed by Lord Northcliffe's organs, a portion of the Unionist press revolted.

The return of $\mathrm{Mr}$. Tom Taylor as Liberal member for Bolton on November 23, 1912, added to Tory dismay, and at Ashton-underLyne, on December 16, Mr. Bonar Law sought to lay the storm by casting upon the Colonies the onus of imposing food taxes. He explained that what Lord Lansdowne really meant was :

"If our countrymen entrust us with power, we do not intend to impose food duties. What we intend to do is to call a conference of the Colonies to consider the whole question of preferential trade, and the question whether or not food duties will be imposed will not arise until those negotiations are completed. We are told that the Colonies have made no offer, that they do not wish such an arrangement. If that is true, no food duties will be imposed in any circumstances."

This speech was not unfairly headlined by 
the Daily Mail: "No Food Taxes, Unless Over-Seas Dominions Insist." At home and in the Colonies a chorus of repudiation followed what a Canadian organ not unjustly described as Tory "manœuvring," and it became necessary for the Unionist leaders once more to shift their position. A memorial, signed by 229 members-nearly the whole of the Unionist party in the House of Commons-begging that food taxes should not be made an issue at the next General Election, was presented to the Unionist leader on January 10, 1913. On January 13 Mr. Bonar Law replied, eonsenting, if returned to power at the next General Election, not to impose food duties until after a second General Election. The suggestion remains, however, that the proposals to be submitted to the electorate at the second General Election should be the result of bargaining at a Colonial Conference, and it is a suggestion which is not only repudiated, but is universally disliked by the Colonial demoeracies, who, whatever may be their own views as to Protection, resent the idea that they should be dragged into the false position of being made partisans to the setting up of food taxes in the United Kingdom.

The shifting of food taxes by a return to an unfortunate variant of Mr. Balfour's proposals 


\section{THE LATER DEVELOPMENTS 271}

of 1904, however, merely lays one Protectionist difficulty to raise another. The abandonment of food taxes to barter for the votes of Lancashire and other centres of industry is to destroy the support of Tory landlords and farmers, who have been promised the protection of all kinds of food, from corn and meat to potatoes and fruit. As to the towns, it may be said that the net has not merely been spread, but manufactured in sight of the bird, and as to the rural districts, if there is any virtue in the doctrine of Protection at all, it is agriculture and not industry which in the United Kingdom stands in need of Protection.

The grievance of the deserted British farmer was accentuated by the speech at Edinburgh on January 24, 1913, in which Mr. Bonar Law once more outlined a Unionist policy, prefacing it, with some humour, with the statement that " our policy in regard to Tariff Reform is perfectly definite, and it is supported now by the whole Party with a unanimity which has never existed since this controversy began."

Three things would be done, Mr. Law said, if the Unionists were returned to power :

(1) They would " impose a moderate tarifflower than exists now in any industrial country in the world-on foreign manufactured goods."

(2) They would "give to the Dominions 
the largest preference which is possible without the imposition of new duties upon food." In accomplishing this they would "impose no new duties on the food of the people, but on the contrary take off some of the food duties."

(3) They would " endeavour to establish Imperial co-operation in trade as well as in defence," working out the plan with the Colonies.

The difficulty of distinguishing "manufactures" from "raw materials" has been already referred to. The great body of the goods imported into Britain are bought not by or for retailers, but by manufacturers to use as materials. To name one illustration which may be given out of thousands, a duty on cement has been promised by the Tariff Reformers to the clectorate of Rochester. Foreign practice as to taxing cement varies enormously. Germany and Belgium do not tax it; America taxes it at 5 per cent. ad. val.; France taxes it at about $4 s$. a ton. In this case our Protectionists have promised a worse tariff to the United Kingdom than exists in Germany-a tariff which would badly hit the building and engineering trades.

And observe that the British farmer is deliberately sacrificed. He is to be taxed sleeping and waking through the operation of 
duties on goods, while denied tariff profits on food in compensation. It will be surprising if the Tories in the shires do not have to pay dearly for so indefensible a desertion-especially indefensible from the Protectionist point of view-of a great British industry.

As to the second point, the suggestion that a Preference which is not a hollow mockery can be granted to the Colonies without the taxation of corn, meat, and dairy produce, will not stand a moment's examination. It is as true to-day as in 1903, that "if you want to give a preference to the Colonies, you must put a tax on food." In view of the fact that the self-governing Dominions do not produce tea, coffee, or cocoa, and that their export of sugar and wine is small, the suggestion that a Colonial preference can be granted on these things can only be regarded by our Colonists as an insult to their intelligence.

The suggested Preference on the existing revenue duties would be absurd enough if it stood alone, but let us observe, that the munificent offer to the Colonies is accompanied by a promise to the British workman that the basis of the offer is to be destroyed. The home consumer is told to hope that Unionists will "take off some of the food duties." India is to have a preference on tea, and again, she 
is not, for the tea duty is to go. The West Indies and Australia are to have a preference on sugar, but again, they are not, for the sugar duty is to go. It is black, and again, it is white. The late and lamented Mr. Craig, who used to frequent the Oval and Lord's, and make neat little speeches to cricketing crowds, never failed to please when he ended his droll oration by saying: "That's my opinion, ladies and gentlemen, but if you don't like it, I'll alter it." It was an exeellent plan for catching pennies, but I doubt its efficacy as an appeal to the electorate.

As to the third point, the outburst of indignation in the press of Canada, South Africa, and Australia, which has been eaused by the Unionist political manœurring with which I have dealt, shows that Colonial statesmen will never consent to eome to an Imperial Conference to take counsel how to impose unjust burdens upon the British poor.

'The outcome of ten years of fiscal controversy has thus been to strengthen enormously the position of Free Trade in the United Kingdom. 'That is an Imperial as well as a British good. The greater part of the trade of the Empire-all of it save Imperial imports into the self-governing Dominions-is already carried on under Free Trade conditions. To 


\section{THE LATER DEVELOPMENTS 275}

destroy Free Trade in the United Kingdom would be to destroy the large measure of Free Trade within the Empire which already obtains, and which may be easily enlarged. Because the States of the German Empire are contiguous, the absurdity of Protection between them is universally admitted. Because the States of the British Empire are widely sundered, the absurdity of Protection between any of them does not so obviously appear. In real truth, however, Protection within the British Empire is as unjustifiable and unnecessary as Protection between Saxony and Bavaria. The Unionist disasters of the last ten years may be regarded as happy auguries that the time will assuredly come when the exchange of products within the British Empire will be as free as it can be made by that greatest of all agents of Free Trade-the engineer. 


\section{XII}

\section{THE SINGLE TAX}

$\S 1$. The Single Tax Statistically Impossible

THE Single Tax doctrine, which, in brief, 1 is that the land of a country is the sole source of its wealth, and that the only proper revenue of a State is that derived from the appropriation of rent, is the strangest delusion that ever masqueraded as a gospel. It did not originate with Henry George, as is supposed by those unread in economic history, but with the Physiocrats, the school of French economists founded by Quesnay, who was born in 1694 and died in 1774. But Quesnay was a brilliant man and a thoughtful, and it would be utterly unjust to his memory to assert that the Single Tax doctrine was in his day an absurd doctrine. I have given the date of his death. Let us bethink ourselves how the most advanced races in the world stood as wealth producers at the time of Quesnay's death. In 1774 the English people had but recently discovered how to smelt coal 


\section{STATISTICALLY IMPOSSIBLE}

with iron, and the Industrial Revolution, like the French Revolution, was yet to be made, although the ferment of men's minds in science and in politics was inevitably leading up to these tremendous phenomena. The world of Quesnay was an agricultural world, and the school of economists which he founded was as right at that time in stating that the wealth of France or England was derived solely or mainly from land as the Single Taxers of to-day are wrong in making the same statement of these countries. The case is on all fours with the fate of the doctrine of Malthus. Malthus was born in 1766 and died in 1834, and when he published his famous essay on population in 1798, he was right in holding that population tended to increase more quickly than the means of subsistence could be multiplied. For Quesnay, who died in $17 \% 4$, and for Malthus, who died in 1834, the world was a place in which it was exceedingly difficult to produce and amass wealth. In the day of Quesnay it needed the produce of a whole countryside to sustain one rich lord or baron or squire, and such wealth as was produced was mainly the produce of the soil, other interests being subsidiary to agriculture and minor factors in the affairs of men. Man, indeed, was for the greater part, even in white 
civilisations, very near the primitive savage in point of his use of the world.

As from about the middle of the eighteenth century, however, the prospects of mankind, and man's use of the world, took on an entirely new aspect. A scientific age was ushered in, and the march of science was so rapid in the nineteenth century, and that march is proceeding at a rate so greatly accelerated in this our twentieth century, that it has long ceased to be true that land is the chief source of wealth of a great modern nation, and every day the wealth of the great nations is being derived less from land and more from labour exercised upon clever inventions with the aid of Capital. In the poor and very poor countries of the world, however, the condition of things is very much where it was in the days of Quesnay. Look round the world and find the populous agricultural nations, and you also find the populous poor nations. It is in India and China and Russia that dire famine stalks periodically, and it is in the great modern industrial nations, which do not derive their wealth from land, in which subscription lists are opened to help the poor people who are still exponents of the arts of the world as they existed for Quesnay. Our Single Taxers 
are just belated physiocrats who do not understand the economic development of such a nation as this, and who prate of land and of landlords' exactions in a country which, fortunately for itself, has long ceased to depend on land for its livelihood, and in which the landlord has been dethroned from his old position of sovereignty.

In new lands, such as Canada and Australia, tiny populations draw wealth from vast territories; their case is not our case, but their case will come to be the same as ours with the efflux of time.

If what I have said above is true, it must follow that the total of land rents in the United Kingdom must be comparatively small. And so it is, as is very easily demonstrated. Here is a liberal estimate of the land rents of the United Kingdom :

What British Land Rents Amount to (Circa 1913)

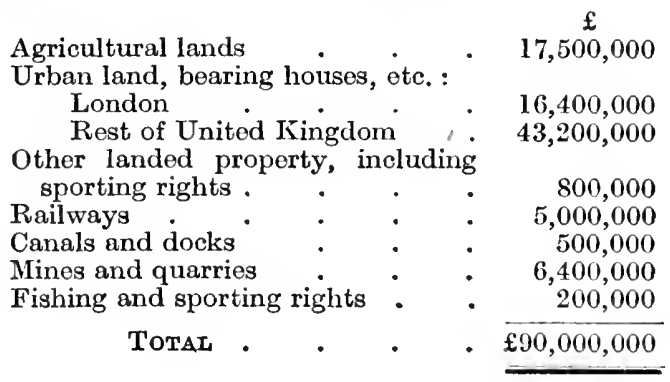

It will be seen that I have included every 
sort and kind of rent derived by landlords for the use of their land. The aggregate, which amounts to no more than $£ 90,000,000$, includes all the rents paid for land used for industry, whether for factories or mills or workshops or warchouses or shops or railways. It also includes all the mincral royalties and wayleaves paid by those who get coal. It also includes all the rents received by landlords for sport or plcasure. It also includes all the rent paid for land upon which houses stand.

For many years, and indeed until the publication of my Riches and Poverty in 1905, the statements made by Single Taxers as to the aggregate of rent in the United Kingdom were very greatly exaggerated. The total was commonly stated as $£ 300,000,000$ or $£ 400,000,000$, and it was through believing in this imaginary figure that many people became Single Taxers, holding that if landlords really drew three or four hundred millions in rent, the sooner they were relieved of a large part of it the better. Since 1905 Single Tax statements as to British rent have been toned down a good deal, but I am sorry to say that the old figures are still sometimes recklessly put forward.

It will be seen that the true estimate of 


\section{STATISTICALLY IMPOSSIBLE 281}

British rents at once reveals the practical impossibility of Single Tax. The public expenditure of the United Kingdom is as follows :

$\mathfrak{E}$

True National Expenditure, Post

Office outgo not counted (1914-15) 183,000,000

Rates raised by Local Authorities (about)

$81,000,000$

Total . . . . $\overleftarrow{\$ 264,000,000}$

As the total of British land rents is not more than $£ 90,000,000$, it will be seen that, if the whole were confiscated to-morrow, there would be a neat little balance of $£ 174,000,000$ to find from other sources of taxation. Land rents are barely large enough to cover local rates.

Some Single Taxers, faced with my estimate of rent, have thought it well to hedge on the subject by alleging that the total rents now received by landlords are not a true measure of taxable land value, because much land is not put to its "best use," and that much land round towns is "held up" which ought to yield more rent. This comical assertion that the landlords, commonly pictured as extortionists, are not extorting all that they might, has its humorous side; but to deal with the argument as seriously as one can, it will be perceived that even if one-third were added to the aggregate of existing rents on the supposition that some land may be let at a 
higher figure, the total would still lamentably fail to reach the sum necessary to meet public expenditure.

It is of great interest to compare the aggregate of British land rents with the National Income. The National Income (1914) is about

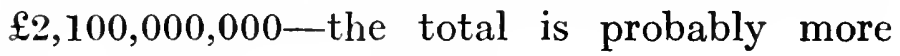
rather than less than this.

We thereforc get the following striking comparison :

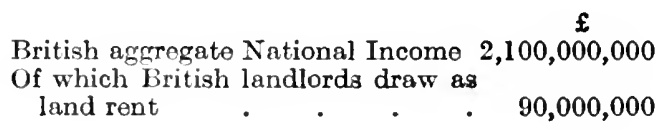

That is to say, rent amounts to no more than $4 \frac{1}{2}$ per cent. of the total National Income. It comes to this, then, that the Single Taxers of the twentieth century actually propose to $\operatorname{tax} 4 \frac{1}{2}$ per cent. of the National Income and to excuse the remaining $95 \frac{1}{2}$ per cent. from taxation. It is finance pour rire.

It will be seen how the actual facts of the British case in 1914 bear out in concrete the general statement with which I opened this subject. The statement of fact, like the statement of theory, is conclusive against the Single Taxers. It is not even one of those cases that have two sides to them. Single Tax can only be given credit by one who has not 
acquainted himself either with economic history or with the actual facts relating to life and work as they exist in the United Kingdom at this hour.

It is almost superfluous to proceed with the statistical side after what has been said, but it may be well to set out the official analysis of the estates of those who died leaving property, for the most recent financial year for which statistics are available, that ended March 31, 1912, as given by the Inland Revenue Commissioners :

Gross Capitat Values of the Principal Descriptions of Property Passing at Death in a Year

1. Stocks, funds, shares, and other like securities $\quad . \quad . \quad . \quad 143,757,33 \mathrm{~s}$

2. Cash in the house and in bank : $\quad \begin{array}{rr}0 & 19,840,987\end{array}$

3. Money lent on mortgages, bonds, bills, etc. $\quad 20,265,134$

4. Trade Assets-i.e. book debts, stock, goodwill, etc. . $. \quad . \quad .16,376,778$

5. Policies of insurance $\quad \cdot \quad \cdot \quad \cdot \quad \cdot \quad$ : $\quad . \quad 10,242,325$

6. Household goods, appareI, etc. $\quad$. $\quad 8,597,440$

7. Agricultural land . . . . . $\quad$. $16,747,384$

8. House property and business premises - $42,997,591$

9. Ground rents and other similar charges . $\quad 5,144,991$

10. Other property . . . . . . $22,698,470$

Total Gross Capital Valdes . . $\overline{£ 306,668,438}$

The above values are gross; the net values (i.e. net after payment of any debts due by the deceased) passing in the year were

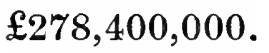

The land under taxation comes mainly under the headings $3,7,8$, and 9 . A fraction only of 3 , of $\%$, and of 8 consists of land, for 
the mortgages are mortgages on houses as well as on land. The value of the agricultural land includes not only the land, but all the buildings and improvements on it, and the house property and business premises, of course, consist only as to a minor part of the value of land. We thus have it proved by the Death Duty returns, just as it is proved by the Income Tax returns, that land plays a comparatively small part in the wealth of the United Kingdom.

\section{§ 2. Some General Considerations}

We have seen how Single Tax fails by rcason of the changes wrought in the economy of modern great nations by the industrial revolution, and I have shown that statistical evidence demonstrates the impossibility of Single 'Tax as a practical policy. It is now of importance to consider the foundations of British wealth as it exists to-day.

What is British wealth built upon? The answer is a plain and a simple one, and is given elsewhere in these pages. British wealth is mainly derived from our possession of coal. Until Britain used her coal, she was a poor 


\section{SOME GENERAL CONSIDERATIONS 285}

agricultural country with a stationary population and no prospects. That was Britain's condition in the middle of the eighteenth century, when Quesnay was a Single Taxer. But, says the Single Taxer, is not coal " land "; is it not got from the teeming bosom of Mother Earth; is it not one of the "divine gifts" which figure so largely in Henry George's rhetoric? Any man can answer these questions for himself by setting out to get coal in the United Kingdom. He will find that the alleged " gift of God," the piece of "land value," is hidden so deep in the bowels of the earth that he may not come to it unless he employs a great amount of capital.

But to do industrial work you need not only coal but raw materials, such as cotton, wool, hair, jute, hemp, flax, timber, iron, copper, zinc, tin, and many other metals, indiarubber, guttapercha, hides, skins, oils, and other things too numerous to mention. Now, the fact about land, and it is another fact which by itself entirely disposes of Single Tax, is that this land of ours either does not produce these materials at all, as in the case of cotton and hemp and jute and rubber and palm oil, or produces them in insufficient quantities, as in the case of iron and tin and wool, or produces them in ridiculously small and negli- 
gible quantities, as in the cases of copper and zinc. Fully seven-eighths of the raw materials used in British industry to-day are imported from places abroad. They are the produce, not of the land of the United Kingdom, but of other lands, in which no Single Tax levied by a British Government can run. I have seen it alleged that the materials used in British industry pay "toll to British landlords." The facts of the ease, as it will be seen, entirely dispose of this, for practically the whole of the materials we use come from abroad, and their production contributed not a penny to United Kingdom rents.

Again, when we examine the case of food, while we are less dependent for food than for materials upon places abroad, it is true that about one-half of the food we eat (of such kinds as we can grow ourselves) is imported. But the priee of all food, or nearly all food, is ruled, not by supply and demand operating in the United Kingdom, but by supply and demand operating in the world at large. That follows from the fact that we are a Free Trade country, and that by virtue of free imports we obtain food at the lowest world price. Consequently, British agricultural rents are low, for they have fallen in the Free Trade era with the great fall in the price of food. 


\section{SOME GENERAL CONSIDERATIONS $28 \%$}

Even the recent rise in food prices leaves food exceedingly cheap as compared with the prices which obtained half a century ago. Here we have another reason why the British landlords' toll is kept within small limits. Free Trade reduced British agricultural rents, and made it impossible for the landlord to screw up the rent of land through the operation of artificially high prices by protective duties. The whole of the agricultural rents of the United Kingdom amounts to no more than about $£ 52,000,000$ gross, and this covers the rent of the lands with all the buildings and improvements upon them, including farmhouses, drainage systems, fences, and everything else. Not more than about $£ 17,000,000$ of this, and probably less, is true rent of land. We have the truly extraordinary fact that, because of Free Trade, all that British landlords in our wealthy country derive from agricultural rents is this relatively insignificant sum.

There are some people who say: "We are not Single Taxers, we merely believe in the taxation of land values." The fact about the special or penal taxation of land values is that it is Single Tax plus more or less water. The "taxation of land value" movement is led by avowed Single Taxers, who desire the special taxation of land values as the thin 
end of the wedge. Unfortunately, even in a modified form, the Single Tax is capable of producing most injurious results, and its operation must injure many deserving people while letting off the very people who have mainly gained through the existence of British land values.

Take, for example, the case of a British landlord who, owning many acres which came to be the site of an industrial town, sold out land over a long period to large numbers of rich and poor people. This is a real and very common case. In such an instance, the present owners of the land value are obviously people who did not gain by the main rise in the price of urban land. Yet they are the persons who would be taxed by the Single Tax, while the original landlord, who pocketed the land value, would escape entirely.

Or consider the case of mortgages. An enormous number of large and small landed properties in the United Kingdom are mortgaged, and in many cases mortgaged for the greater part of their value. This is especially true of poor people owning houses. The Single Taxers would hit, not the mortgagee, who by lending money on the land and property has become the real owner of the greater part of it, but the poor mortgagor. Take a landed property 


\section{SOME GENERAL CONSIDERATIONS 289}

worth $£ 600$ which is mortgaged for $£ 400$. In such a case the real effect is that the mortgagee owns 400 pounds' worth of property, and the mortgagor owns 200 pounds' worth. The mortgagor, although owning only one-third of the property, would have to pay the whole of the land values tax, while the mortgagee would draw his interest scot free of the tax. (Compare "We look upon interest as natural and just." -Henry George.) I recently heard one of the leaders of the Single Tax movement in this country, a member of the House of Commons, challenged on this point in a discussion before an important political organisation, and he admitted that the effect would be as stated here.

The crowning folly of the Single Tax is that it would seriously menace the existing amenities of towns.

When we say that we tax land or any other commodity, we really utter an absurdity. No inanimate thing can be taxed, and all we have power to do is to levy taxes upon persons. A tea tax is a tax levied upon a person who possesses tea. A land tax is a tax levied upon a man who possesses land. Suppose we concentrated, or attempted to concentrate, all our taxation upon tea. The obvious effect would be that people would avoid using tea, as the 
less tea they used the less they would be taxed. And so it is with land. If we concentrate, or attempt to concentrate, taxation upon persons owning land, people will avoid land as far as they possibly can. For example, suppose a man is building a house. He has the land to consider and the building to consider. If in respect of the building he is not taxed while in respect of the land he is alone taxed, it is most obvious that he will use as little land as possible in order to avoid taxation.

Land values taxation, or the Single Tax, is thus the enemy of gardens, the enemy of open spaces, the enemy of decent town life, and the enemy of health. It is the friend of the slum, the friend of the sky-scraper, the friend of city concentration.

This case against land value taxation has been admitted by some Single Taxers in framing Bills for the taxation of the rating of land values, in which they have taken care to exempt gardens from taxation. The admission, of course, is a grave accusation against the whole policy.

There is only one true test as to the justice of taxation, and that is that it should have regard to ability to pay. Whether we require revenue for Imperial or for local purposes, our only business is to ask what a man can 


\section{SOME GENERAL CONSIDERATIONS 291}

afford to pay and to tax him accordingly. (Observe, however, that local beneficial rates are not really "taxes," and in levying for them regard should therefore be paid to "benefits received" as well as to "ability to pay"; this important point is recognised in German local taxation). A moment's thought will show that if it is true that landlords take the greater part of the wealth of a country, they must be the chief rich men of the country, and if therefore we tax with regard to ability to pay, we tax landlords. The chief wealth in the country is, however, possessed by capitalists and not by landlords, and what the taxation of land values seeks to do is to excuse capitalists from the whole or part of the taxation which they ought to bear.

Take, for example, a town the chief industries of which are run, as is so frequently the case, by a few capitalists. These capitalists profit chiefly by the work of the people of the town, and they have the largest incomes drawn in the town. The rating of land values would seek to excuse them from taxation on their wealth. It would seek wholly to excuse them from rating, save in respect of the small sites upon which their businesses are carried on, and then only if they are the owners of those 
sites! Thus the people in the town best able to support the town would be let off, and if the town confined itself to taxing local rents, it would be in a beggarly position.

There are several cant terms used by the Single Taxers which may usefully be subjected to examination. The first is that a man ought not to be taxed upon "improvements." What is an "improvement"? The answer is that it is a piece of capital. A house, a mill, a factory-these are "improvements," and the Single Taxer secks to gain the support of eapitalists and owners of property, large and small, by suggesting that they can escape from taxation by adopting Henry Georgeism. The answer is, of course, that by the owners of improvements we mean capitalists, and by the untaxing of improvements we mean the untaxing of capital-i.e. the untaxing of those people in the country best able to bear taxation, whether for Imperial or local purposes. If a man builds a fine house, it is a proof of his ability to bear taxation. If a man has a great factory filled with fine machinery and employing hundreds of thousands of men, it is a proof that he is able to pay (although, of course, we should always endeavour to relate these evidences of wealth to the profits actually made, as is done in Germany, where 


\section{SOME GENERAL CONSIDERATIONS 293}

an income tax is levied both for Imperial and for local purposes).

Another cant term is that the Single Tax would force land into its "best use." As a matter of fact, the appropriation of rent by the State would bring about no such effect. Take, for example, a piece of land in Scotland in demand (1) by crofters and (2) by a rich American millionaire for sporting purposes. The Single Tax doctrine is that the State should not control the use of land, but simply ask the highest rent it could get. In the case quoted, which is typical of many other cases, the American millionaire could obviously pay more than the Scotch crofter for the land, and so the land would not be put to its best use.

The social use of land for town areas is now the most important use of land in the United Kingdom. To secure it a city should own and control its area; this ownership and control the Single Taxer would deny.

Finally, the assertion that the Single Tax would make land cheap does not bear examination. It is forgotten by those who make the assertion that, while it is true that if you lay a tax on a man because he owns land, he will be more eager to sell it than he was before, and may therefore put it into the market 
at a lower price than would otherwise be the case, the buyer of the land, although he got the land cheaper because of the tax, roould have to pay the tax. 'Therefore the land would be no cheaper than before, and what we should have done would be to take something from the seller and give it to the buyer, with no guarantee that any social good would arise from the change. But that is not all. If the tax is to be progressive until the whole of rent is appropriated in the Single Tax, as is suggested, then, even at the beginning of the operation of the first tax, people would not be more eager to buy, but less eager to buy, because they would be fearful that the tax would be increased after they had bought. In short, the rule holds good that if you levy taxation upon persons through their ownership or use of any particular commodity, they will use that commodity as little as possible.

Lest any one who has not before studied the subject should imagine that I have dealt too hardly with Single Tax, let the Single Tax prophet himself be heard. In The Condition of Labour Henry George gave the following concise definition of his policy, and it should be taken to heart by every one who is tempted to listen to Single Tax proposals :

"We have no fear of capital, regarding it 


\section{SOME GENERAL CONSIDERATIONS 295}

as the natural handmaiden of labour; we look on interest itself as natural and just; we would set no limit to accumulation, nor impose on the rich any burden that is not equally placed on the poor ; we see no evil in competition, but deem unrestricted competition to be as necessary to the health of the industrial and social organism as the free circulation of the blood is to the health of the bodily organism-to be the agency whereby the fullest co-operation is to be secured. We would simply take for the community what belongs to the community, the value that attaches to land by the growth of the community; leave sacredly to the individual all that belongs to the individual; and, treating necessary monopolies as functions of the State, abolish all restrictions and prohibitions save those required for public health, safety, morals, and convenience."

The book in which this passage occurs illustrates the Georgian definitions. It was written by Henry George in reply to a Papal Encyclical which commended to all Christendom the protection of labour, and especially the labour of women and children. Henry George replied to the Pope, in effect, that it was all nonsense and worse than nonsense to protect labour-all that was wanted was Single Tax! It will be seen that Ifenry 
George defends the accumulation of wealth, that he defends interest, and that he is opposed to proposals to tax the rich more than the poor. He would sweep away all factory inspection, labour laws, and other legislation, in the conception that to tax land would set everything right! He extols competition. It is difficult to speak of these things with patience.

To sum up, the Single Tax is condemned on historical and economic grounds. It is absurd, because the main part of the wealth of the United Kingdom is derived not from land, but from labour exercised with the aid of inventions embodied in eapital. It is impossible, because the whole of British land rents, if appropriated, would not cover one-third of British public expenditure. 


\section{N D E X}

Acting in The Great State, 52

Advertising, waste in, 31, 33

Ageing workers under minimum wage, 186

Agriculture, census of, 2

- employment in, 102, 103, 105

- minimum wage, 162

- Mr. Chamberlain on, 256

- number of workers, 10

- production of, 5, 6, 98

- relation to wealth, 94

- science of, 160

- under Protection, 272

- wages, 137-145

Amateur work in The Great State, 51

America, national expenditure, 229

- urban population, 100

American Bureau of Labour Statistics on waste in flour trade, 70

Apprenticeship, 46, 50

Army, expenditure, 224

Art in The Great State, 53

Askwith, Sir George, on minimum wage, 166

Back to the land, 111

Bacon, price of, 205

Bank deposits, 207

Bankers' clearances, 210

Beef, cost of distribution, 78

- price of, 205

Belfast, sweating in, 192

Bill of Exchange, 207

Board of Trade, relation to Wages Boards, 168-176

Bonar Law, Mr., quoted, 268, 271

Boots, cost of distribution, 77

- exports of, 257

- imports of, 257

- Mr. Chamberlain on, 256
Bowen, J. Chester, on cost of wheat distribution, 70

Box-making, 177,184

Boys engaged in production, 12 , 14

Britain, origin of wealth, 96

British Empire, fiscal policy, 263

Building, employment in, 19

- production of, 4,16

Cadbury, Mr. George, 175

Calendering, 188, 189

Canada, free land in, 119

Capital, defined, 89

- left at death, 283

- nature of, 88

- not reproductive, 89

- physical properties of, 89

- relation to ideas, 84

- relation to produciion, 85

Capitalist washerwomen, 188

Capitalists, sovereignty of, 110

Carpet, price of, 75

Carson, Sir Edward, on InterImperial Protection, 266

Cash Registers, 124

Cement, import duties on, 272

Census of Agriculture, 2

Census of Production, 1

Chain-making, I 77, 178, 180, 181

Chamberlain, Mr. Joseph, case for Tariff Reform, 248

- on agricultural depopulation, 100

Chemical trades, production of, 4 Cheques, 207

Clothing trades, production of, 4 Coal, basis of British wealth, 26

- influence on agricultural wages, 143

- Mines Minimum Wage Act, 170

- price of, 205

- trade, 69 
Cocoa, price of, 205

Colonial Preference, 248-275

Colonies, relation to fiseal policy, 250-255

Commereialism and honesty, 121

- relation to science, 22

Competition, waste of, 64-80

Compulsion in 'The Great State, 51

Conscription for arduous labour, 57

Co-operation, 65

- need for, 82

Copper, price of, 205, 206

Corn, imports from colonies, 254 , 255

- price of, 146, 205

Cotton, Mr. Chamberlain on, 256

- price of, 205

Cotton-embroidery trado, 188

Cottons, exports of, 257

- imports of, 257

Cradley Heath, ehain making, $177-182$

Crodit, coining of, 207

Curreney, 207

Daily New and Minimum wage, 175

1)earness, the Now, 195-215

Death rate, relation to land question, 114

Dilke, Sir Charles, and minimum wage, 174

Distribution, small possible cost of, 77

- wasto in, 64-80

Division of labour, 37

Domestic work, 153

Drink, expenditure on, 235

Durham, agricultural wages, 148

Economic rent, 279

Education, 46

- as a ladder, 127

- expenditure on, 224, 240

- relation to manual labour, 130

Embroidery trade, 188

Employment, in production, 9

Engineor as Free Trader, 146

Engineering, production of, 4

England and Wales, origin of wealth, 96

- population, 96
Eversley, Lord, on agricultural population, 102

Exportation, 80

Exports, British, 222

- in 1907,7

Farmers under Protection, 272

Females engaged in production, 12,14

Finance of Tariff Reform, 253

Fiscal Policy, 196, 248-275

Fisher, Professor Irving, on capital, 84

Fisheries, production of, 5,6

Flax, production of, 5

Flux, A. W., classification of productive workers, 14

Fodder, imports of, 97

Food, cost of distribution, 78

- preserving, 187

- price of, 147, 205, 206

- production of, 4,5

- taxes, policy of, 268-273

Fox, Mr. Arthur Wilson, on agricultural earnings, 164

France, national expenditure, 229

- urban population, 100

Fraud, checks upon, 121

Free Trade, 196, 248-275

- effect on rent, 287

- meaning of, 146

Freedom, relation to work, 52

Freights, fall in, 212

- influence on prices, 146

Fruit, cost of distribution, 78

Frustration of production, 1, 39

Furniture, produetion of, 20

Gary, Judge, proposes State control of American iron trade, 63

Gas trade as natural monopoly, 65

George, Henry, 276, 294

Germany, national expenditure, 229

- urban population, 100

- wheat prices, 196

Giffen, Sir Robert, on national expenditure, 227

Girls engaged in production, 12, 14

Gladstone, promise to abolish Incomo Tax, 244 


\section{INDEX}

Glamorgan, rural wage, 148

Glass, exports of, 257

- imports of, 257

- Mr. Chamberlain on, 256

Gold, British imports, 210

- British stock of, 207

- relation to prices, 200

- world's output, 202, 210

- world's stock of, 208

Great State, The, 44 et seq.

Health, relation to land, 112

Herefordshire, agricultural earnings, 164

Hides, price of, 205

- production of, 5

Hollow-ware trade, 188

Home Work Committee, 175

Honesty, influence of commercialism, 121

Horses, production of, 5

Hours of labour, 52

Houses, cost of rebuilding Britain, 18

- production of, 16

- production per head of population, 17

Housing, 15

- land needed for, 113

- relation of capital, 118

Ideas, property in, 91

- source of wealth, 84

Import duties, Mr. Chamberlain's programme, 251

Importation, 80

Imports in 1907, 7

Income $\mathrm{Tax}$, assessments, 221

- on various incomes, 242

Index numbers of prices, 198, 205

Indiarubber, price of, 205

Industrial output, 3, 4

Industry, mutation of, 60

- relation of land, 109

Insurance, 224

Interest, 60

- approved by Henry George, 289,295

- in Canada, 120

Invention, 60

- relation to capital, 90

- relation to poverty, 37

Inventors, legal rights of, 91
Investing, 58

- in 1913, 235

Ireland, fiscal policy of, 266

Iron, exports of, 257

— imports of, 257

- Mr. Chamberlain on, 256

- price of, 205

- production of, 4

- stagnation in, 258

- trade in, 63,64

Italy, national expenditure, 229

Japan, low wages of, 155

Jute, price of, 205

Labour, division of, 37

Labour laws, effect on wages, 158

Lace trade, minimum wage in, 166

Lace-finishing, 177, 183

Ladder, Educational, 127

Lancashire, rural wages, 148

Land, amount needed for industry, 109

- economic definition, 93

- nationalisation, 117

- relation to British wealth, 93

- relation to capital, 119

- relation to health, 112

- relation to housing, 110

- relation to wealth, 278

- rent of, 279

- situation its fundamental at. tribute, 117

- tenure, 94

Land Taxes, 276, 296

Land Values, 279

- - revealed by Death Duties, 283

Lansdowne, Lord, quoted, 268

Laundry trade, 188, 189

Lead, price of, 205

Leather trades, production of, 4

Liberíy, in choice of profession, 50

- relation to work, 52

Linen-embroidery trade, 188

Living wage, 171

Local expenditure, 281

Locomotion, relation to housing, 113

London, as manufacturing centre, 26

Londo' Bankors' Clearanecs, 210

Luxury, growth of, 230, 235 
Machinery, as labour saver, 37

- waste of, 42

Males engaged in production, 12, 14

Mallon, Mr. James J. and the minimum wage, 175

Malthus, on population and wealth, 277

Manual labour, 53, 130

- workers, 11, 26

Manufactures, as materials, 261

- exports of, 257

- imports of, 257

- net output of, 4

- production of, 6

Manufacturing, organisation of, 43

- relation of land, 109

- relation to trade, 38

Marriago in Tho Great State, 61

Marshall, Professor, quoted, 246

Materials, 108

- difficulty of Tariff treatmont, 272

- used in British industry, 4

Ment, price of, 205

Menial servants, 59

Mental labour, 53

Mereantilism, 250

Motal trades, production of, 4

Milk, competition in supply of, 65

- cost of distribution, 78

Mill, John Stuart, on nationalisation of industry, 62

Milling, 73

Mineral oil, price of, 205

Mines, production of, 4,6

Minimuin standard of life, 5 l

Minimum wage, conferenco on, 166

- - in agriculture, 162

- - in prnetice, 174-194

- - physiological, 171

- - rates fixed under Trado Boards Act, 178

Mining, conscription for, 57

- minimum wago in, 170

- reward of, 28

Mobility of labour, 145

Money, in The Great State, 49

Mortgages under Single Tax, 288

Motherhood in The Great State, $6 \mathrm{I}$

Motor-cars, expenditure on, 235
Mutation of industries, 60

Mutton, cost of distribution, 78

- price of, 205

National Anti-Sweating Loague, work for minimum wage, 166, 175,181

National expenditure, 221, 224-230, 243-247

- - and economic stability, 241

- - compared with income, 226

- per head of population, 238

National Dividend, 8

Natural monopolies, 65

Navy, oxpendituro, 224, 231, 232,233

Newspapers, 32, 54

Non-producers, II, 25, 26

"North Western Miller" on wasto in milling, 74

Northamptonshire, rural wages, 148,164

Northumberland, agricultural earnings, 164

Nottingham lace trade, minimum wage in, 166

Officials of commerce, 25

Oil, prico of, 205

Old Ago Ponsions, 224, 227, 231

Organisation of work, 43

Output per worker, 13

Outworkers, 12

Oxfordshire, rural wagas, 148

Talm oil, price of, 205

Paper, production of, 4

Paraffin, price of, 205

Patent law, 91

Peaco, Retrenchment and Reform, 244

Personal property, 59

Physiocrats, 276

Pieco work, under Trade Boards Act, 179

Post Office, 68

- - expenditure, 224, 225

Poverty, of production, 1

- relation of science, 36

Preference, 248-275

Prices, effect of gold supply, 200-2 II

- explanation of rise, 211

- future of, 214 
Prices in 1871-1912, 198, 202

- index numbers, 198-205

- recent rise in, 195-215

- relation to wages, 146

- variation of, 204, 205

Printing, waste of, 31

Producers, enumeration of, 9, 11

Production, from ideas, 90

- frustration of, 1

- gross output, 3

- measurement in The Great State, 49

- net output, 3

- organic, 90

- organisation of, 43

- per worker, 13

- powers of, 90

- relation of machinery, 37

- simplicity of, 38

- value in 1907, 6

- value of, 4

- waste in, 29

Professional work, 51

Property, 59

Protection, 196, 248-275

Public utility services, production of, 4

Quesnay, on land and wealth, 276

Railway rates, 76

Railways, 42

- Act of 1913,159

- as capital, 86

- competition in, 66

- economy forced up, 67

- waste of, 74

Rates, amount of, 281

Raw materials, 108

- - difficulty of tariff treatment, 272

Rent compared with National Dividend, 282

- estimate of, 279

Retail profit, 40

Retailing, of carpet, 75

- of food, 78

- of wheat, 73

Rew, R. H., on decline of rural population, 104

Rice, price of, 205

Riches and Poverty, quoted, 228

Rubber, price of, 205
Rubbish, manufacture of, 34

Rural depopulation, 100-103

- wage, minimum, 162

- wages, 148

Russia, national expenditure, 229

Salaried persons, employed in production, 10

Saskatchewan, moneylending in, 120

Saving, 58

Science, relation to poverty, 36

- relation to production, $\mathbf{4 3}$

Scotland, agricultural employment, 102

Select Committeo on Trado Board Extension Act of 1913, 188

Selling, 38

Servile State, The, 48

Shipbuilding, production of, 4

Shirt making, 187, 191

Shop-keeping, gross profit, 40

Silk, exports of, 257

- imports of, 257

- Mr. Chamberlain on, 256

- price of, 205

Single Tax, examination of, 276-296

Slow workers under minimum wage, 186

Social Reform, expcnditure on, $224,228,231$

Socialism, 67

Soldiers of fortune, 44

Somersetshire, agricultural earnings, 164

South Wales' coalfield, 28

Steam laundries, 188, 189

Steamships, 42

Steel Trust of America, 63

Sugar, price of, 205

- trades, 187, 191

Surrey, rural wages, 148

Sweated Industries Exhibition, 175

Sweating, in Belfast, 192

- in confectionery trados, 190

- in laundries, 188

- in shirt making, 190

- minimum wage applied to, 174,194

Sweating Committec, 175 
Tailoring, 177, 178

Tariff Commission, proposal to tax Colonial food, 266

Tariff Reform, 196, 248-275

Taussig, Professor, on capital, 85

Taxation, effect of, 241, 247

- of land, 276

Tea, commerce in, 34

- price of, 205

Textile trades, production of, 4

Timber, 108

- price of, 205

- production of, 5

Timber trades, production of, 4

Tin, price of, 205, 206

Towns must be increased in area, 113

Trade Boards Act, 168, 174

Trade, boom of 1913, 223

- British, 248-275

- depression, accompanied national parsimony, 244

Transport, relation to housing, 113

Unemployment, Trade Unionist, 219

United Kingdom, basis of wealth, 96,263

- - trade of, 248-275

- - urban population, 100

United States, national expenditure, 229

- whoat distribution of, 70 , 71,72

United States Steel Corporation, 62

Urban population, growth of, 100

Van Hise, Professor, on folly of competition, 64

Vegetables, cost of distribution, 78

Victoria, Wages Boards of, 167

Wage carners, employed in production, 10

Wage, rolation to output, 75

Wages, agricultural, 137-145

- comparod with prices, 148
Wages, confectionery trades, 190,191

- effect of higher, 182

- effect of labour laws, 158

- efficiency of, 153

- embroidery, 190

- laundries, 189

- minima fixed under Trado Boards Act, 178

— on railways, 159

- relation to prices, 146

- relation to production, 13,14 , 15

- shirt making, 190

Wages Boards, chain making, $177-182$

- lace-finishing, 178, 182, 183

- nature of, 168-176

- of Victoria, 160

- paper-box making, 178, 184

- tailoring, 178

Warwickshire, agricultural earnings, 164

Waste, 29

Wealth, British basis of, 26

- British gain in materialwealth in 1907,6

- production per head, 7

- relation to land, 93

Wheat, imports from colonies, 254,255

- price of, 72, 146, 205

- wasto in distribution, 70,71 , 72,73

WiItshire, agricultural wages, 148

Women in The Great State, 61

Wood, price of, 205

Wool, Mr. Chamberlain on, 256

- price of, 205

- production of, 5

- waste in distribution, 79

Woollens, exports of, 257

- imports of, 257

Workers, number of available, 45

Yorkshiro, rural wages, 148

Zinc, price of, 205, 206 

UNIVERSITY OF CALIFORNIA, LOS ANGELES

THE UNIVERSITY LIBRARY

This book is DUE on the last date stamped below 
2326 Money -

N74f The future of work.
UC SOUTHERN REGIONAL LIBRARY FACILITY

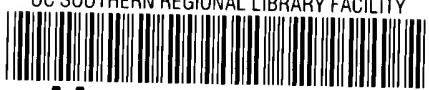

AA $000893714 \quad 6$

HD

2326

M74f 


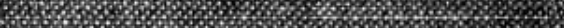

W

\%

7\%

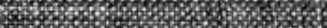

\% 